\title{
David Amram's Sonata for Piano: A merger of contemporary classical and jazz styles
}

\author{
Amanda Yuet Hwa Lee \\ West Virginia University
}

Follow this and additional works at: https://researchrepository.wvu.edu/etd

\section{Recommended Citation}

Lee, Amanda Yuet Hwa, "David Amram's Sonata for Piano: A merger of contemporary classical and jazz styles" (2006). Graduate Theses, Dissertations, and Problem Reports. 3444.

https://researchrepository.wvu.edu/etd/3444

This Dissertation is protected by copyright and/or related rights. It has been brought to you by the The Research Repository @ WVU with permission from the rights-holder(s). You are free to use this Dissertation in any way that is permitted by the copyright and related rights legislation that applies to your use. For other uses you must obtain permission from the rights-holder(s) directly, unless additional rights are indicated by a Creative Commons license in the record and/ or on the work itself. This Dissertation has been accepted for inclusion in WVU Graduate Theses, Dissertations, and Problem Reports collection by an authorized administrator of The Research Repository @ WVU.

For more information, please contact researchrepository@mail.wvu.edu. 


\section{DAVID AMRAM'S \\ SONATA FOR PIANO: \\ A MERGER OF CONTEMPORARY CLASSICAL AND JAZZ STYLES}

Amanda Yuet Hwa Lee

A Doctoral Research Project submitted to

The College of Creative Arts

at

West Virginia University

in partial fulfillment of the requirements for the degree of

Doctor of Musical Arts

in

Piano Performance

James Miltenberger, D.M.A., Chair

David Taddie, Ph.D., Research Advisor

Mary Ferer, Ph.D.

Ping Lee, Ph.D.

Janis-Rozena Peri, M.M.

Connie Arrau Sturm, Ph.D.

Division of Music

Morgantown, West Virginia

2006

Keywords: David Amram, Sonata for Piano, Third Stream, twentieth century piano works, jazz piano, theme and variations

Copyright 2006 Amanda Yuet Hwa Lee 


\title{
ABSTRACT \\ David Amram's Sonata for Piano: A Merger of Contemporary Classical and Jazz Styles
}

\begin{abstract}
Amanda Yuet Hwa Lee
Born in 1930 in Philadelphia, David Werner Amram III is among the most prolific composers in the United States. His published compositions encompass a wide variety of genres including orchestral and chamber works, operas, choral works, and works for solo instruments.

Written in 1960, Sonata for Piano, a three-movement sonata, is one of the most jazz-influenced piano sonatas written in the first six decades of the twentieth century. The sonata is an amalgamation of traditional western art forms and jazz idioms. This study provides an analysis of major musical elements (melodic and harmonic procedures, texture, rhythm, and performance considerations) that contribute to the overall structure and character of the sonata.

The research document also provides an overview of selected piano solo pieces of jazz influence written between 1900 and 1960. The major jazz elements found in these pieces may serve as a reference guide in determining the significance of Sonata for Piano. A short biography of the composer is included. The appendices contain Amram's comments from a telephone interview with the author and a list of published works by the composer. This document may serve as a resource for musicians and scholars who are interested in pursuing further studies of this work or other works of David Amram.
\end{abstract}




\section{Dedicated}

to

Caleb and my family 


\section{ACKNOWLEDGEMENTS}

I would like to sincerely and gratefully thank my major professor and chair of my doctoral committee, Dr. James Miltenberger, for his scholarly advice and encouragement throughout my undergraduate and graduate studies here at West Virginia University. This research document would not have been possible without the guidance and support of my research advisor, Dr. David Taddie, who patiently read my numerous revisions and never gave up on me. I would also like to thank all members of my doctoral committee, Dr. Mary Ferer, Dr. Ping Lee, Ms. Janis-Rozena Peri, and Dr. Connie Arrau Sturm, for their valuable input, expertise, and accessibility.

I would like to specially thank David Amram who kindly accepted the telephone interview and provided invaluable information in regard to Sonata for Piano. Finally, I would like to thank my family members and all my friends for their moral support and encouragement. 


\section{TABLE OF CONTENTS}

\section{CHAPTER}

I. INTRODUCTION.......................................................1

Purpose and Need for the Study...................................1

Limitations of the Study......................................

Research Design............................................3

II. SURVEY OF SELECTED SOLO PIANO PIECES WITH SIGNIFICANT JAZZ INFLUENCE WRITTEN FROM 1900 TO

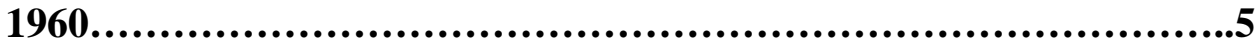

Methods of Survey.........................................5

Historical Overview........................................7

III. A SHORT BIOGRAPHY OF DAVID AMRAM......................25

IV. $\quad$ SONATA FOR PIANO ........................................41

First Movement: Overture.....................................42

Second Movement: Lullaby.................................49

Third Movement: Theme and Variations.........................60

V. CONCLUSION......................................................78

SELECTED BIBLIOGRAPHY............................................80

APPENDIX A - Telephone Interview with David Amram...................88

APPENDIX B - Published Compositions by David Amram.................101 


\section{CHAPTER I}

\section{INTRODUCTION}

\section{Purpose and Need for the Study}

Twentieth century solo piano music displays great diversity in the treatment of thematic ideas, tonal techniques, rhythmic complexities, textural contrasts, and sonority. There were composers who were greatly influenced by the folk arts and literature. Some composers chose to venture away from conventional tonality. However, some relied heavily on a more traditional harmonic approach in their writing.

Jazz has played such an important role in American vernacular music that it was inevitable that many classically oriented composers would draw upon it as a source of ideas in their own writing. One of the most well-known piano sonatas written by an American composer that incorporates jazz idioms is Aaron Copland's Piano Sonata, where jazz-like rhythms are infused in the development section of both the first and the second movements. ${ }^{1}$ Norman Della Joio’s piano sonatas also integrated “....syncopation borrowed from jazz idioms with a harmonic idiom based on seventh, ninth, and thirteenth chords, using traditional forms."2

In addition to piano sonatas, many character pieces that integrated jazz idioms cannot be neglected in today’s discussions on jazz-influenced pieces. George Gershwin’s Three Preludes and Aaron Copland's Four Piano Blues are two examples that contributed greatly to today’s standard piano literature.

\footnotetext{
${ }^{1}$ Stewart Gordon, A History of Keyboard Literature: Music for the Piano and Its Forerunners (New York: Schirmer Books, 1996), 514.

${ }^{2}$ Ibid., 520.
} 
David Amram's Sonata for Piano, a work cast in three movements, is one of the most jazz-influenced sonatas up to 1960 . This sonata exemplifies the integration of traditional western art forms with jazz idioms. The melodic and harmonic languages, as well as the rhythmic figurations, show a very significant influence of jazz traditions. Completed in 1960 and premiered by pianist, Andrew Heath, at the Grace Rainey Rogers Auditorium of the Metropolitan Museum of Arts in New York City, it is the only sonata written for solo piano by David Amram to date. ${ }^{3}$ The author has found little scholarly literature on the music of David Amram to date and none on the Sonata for Piano. According to David Amram, this is the first scholarly study of his Sonata for Piano. ${ }^{4}$ The purpose of this research is to discuss the significance and potential value of Amram's Sonata for Piano in today's standard repertoire. In order to fulfill the research goal, the author will investigate the formal design of each movement. The author will also examine important musical elements that reflect the integration of both classical and jazz idioms to facilitate intelligent performance decisions.

Given that each movement displays its own distinct style and character, the structural development of all three movements of the sonata, representative compositional techniques practiced by the composer in this sonata, and sources of inspiration as given by the composer will be addressed.

The title of each movement is as follows:

$$
\begin{gathered}
\text { First Movement - Overture } \\
\text { Second Movement - Lullaby } \\
\text { Third Movement - Theme and Variations }
\end{gathered}
$$

\footnotetext{
${ }^{3}$ David Amram, telephone interview by author, 5 April 2005, transcript.

${ }^{4}$ Ibid.
} 
David Amram, rooted in both classical and jazz traditions, uses a structure which combines both the classical forms of traditional Western art music, and the contemporary jazz characteristics of his time in Sonata for Piano. The author firmly believes that the work should not suffer from undeserved neglect and should be included in today's standard keyboard literature. This document may serve as a resource for future musicians and scholars who might be interested in pursuing further studies of this work or other works of David Amram.

\section{Limitation of the Study}

This study focuses on the formal design and structure, as well as performance practices of all three movements of the sonata. The study examines the major musical elements that contribute to the overall structure of the sonata. These musical elements include: melodic and harmonic procedures; texture; rhythm, and performance considerations. Exhaustive theoretical analysis is not the focal point of this research.

\section{$\underline{\text { Research Design }}$}

This document consists of five chapters. The second chapter presents methods of survey used in the research. That chapter is followed by a historical overview of selected piano solo pieces of jazz-influence found in today's standard repertoire. The study of these solo pieces contributed greatly to this research as the author examined important classical and jazz elements that might help in determining the significance of Sonata for Piano. 
Chapter three presents a short biography of David Amram. Important discussions include the composer's musical life and career, including musical association with some of the most influential classical and jazz musicians of his day. His musical compositions and published books, commissions, awards, significant performances of his works, recordings, and his continuing contributions to contemporary musical life will be included in the discussion.

Chapter four is an examination of the Sonata for Piano, taking each movement in turn. It begins with an analysis of the form and structure of the First Movement Overture. It is followed by a discussion on the overall formal design of the Second Movement - Lullaby. Since this movement is strongly influenced by the blues, the study investigates elements derived from the blues idiom. This chapter concludes with a stylistic and formal analysis of the Third movement - Theme and Variations. The discussion includes musical factors that connect and unite the theme and the variations.

Chapter five offers a conclusion drawn from the research. A transcription of the interview with David Amram is included in Appendix A. A list of published compositions by the composer is provided for reference in Appendix B. 


\section{CHAPTER II}

\section{Survey of Selected Solo Piano Pieces with Significant Jazz Influence Written From 1900 To 1960}

\section{Methods of Survey}

The author conducted a survey of selected solo piano pieces written in the first six decades of the twentieth century which others have suggested are jazz influenced and that have also found their way into today's standard repertoire. It is this author's hope that an examination of these significant jazz elements in the solo piano works of others will lead to a better understanding of the importance of Sonata for Piano.

Since there are many jazz-influenced compositions, the survey was limited to selected solo piano pieces composed between 1900 and 1960, the year in which Sonata for Piano (1960) was completed. A selected list of jazz-influenced pieces surveyed has been provided at the end of this chapter for reference.

The review of literature revealed extensive studies completed on jazz-influenced solo piano music written by Aaron Copland and George Gershwin. On the other hand, no scholarly study has been written on David Amram’s Sonata for Piano.

The important sources consulted include monographs, journal articles, newspaper articles, dictionaries, dissertations and theses, music scores, audio recordings, and web resources. An interview with David Amram has also been conducted by the author to obtain relevant information on the Sonata for Piano.

RILM Abstracts of Musical Literature and Grove Music Online were two of the main online databases used in this research. A third, WorldCat, which contains catalogs 
from more than twenty thousand libraries in the world, was also consulted. All these databases have provided substantial information on publications related to the topic.

Among the keywords used for the search in the databases are: David Amram, jazz, jazz sonata, American sonata, twentieth century solo piano works, blues, blue notes, blues scales, syncopation, ragtime, and jazz-influenced piano works.

In addition to the above mentioned databases, a review of the following sources was completed: American Music Studies: A Classified Bibliography of Master's Theses by James R. Heintze and The Music Index: A Subject-Author Guide to Music Periodical Literature. The Music Index served as an important reference to sources which are more than twenty years old and are not currently available online.

Sources consulted during the process of compilation of jazz-influenced solo piano pieces include: Music for the Piano by James Friskin and Irwin Freundlich, ${ }^{5}$ A History of Keyboard Literature: Music for the Piano and Its Forerunners by Stewart Gordon, ${ }^{6}$ Music for Piano: A Short History by F.E. Kirby, ${ }^{7}$ Traditional World Music Influences in Contemporary Solo Piano Literature: A Selected Bibliographic Survey and Review by Elizabeth C. Axford, ${ }^{8}$ and Guide to the Pianist's Repertoire by Maurice Hinson. ${ }^{9}$ In the telephone interview with David Amram concerning his Sonata for Piano, the composer clearly stated that,

“...a lot of the harmonies that I used and the idea of the harmonic styles were very much based upon the

\footnotetext{
5 James Friskin and Irwin Freundlich, Music for the Piano: A Handbook of Concert and Teaching Material from 1580 to 1952 (New York: Dover Publications, 1973).

${ }^{6}$ Steward Gordon, A History of Keyboard Literature: Music for the Piano and Its Forerunners (New York: Schirmer Books, 1996).

${ }^{7}$ F.E. Kirby, Music For Piano: A Short History (New Jersey: Amadeus Press, 1995).

${ }^{8}$ Elizabeth C. Axford, Traditional World Music Influences in Contemporary Solo Piano Literature: A Selected Bibliographic Survey and Review (Landham, M.D.: The Scarecrow Press, 1997).

${ }^{9}$ Maurice Hinson, Guide to the Pianist's Repertoire. Second, Revised, and Enlarged ed. (Bloomington \& Indianapolis: Indiana University Press, 1987).
} 
extraordinary and creative sophisticated music that was part of the musical language of the jazz community, which I was also very much a part of, having played with Charles Mingus, Dizzy Gillespie, Thelonious Monk, and Charlie Parker. A lot of those wonderful jazz artists who were really, I always thought, just like the great classical composers of the past."

Based on the above comment, the author also consulted original transcriptions by jazz musicians Thelonius Monk, Dizzie Gillespie, and Charlie Parker in order to trace important jazz figurations that might have been musical influences on Sonata for Piano.

\section{$\underline{\text { Historical Overview }}$}

There are a number of solo piano pieces written between 1900 and 1960 by otherwise traditional classical composers which others have suggested contain significant jazz influences. It is debatable how deeply these traditional composers were rooted in the tradition of jazz. It is also open to question as to how well these pieces have successfully synthesized both the classical and jazz idioms.

Jazz, which derives from the French word, “jasser,” can be generally translated as “to chatter.” The jazz orchestras in their earliest advertisements often spelled jazz as “jass.”11 “Jass” means "speeding up” in Creole. It is also a "four-letter word” commonly used in the New Orleans brothels. ${ }^{12}$

According to one of the past presidents of the National Association of Jazz Educators, Jack Wheaton, jazz can be described as “Afro-American music,” which combines "tribal African musical practices imposed on European form and harmony,

\footnotetext{
${ }^{10}$ David Amram, telephone interview by author, 5 April 2005, transcript.

${ }^{11}$ Jack Wheaton, “Jazz Piano Styles,” The Piano Quarterly 141 (Spring 1988): 18.

${ }^{12}$ Patricia Tupta and Marienne Uszler, “Jazz...From a Distance,” The Piano Quarterly 141 (Spring 1988): 12.
} 
performed (for the most part) on Western musical instruments." ${ }^{\text {"13 }}$ In his article titled, "Jazz Piano Styles," Wheaton presents what he considers to be the four most important African contributions to jazz:

1) Syncopation - accents fall on upbeats or weak beats

2) Improvisation - spontaneous playing over "preconceived tonal centers, chord progressions, form, tempo and style”

3) Rhythmic tension - the momentary delaying of melodic rhythm. The melody is often sound slightly behind the beat. This can also be associated with the late nineteenth and early twentieth century rubato style practiced by pianists such as Paderewski

4) Use of blue notes (lowered $3^{\text {rd }}, 5^{\text {th }}$, and $7^{\text {th }}$ of a major scale) in the melodic line against the diatonic $3^{\text {rd }}, 5^{\text {th }}$, and $7^{\text {th }}$ which occur in the harmony and bass lines. ${ }^{14}$ Of these, the first and fourth elements listed above are the two most common jazz characteristics found in many of the solo piano pieces of jazz-influence. In David Amram's Sonata for Piano, the use of syncopated rhythmic patterns, quasi-improvisatory passages (the most basic jazz ingredient), and blue notes are among the most significant jazz elements found. However, rhythmic tension found in this sonata is created between sections, as opposed to rhythmic tension which is created between the melody and the beat described by Wheaton.

Kirsten Joan Helgeland, in her dissertation titled, “Jazz and the Classics: A Study of American Crossover Solo Piano Works from 1920 to 1935," analyzes pieces by both classical and jazz/popular composers. Composers included were George Antheil, Bix

\footnotetext{
${ }^{13}$ Jack Wheaton, “Jazz Piano Styles,” The Piano Quarterly 141 (Spring 1988): 18.

${ }^{14}$ Ibid., 18.
} 
Beiderbecke, Hoagy Carmichael, John Alden Carpenter, Zez Confrey, Aaron Copland, George Gershwin, Ferde Grofé, Louis Gruenberg, and James P. Johnson. The term “crossing over,” as discussed by Heldgeland, implies borrowing musical elements from other music and incorporating them into the composer's musical vocabulary. ${ }^{15}$

According to Heldgeland, Ferde Grofé seemed to display little jazz influence in his solo compositions. Aaron Copland did create "jazz feeling” in his works; however, it ended as if it only contained moments of jazz rather than the style as a whole. Helgeland states that George Antheil only managed to display syncopations in his Jazz Sonata. She adds that the "atonality and the constantly shifting rhythms [in the Jazz Sonata] undermine any feeling of jazz the composer tried to create." ${ }^{\prime 16}$ She also believes that Gruenberg’s Six Jazz Epigrams “...has some superficial features of jazz, including syncopations, dotted rhythms, and blue notes. However, the musical language is clearly that of European concert music, and these six brief movements would not be mistaken for jazz." ${ }^{17}$

According to her research, the most significant melodic features found in the compositions that are jazz influenced are the employment of "blue" notes. The melodic shapes were influenced by the interaction between words and music practiced by the slaves in the fields. ${ }^{18}$ She also states that many composers chose to use syncopated rhythms as a basis for jazz rhythms. In addition, many of the pieces are cast in "ABA or rondo-like forms that are found in the salon music of the nineteenth century...Even those

\footnotetext{
${ }^{15}$ Kristen Joan Helgeland, "Jazz and the Classics: A Study of American Crossover Solo Piano Works from 1920 to 1935” (Ph.D. diss., University of Cincinnati, 1999), 282.

${ }^{16}$ Ibid., 284.

${ }^{17}$ Ibid., 278.

${ }^{18}$ Ibid., 282.
} 
pieces that are labeled 'blues' do not follow the twelve-bar blues form, but use the typical salon form instead." ${ }^{19}$

While many composers did not write music that would be considered pure jazz, they did successfully write in a style that appealed to the public. One of the many composers that Helgeland considers to have achieved excellence in combining jazz and classical music is George Gershwin. ${ }^{20}$

George Gershwin (1898 - 1937), being one of the most prominent American musical figures in the twentieth century, was in great demand as a composer and performer in the early 1920s. According to Robert Wyatt, the author of the article "The Seven Jazz Preludes of George Gershwin: A Historical Narrative,” Gershwin was well known for his fusion of classical music, jazz that he heard in Harlem, and popular music derived from the Tin Pan Alley, in his compositional approach. ${ }^{21}$

Wyatt highlighted, in the above mentioned article, an important historical event in which the Three Preludes were premiered. According to Wyatt's research, The Three Preludes were first performed by George Gershwin at the Hotel Roosevelt’s Grand Ballroom on December 4, 1926 at two-thirty in the afternoon. Gershwin performed a total of five preludes, from which, the well-known Three Preludes, were taken.

A combination of musical descriptions was drawn from reviews of the music critics who attended the recital. Among these music critics were F.D. Perkins, Samuel Chotzinoff, Abbe Niles, and Richard Stokes. These musical descriptions, which include

\footnotetext{
${ }^{19}$ Ibid., 282.

${ }^{20}$ Ibid., 283.

${ }^{21}$ Robert Wyatt, “The Seven Jazz Preludes of George Gershwin: A Historical Narrative,” American Music Vol. 7, no. 1 (Spring 1989): 70.
} 
some commonly used jazz terminologies, are listed below according to the performance order:

"Prelude 1 - vigorous, syncopated, jazz rhythm in the left hand [this became Prelude III of The Three Preludes] Prelude 2 - lyrical in vein resembling a nocturne, full of feeling [may be Prelude II of The Three Preludes] Prelude 3 - jazz melody with rolling Chopinesque bass Prelude 4 - in the blues tradition, languid, French postromantic in atmosphere, "blues" variety [may be Prelude II of The Three Preludes]

Prelude 5 - theme seemingly derived from the Rhapsody in Blue, basic rhythm of Spanish savor, Charleston for the left hand and a Spanish melody for the right [this became Prelude I of The Three Preludes],"22

Three of the five preludes listed above were "definitely the soon-to-be published Preludes for Piano” according to Isaac Goldberg (1887 - 1938), author of Gershwin’s biography titled, George Gershwin: A Study in American Music (1931). ${ }^{23}$ This biography was the first and only study of Gershwin's life published during the composer's lifetime. ${ }^{24}$ It was unfortunate that Goldberg did not identify which of the five preludes performed on that occasion corresponded to the three published ones. ${ }^{25}$

According to the musical descriptions written by the music critics, Prelude 1 performed in the concert came to be known as Prelude III in E-flat minor. The last of the five preludes was Prelude I in B-flat major. According to Wyatt, "Kay Swift stated that Gershwin referred to it as his Spanish prelude, and the rhythmic motif of the left hand is consistent with the reported Charleston accompaniment., ${ }^{26}$ Prelude II in C-sharp minor could be the second or the fourth piece in the program since both pieces contain "blues"

\footnotetext{
${ }^{22}$ Ibid., $80-82$.

${ }^{23}$ Ibid., 82, quoting Letter from George Gershwin to Isaac Goldberg, July 30, 1931, Issac Goldberg Collection, Pusey Library, Harvard University, Cambridge, Mass.

${ }^{24}$ Ibid., 73.

${ }^{25}$ Ibid., 83.

${ }^{26}$ Ibid., 82.
} 
melodies and are filled with flatted sevenths and thirds. The Three Preludes have "the distinction [of] being the only concert works published [in 1927] during Gershwin’s lifetime."27

In a pedagogical study titled "The Study of Representative Twentieth-Century Piano Compositions Appropriate for Use in Contemporary College Piano Literature Classes,” Keum Ju Bang presents a stylistic and interpretive analysis of four representative pieces of twentieth century piano literature, which he thinks are suitable to be used in contemporary college piano literature classes. Gershwin's Three Preludes is one of the set of pieces recommended by Bang. According to him, the Three Preludes contain important jazz elements such as syncopation in the bass lines, melodies that are often modeled upon blues songs, and many improvisatory passages. All of these elements can be traced in the First Prelude. The Second Prelude is filled with chromatic harmonic bass ostinatos, which can be associated with the traditional "walking bass" found in jazz. Folk-like melodies and “oom-pah” bass are evident in the Third Prelude. ${ }^{28}$

An important study on the piano music of Gershwin has also been conducted by Anthony C. LoBalbo. His dissertation, “A Performance Guide to Selected Piano Music of George Gershwin,” provides analysis of selected piano music of George Gershwin in order to offer a performance guide. ${ }^{29}$ LoBalbo’s study focuses on works by Gershwin which have not been edited, arranged, or adapted by another. Works included in the study were Rhapsody in Blue, Concerto in F, Preludes for Piano, Second Rhapsody, and

\footnotetext{
${ }^{27}$ Ibid., 68.

${ }^{28}$ Keum Ju Bang, “The Study of Representative Twentieth-Century Piano Compositions Appropriate for Use in Contemporary College Piano Literature Classes” (Ed.D. diss., Columbia University Teachers College, 1997), $121-122$.

${ }^{29}$ Anthony C. LoBalbo, “A Performance Guide to Selected Piano Music of George Gershwin,” Ph.D. diss., New York University, 1982).
} 
"I Got Rhythm" Variations. LoBalbo also includes discussion of pedaling issues. He quotes an excerpt from “Gershwin Years in Song,” in which Gershwin warned:

"Most pianists with a classical training fail lamentably in the playing of our ragtime or jazz because they use the pedaling of Chopin when interpreting the blues of Handy. The romantic touch is very good in a sentimental ballad, but in a tune of strict rhythm it is somewhat out of place." 30

LoBalbo concludes that Gershwin's Preludes for Piano are much more challenging musically and stylistically when compared to the work of Gershwin’s contemporaries. He adds that the novelty piano ${ }^{31}$ solos (Dizzy Fingers, Kitten on the Keys, and Coaxing the Piano) by such composer as Zez Confrey, require great technical skills and are generally musically entertaining; nonetheless, these pieces are "no match" to Gershwin's piano pieces in terms of melody, voicings, and the use of sustaining and middle pedals. ${ }^{32}$

He writes that Bix Beiderbecke’s In a Mist, which displays the style of stride piano, use of "blue" notes and scales, ninths, elevenths, and thirteenth chords, is closer to the jazz style of Gershwin. However, LoBalbo argues that the syncopations found in In a Mist are too complicated to be comprehended by audiences.

LoBalbo also contends that Aaron Copland's Four Piano Blues (published in 1949, twelve years after death of Gershwin), which incorporate "bluesy harmonies” and

\footnotetext{
${ }^{30}$ George Gershwin and Ira Gershwin. Gershwin Years in Song (New York: Quadrangle/The New York Times Book Company, 1973), 280.

${ }^{31}$ Novelty Piano: "A term, used particularly in the 1920s, that was applied to a variety of piano music based on ragtime. Novelty piano music drew on sources as diverse as popular dance music, folk ragtime and the music of the Impressionists (especially in its use of the whole-tone scale and the parallel 4th)." David Thomas Robert S/R, “Novelty Piano,” New Grove Music Online, 22 January 2006.

${ }^{32}$ Anthony C. LoBalbo, “A Performance Guide to Selected Piano Music of George Gershwin,” Ph.D. diss., New York University, 1982), 323 - 4.

${ }^{32}$ Ibid., 324.
} 
"bouncy rhythms" are pleasant pieces although the melodies are not as easy to remember. ${ }^{33}$

In the article "On the Influence of Jazz Rhythm in the Music of Aaron Copland" published in American Music, Stanley Kleppinger discusses the rhythmic materials commonly found in jazz-influenced works of Aaron Copland.

According to Kleppinger,

“Copland ...cite[s] a 1926 article by Don Knowlton which describes a musical practice Knowlton calls 'secondary rag'....Knowlton inherited the term 'secondary rag' from 'a Negro guitar player,' according to whom 'primary rag' refers to untied syncopation, while 'secondary rag' is the 'superimposition of one, two three upon the basic one, two, three, four. ${ }^{\text {"3 }}$

Figure 1 shows the expression of superimposition by Knowlton. ${ }^{35}$

\begin{tabular}{|llllllll|llllllll|}
1 & 2 & 3 & 1 & 2 & 3 & 1 & 2 & 3 & 1 & 2 & 3 & 1 & 2 & 3 & 1 \\
\hline 1 & & 2 & & 3 & & 4 & & 1 & & 2 & & 3 & & 4 &
\end{tabular}

Figure 1

Kleppinger states that among those jazz techniques that are exhibited in these pieces, which include Four Piano Blues and Piano Concerto, are the use of "blue notes" and the use of rhythms common in jazz. Jazz rhythm techniques, from Copland's perspective in the 1920s, “...can be summarized as the organization of melodic patterns

\footnotetext{
${ }^{34}$ Stanley V. Kleppinger, “On the Influence of Jazz Rhythm in the Music of Aaron Copland,” American Music Vol. 21, no. 1 (Spring 2003): 77.

35 Ibid., 77, quoting Don Knowlton, “The Anatomy of Jazz,” Harper’s 154 (April 1926): 581.
} 
to produce metrical strata that move in and out of phase with an unchanging, periodic, simple-meter accompaniment."36

Copland's Blues No. 2, originally composed in 1926, was published as one of the Four Piano Blues in 1949. Kleppinger states that the harmonic approach in this work exhibits the influence of Debussy more than that of jazz. However, syncopated rhythms and the $3+3+2$ rhythmic grouping of eighth-notes (refer to figure 1) evoked in this piece are particularly evidence of jazz influence. ${ }^{37}$

Many of the jazz rhythms and melodic techniques employed in Copland's output after 1930, such as “syncopation, superimposition of conflicting metrical strata, and varying metrical periodicity to preserve a melodic figure's metrical placement as it is transformed durationally," can also be found in the works of composers such as Stravinsky, Bartok, and Milhaud. Thus, Kleppinger suggests that the relationship between jazz techniques and some of Copland's later works is perhaps ambiguous. ${ }^{38}$ Kleppinger also refers to comments relating to Copland's use of jazz rhythm in books written on the life and works of the composer. The following are the comments made by several authors in reference to Copland's Piano Sonata, Second movement Vivace.

"The moods are alternatingly wistful and poetic, and, although the movement appears to be derived from jazz sources, no actual jazz themes are found”39

"The rhythms of this scherzo are striking; although the frequent changes of 5/8,6/8, 7/8 and other meters recall earlier scores, the beats fly by remarkably quickly, this

36 Ibid., $74-75$.

37 Ibid., 85.

38 Ibid., 99.

39 Ibid.,100, quoting Julia Smith, Aaron Copland His Work and Contribution to American music (New York: Oxford University Press, 1953), 232. 
"vivace" movement calling for the highest metronome marking possible. The resulting rhythmic vitality, while still related to jazz, seems derived as well from LatinAmerican music, which Copland heard much of while at work on the sonata." 40

"The second movement, marked Vivace, is a scherzo of mercurial lightness, with hints of jazz." 41

According to the above comments, each scholar finds a common ground by recognizing the influence of jazz in the second movement but no one was able to thoroughly trace or describe a jazz element applied in the composition of this movement. $^{42}$

John Lynch, in his thesis titled, “Emblems: Signifiers of Stylistic Coherence in the Formulation of an American Sound in This and Other Selected Works of Aaron Copland,” asserts that stylistic coherence has been achieved in Copland's works through the treatment of American themes and musical elements such as harmony, melody, rhythm, form, and timbre. The works included in the analysis are the opera The Tender Land, Four Piano Blues, orchestral work Inscape, and Emblems for wind band. Lynch contends that Copland's use of jazz idioms in his music can be compared to Mozart's, Stravinsky’s, or Bartok’s use of “indigeneous music” which reflects their cultures. ${ }^{43}$

It is this author's contention that Amram's Sonata for Piano similarly reflects one of the musical cultures of America, which is characterized by the fusion of the European tradition and the jazz idiom commonly practiced since the beginning of the twentieth century.

\footnotetext{
${ }^{40}$ Ibid.,100, quoting Howard Pollack, Aaron Copland: The Life and Work of An Uncommon Man (New York: Henry Holt, 1999), 353.

${ }^{41}$ Ibid., 100, quoting Neil Butterworth, The Music of Aaron Copland (London: Toccata Press, 1985), 85. ${ }^{42}$ Ibid., 100.

${ }^{43}$ John P. Lynch, "Emblems: Signifiers of Stylistic Coherence in the Formulation of an American Sound in This and Other Selected Works of Aaron Copland" (D.M.A. thesis, University of Cincinnati, 1996), $54-55$.
} 
According to Lynch, Blues No. 1 (1947) from Piano Four Blues features repeated minor thirds in the melodic line which evokes the singing of the blues. Sparsed twovoiced textures found in this piece also exemplify Copland's typical writing style. ${ }^{44}$ Blues No. 2 (1934) suggests the blues with the occurrences of major and minor thirds both in its harmony and melody. ${ }^{45}$ Blues No. 3 (1948) is the least connected to jazz. Blues No. 4 (1926) was written at the time Copland was composing the Piano Concerto. Again, "blue notes" (A-flat and E-flat) are frequently used as chord extensions in this F major movement (Blues No. 4). Blues No. 4 is also considered the most jazz influenced when compared to the first three blues. All four movements are cast in rounded-binary form. ${ }^{46}$ Lynch describes that "None [of the Four Piano Blues is] literally 'blues,' but rather a refined, subtle, and sophisticated distillation of the spirit of the blues." ${ }^{47}$ As for Amram's Sonata for Piano, the second movement, Lullaby, is no doubt filled with the spirit of the blues. The entire movement is heavily embedded with blue notes in both its harmony and melody. As suggested by the tempo indication (Andante e ben cantando) and the title, Lullaby, the piece evokes the singing of the blues.

Nelly Case provides a detailed, measure-by-measure analysis with emphasis on harmonic, rhythmic, thematic, and motivic features of Copland's four principal solo piano works, Variations, Sonata, Four Piano Blues, and Fantasy, in the dissertation "Stylistic Coherency In The Piano Works of Aaron Copland." focused on the composer's assimilation of serial technique in these works.

\footnotetext{
${ }^{44}$ Ibid., $55-6$.

${ }^{45}$ Ibid., 57.

${ }^{46}$ Ibid., $62-3$.

${ }^{47}$ Ibid., 54.

${ }^{48}$ Nelly Maude Case, “Stylistic Coherency in The Piano Works of Aaron Copland” (Ph.D. diss., Boston University, 1972).
} 
Case states that each one of the Four Piano Blues "reflects a specific idiom or mood derived from American music, rather than following any one traditional blues constructional format." ${ }^{49}$ The fourth blues, which is dedicated to John Kirkpatrick, serves as a preparatory study for the jazz-influenced Piano Concerto (1926). ${ }^{50}$

Elie Siegmeister (1909 - 1991), whose music synthesizes elements of jazz and folk, also contributed to the classical-jazz music of the twentieth century. Kenneth Bolton, who wrote a dissertation titled "The Solo Piano Music of Elie Siegmeister," states that "Elie Siegmeister...is a significant figure of that generation of native-born composers who defined American musical style in the $20^{\text {th }}$ century." ${ }^{\text {51 }}$

Bolton's dissertation encompasses the works from Siegmeister's early creative period (1928 - 48) and his mature period (1949 - 1987). "Strongly influenced by the works of Charles Ives, Siegmeister extended his own imaginative use of musical color and drama over virtually every instrumental and vocal genre. ${ }^{, 52}$ The works discussed from his early creative period include Theme and Variations No. 1, American Sonata, and the suite Sunday in Brooklyn. The works discussed from his mature period (1949 - 87) are Sonatas 2 through 7, Theme and Variations No. 2, and the suites On This Ground and From these Shores. Among the significant works written before 1960 that showed the influence of jazz are American Sonata (1944) and Sunday in Brooklyn (1946).

American Sonata was completed after he settled with his family in Brooklyn, New York. The composer in his notes states that, "[This sonata represents] an American

\footnotetext{
49 Ibid., 493.

${ }^{50}$ Ibid., 493.

${ }^{51}$ Kenneth Owen Boulton, “The Solo Piano Music of Elie Siegmeister” (D.M.A. diss., University of Maryland at College Park, 1997), Abstract.

52 Ibid., Abstract.
} 
panorama, blending jazzy and folk-like themes with purely classical form." ${ }^{\text {53 }}$ He also states that the jazz elements seen at the beginning of the sonata are characterized by the syncopated grouping of continuous eighth notes in the pattern of $3+3+2$ in both hands. ${ }^{54}$ The sonata is cast in three movements, with the first movement written in clear sonataallegro form. ${ }^{55}$

According to Bolton, Siegmeister’s Sunday in Brooklyn, a five-movement suite, “...range[s] from representations of quiet family moments to teeming crowd scenes...this work reflects various episodes of leisurely life in quite possibly America's most invigorating city in the mid-1940s." ${ }^{56}$ The opening of the first movement, "Prospect Park," strongly reflects the influence of George Gershwin with the "Sliding, chromatic harmonies underneath the melody." 57 The first theme of the second movement "Sunday Driver” is heavily filled with "off-beat accents and heavy syncopation.” In addition, there is an ongoing underlying eighth-note pulse in a division of $3+3+2$ rhythmic groupings. ${ }^{58}$ The fifth movement, "Coney Island" is also filled with a syncopated theme that is based on the $3+3+2$ rhythmic subdivision. ${ }^{59}$

William Hilborn presents a study of works by serious composers which show the use of the jazz idiom in his thesis, “A Discriminative Study on the Influence of Jazz on Serious Composers." Among the composers that were included in the discussion are Claudé Debussy, Igor Stravinsky, Darius Milhaud, Aaron Copland, Maurice Ravel, Kurt Weill, Erik Satie, William Walton, John Alden Carpenter, Bohuslav Martinu, and Rolf

\footnotetext{
${ }^{53}$ Ibid., Abstract.

${ }^{54}$ Ibid., 37.

${ }^{55}$ Ibid., 32.

${ }^{56}$ Ibid., 40.

${ }^{57}$ Ibid., 41.

${ }^{58}$ Ibid., 42.

${ }^{59}$ Ibid., 46.
} 
Liebermann. The study included both piano music and music composed for chamber ensemble and orchestra. ${ }^{60}$

Hilborn states that the use of syncopated eighth-note rhythm in Debussy’s Golliwogg's Cake Walk shows the influence of the cakewalks in American Minstrel shows. He thinks that this characteristic was one of the major elements which signifies the beginning of the jazz (pre-jazz) influence upon the compositions of major composers. $^{61}$

He contends that Stravinsky became interested in jazz while he was working on L'Histoire du Soldat in Switzerland in 1918. ${ }^{62}$ The Piano Rag Music (composed June 1919) is written in the style of ragtime. According to Hilborn, this work is probably considered the least successful of all of Stravkinsky’s jazz-influenced works. ${ }^{63}$

Hilborn also presents an interesting discussion of Milhaud’s La Creation Du Monde (The Creation of the World) - an orchestral work inspired by what the composer heard while in the theaters of Harlem. Considered the most jazz-influenced work by Milhaud, it is filled with blues-themes using intervals of minor thirds and minor sevenths, syncopated and rag-like rhythms, free rapid passages, and "tail-gate” glissandos by the trombone. ${ }^{64}$ David Amram was exposed to this work of Milhaud while studying at Oberlin Conservatory in 1948. Amram agreed that this composition was a marvelous work which fused jazz and classical music. However, he believes the composition was

\footnotetext{
${ }^{60}$ William Dean Hillborn, “A Discriminative Study on the Influence of Jazz on Serious Composers” (M.A. thesis, University of Missouri, 1962), Abstract.

${ }^{61}$ Ibid., $19-20$.

${ }^{62}$ Ibid., 21.

${ }^{63}$ Ibid., 27-8.

${ }^{64}$ Ibid., 35 - 37.
} 
not organic in its nature; instead, more of an attempt to embed one kind of music into another. $^{65}$

In Carol Yampolsky’s thesis, “The Solo Jazz Piano Music of Three American Composers: Armando “Chick” Corea [born 1941], William “Billy” Taylor [born 1921], Mary Lou Williams [1910 - 1981]: A Performance-Tape Project,” she discusses biographical information of the above mentioned composers, characteristics of their piano pieces, and the relationship of the music to the history of different keyboard styles.

Yampolsky states that,

"As jazz musicians, these composers are unusual in the sense that some of their keyboard works have been written out, following the procedure used in the traditional classical approach, as opposed to the typical jazz musicians practice of writing only sketches to be improvised upon during performance and perhaps transcribed from recordings into traditional notation at a later date." 66

She states that very few jazz composers actually adopted a traditional approach to composition, and in her opinion, these three composers "seemed to be the only American composer-performers of note to have contributed in this way."67

Yampolsky’s research documents Billy Taylor’s piano pieces composed from 1949 to 1959 . These pieces were divided into five major categories: ragtime, boogiewoogie, blues, swing, and bebop. ${ }^{68}$

Billy Taylor is an outstanding jazz musician and has performed with artists such as Lester Young, Dizzy Gillespie, Roy Eldridge, Lee Knotz, and Oscar Pettiford. He has

\footnotetext{
${ }^{65}$ David Amram, Vibrations: the Adventures and Musical Times of David Amram (New York: Thunder's Mouth Press, 2001), 63.

${ }^{66}$ Carol Jane Yampolsky, "The Solo Jazz Piano Music of Three American Composers: Armando "Chick" Corea, William "Billy” Taylor, Mary Lou Williams: A Performance-Tape Project” (D.M.A. diss., University of Maryland, 1986), Abstract.

${ }^{67}$ Ibid., Abstract.

${ }^{68}$ Ibid., 37 - 40.
} 
been heavily influenced by his contemporaries, as well as by previous generations. His overall compositional style for pieces written between 1949 and 1959 was well-blended with the bebop tradition of the forties and also common classical compositional elements of the twentieth century. ${ }^{69}$ Like Billy Taylor, David Amram has performed with jazz artists such as Dizzy Gillespie, Oscar Pettiford, and others who have notable achievements in the world of jazz. Also, Amram has been influenced by composers of the past, as well as his contemporaries (see Chapter 3 for details about Amram's musical career and influences).

Samuel Barber, who was one of the leading American musical figures of twentieth century music, also contributed greatly to music in the American idiom. In the dissertation, “Samuel Barber’s Works for Solo Piano,” James Philip Sifferman emphasizes the three elements which he thinks are prevalent in Barber's music. They are "the use of traditional formal structures coupled with great clarity within these forms, romantic expression, and incorporation of idioms found in American folk music and jazz. $^{70}$ The Sonata for Piano, Op. 26 (1950), reflects all three of these characteristics. Sifferman states that,

"The forms are traditional, as exemplified by the sonata-allegro of the first movement. Barber even makes use of the fugue in the fourth movement. The Sonata for Piano is most certainly romantic, as evidenced by its grand conception, its dramatic expression, and its chromatic harmonic language. American idioms appear in small doses, in the second and fourth movements. Examples of this include "blue notes" and the use of harmonizations and rhythms derived from American jazz.,"

\footnotetext{
${ }^{69}$ Ibid., 37.

${ }^{70}$ James Philip Sifferman, “Samuel Barber's Works for Solo Piano” (D.M.A. diss., The University of Texas at Austin, 1982), Introduction viii.

${ }^{71}$ Ibid., Introduction viii-ix.
} 
Barber's Excursions exhibits a more direct jazz influence than Piano Sonata, Op. 26. According to Sifferman, "One might even assume that these pieces reflect the flood of American patriotism prevalent at the end of World War II., ${ }^{, 2}$ The first Excursion is written in the style of a boogie-woogie; the second Excursion is based on the blues; the third is based on a folk melody which reflects a distinctive Latin flavor; the fourth is a country square dance.

The presence of "blue" notes is prominent in the first Excursion. " "The basic harmonic progression (I-IV-I-V-I) is strikingly similar to the typical 'blues' harmonic progression underlying the second of these Excursions: I-IV-I-V-IV-I., ${ }^{74}$

The most prominent jazz characteristics traced in the pieces discussed above are the incorporation of syncopated rhythms and blues notes. Unlike many of the solo pieces discussed, Sonata for Piano is a thorough synthesis of classical and jazz practices which contain syncopations and the use of blues notes, as well as improvisatory-like passages. While the sonata is heavily embedded with various jazz elements, it also retains the common form and structure practiced traditionally by many classical composers.

The following is a list of selected jazz-influenced solo piano pieces composed between 1900 and 1960 which were compiled from the survey. The list also includes some pieces not discussed above.

\begin{tabular}{lll} 
George Antheil & - & Jazz Sonata \\
Samuel Barber & - & Excursions, Piano Sonata Op. 26 \\
Bix Beiderbecke & - & In a Mist \\
\hline
\end{tabular}

\footnotetext{
${ }^{72}$ Ibid., 5.

${ }^{73}$ Ibid., 6 .

${ }^{74}$ Ibid., 9 .
} 


\begin{tabular}{|c|c|c|}
\hline Aaron Copland & - & Four Piano Blues, “Jazzy” from Three Moods \\
\hline Claude Debussy & - & Golliwogg’s Cake Walk \\
\hline George Gershwin & - & Three Preludes, Impromptu in Two Keys \\
\hline Morton Gould & - & Rag - Blues - Rag \\
\hline Ray Green & - & Festival Fugues (An American Toccata) \\
\hline Louis Gruenberg & - & $\begin{array}{l}\text { Polychromatics, Op. } 16 \text { (A Rag-Time Fragment), } \\
\text { Jazzberries, Op. } 25 \text { (I - Foxtrot, II - Blues, and IV - } \\
\text { Syncopep), Six Jazz Epigrams }\end{array}$ \\
\hline Ferde Grofé & - & Metropolis \\
\hline Paul Hindemith & - & Ubung in drei stucken \\
\hline Norman Della-Joio & - & All three piano sonatas \\
\hline Burrrill Phillips & - & Toccata, A Set of Three Informalities (I - Blues) \\
\hline Meyer Kupferman & - & $\begin{array}{l}\text { Sonata on Jazz Elements - } 12 \text { tone, jazz-classical } \\
\text { in classical sonata form }\end{array}$ \\
\hline Elie Siegmeister & - & $\begin{array}{l}\text { American Sonata, Sunday in Brooklyn (I - Prospect Park, } \\
\text { II - Sunday Driver, and V - Coney Island), Fantasy Rag }\end{array}$ \\
\hline Igor Stravinsky & - & Piano Rag Music \\
\hline \multicolumn{2}{|c|}{ William "Billy” Taylor - } & $\begin{array}{l}\text { a number of ragtimes, boogie-woogies, blues, swings, and } \\
\text { bebops }\end{array}$ \\
\hline Esther Williamson & - & Sonatina (II - Andante - free blues style) \\
\hline
\end{tabular}




\section{CHAPTER III}

\section{A SHORT BIOGRAPHY OF DAVID AMRAM}

David Werner Amram III was born on November 17, 1930, in Philadelphia, Pennsylvania. Active as a composer, conductor, and multi-instrumentalist, he has composed over one hundred works including chamber and orchestral works, two operas, and scores for films and theater. Amram plays French horn, piano, guitar, numerous flutes and whistles, percussion, and a variety of folk instruments from twenty-five countries. $^{75}$

Amram has written an autobiography of his own titled, Vibrations. It was published in 1968 and it was reissued in paperback by Thunder’s Mouth Press in 2001. The paperback edition also includes a forward by historian Douglas Brinkley. In Vibrations, Amram narrates his life experiences from childhood through 1967. Many of the significant musically related events mentioned in the book will be discussed in this chapter.

As the following accounts illustrate, classical, jazz, Latin American, as well as ethnic music have had a profound impact on Amram’s musical life. Classical and jazz influences, in particular, can be traced back to his childhood.

\footnotetext{
${ }^{75}$ David Amram, “The Biography of David Amram,” 2 February 2006

$<$ http://www.fmp.com/amram/AmramBiography.html>.
} 
His earliest exposure to classical music was hearing his father play the first movement of a Mozart sonata and a four-hand version of a Brahms symphony on the piano. $^{76}$

At age six, he received a bugle from his father, and his first thirty seconds of playing the bugle with relative ease initiated a lifelong addiction. A year later, he began taking piano lessons, as well as studying trumpet at the Music Settlement School in Philadelphia. $^{77}$

As a young boy (ca. 1938), Amram discovered jazz through radio broadcasts, when swing bands were most popular. In addition, he was informally taught gospel and blues songs by a man who worked on his family’s farm in Feasterville, Pennsylvania around 1939. He occasionally played trumpet with the man’s gospel groups. ${ }^{78}$

Amram took up the French horn as a way to replace the trumpet after he had braces put on his teeth around 1944. The French horn worked perfectly with his braces since that instrument has a smaller mouthpiece than the trumpet. ${ }^{79}$

In 1945, Amram was experimenting with composition and had already begun writing a trio for horn, violin, and piano based on the instrumentation of the Brahms Horn Trio. In the summer of 1946, he met with Dimitri Mitropoulos (the conductor of New York Philharmonic from 1949 - 1958). While spending some precious moments with the Maestro, he was given wonderful advice on ways to modulate and expand the harmony in his music that led him to restudy and rework his horn trio. ${ }^{80}$

\footnotetext{
${ }^{76}$ David Amram, Vibrations: the Adventures and Musical Times of David Amram (New York: Thunder's Mouth Press, 2001), 1.

${ }^{77}$ Ibid., 4 - 5.

${ }^{78}$ Ibid., 6.

${ }^{79}$ Ibid., 43.

${ }^{80}$ Ibid., 49.
} 
Upon the recommendation of his horn instructor, Van Lier Lanning, Amram began to study composition with Wendell Margrave in Washington D. C. in 1947. During lessons, Margrave would play works of Johann Sebastian Bach on the piano, pointing out subject and countersubject in order to help Amram understand the compositional process. His theoretical studies included Bach’s inventions. He also learned to analyze music and write canons and fugues. ${ }^{81}$

The same year, Amram was accepted at the Oberlin Conservatory, where he studied horn with Martin Morris. ${ }^{82}$ He chose to leave Oberlin in June of 1949 and moved back to Washington D. C. to study horn with William Klang from the National Symphony.

Amram enrolled at George Washington University in the fall of 1949, and during this time, he met musicians from all over Washington D. C. He would often invite them to jam sessions in his basement. They would play chamber music if they were classical musicians; otherwise, they would play jazz. ${ }^{83}$

Amram had already begun to play jazz using his French horn around 1949. He was considered a pioneer for bringing French horn into the jazz groups of this era. However, in order to further his classical training, he decided to study with Abe Kniaz, who was the newly appointed first horn for the National Symphony. In 1951, Amram became a part-time member of the symphony. ${ }^{84}$

While in Washington D.C., Amram met Charlie "Bird” Parker at one of Parker’s performances at the Howard Theatre. After the performance, "Bird” was invited to

\footnotetext{
${ }^{81}$ Ibid., 56.

${ }^{82}$ Ibid., 61.

${ }^{83}$ Ibid., 74.

${ }^{84}$ Ibid., 78 and 97.
} 
Amram’s basement to hear Amram’s group play. According to Amram, “Charlie Parker's whole concept of music, his dedication to it and the spirit he created, influenced [him] as a composer as much as any other musician that [he] can think of."85 Amram also met Dizzy Gillespie in 1952.

When Amram graduated from George Washington University in 1952, he was drafted into the United States Army. He was assigned to play French horn in the Seventh Army Symphony Orchestra in Germany. Later, while serving in the army at Camp Breckenridge in Kentucky, Amram met with Maceo Hampton, the cousin of the famous vibraphonist, Lionel Hampton. He has fond memories of the way Maceo showed him how to apply tonal harmony in his compositions.

According to Amram,

“...[he] was the first person to teach me what was then a new way of voicing simple chords, a system where the third and seventh are doubled so that someone who is not a pianist could play many complicated chord progressions and substitutions with a minimum of finger movements. With this extremely simple device, I was able to spend hours figuring out my own ways of voicing chords. ${ }^{, 86}$

Following his discharge from the army in 1955, Amram enrolled in the Manhattan School of Music in New York City. He studied horn with Gunther Schuller and composition with Ludmilla Ulehla and Vittorio Giannini. According to Amram, Giannini's passion was for “orchestral, symphonic, and operatic music” while Ulehla was an ardent theorist and was knowledgeable in twentieth century harmonic procedures. ${ }^{87}$

\footnotetext{
${ }^{85}$ Ibid., 106.

${ }^{86}$ Ibid., 115.

${ }^{87}$ Ibid., 221 - 22.
} 
Despite the differences in their teaching expertise, both of his composition teachers loved the music of J. S. Bach. ${ }^{88}$

While in New York in 1955, Amram was offered the opportunity to join the Jazz Workshop upon the recommendation of his friend, Leonard Feather. The Jazz Workshop was a newly formed jazz group led by Charles Mingus. ${ }^{89}$ Amram was the French hornist on the record entitled, Charles Mingus Quintet Live at the Café Bohemia with Max Roach (recorded in 1955). ${ }^{90}$

It was at the end of 1955 that Amram met Miles Davis, Lionel Hampton, and Thelonious Monk at the Bohemia Café where Mingus’s band played. Since his first meeting with Monk at the Bohemia, Amram began to have “... a series of after-school sessions with him.” They would spend time together listening to the radio and talking. Amram shared his compositions with Monk, who in turn, taught some of his own compositions to Amram. ${ }^{91}$

That same year, Amram was featured as the French horn soloist in a 1955 recording with Lionel Hampton entitled, Lionel Hampton in Paris: Crazy Hamp. He was also featured as one of the French horn soloists in Oscar Pettiford's band on recordings made in 1957 entitled, Oscar Pettiford’s Big Band, Volume 1 and Volume 2. Additionally, Amram's own jazz quartet (Amram - piano, George Barrow - Tenor Saxophone, Arthur Phipps - Bass, and Al Harewood - Percussion) auditioned with Decca Records. They successfully recorded with Decca Records in the spring of $1957 .{ }^{92}$

\footnotetext{
${ }^{88}$ David Amram, telephone interview by author, 5 April 2005, transcript.

89 David Amram, Vibrations: the Adventures and Musical Times of David Amram (New York: Thunder's Mouth Press, 2001), 219.

${ }^{90}$ Ibid., 483.

${ }^{91}$ Ibid., $223-27$.

92 Ibid., 248 and 264.
} 
In 1957, Amram played his first Jazz-Poetry Readings in New York City and collaborated with the famous American novelist and poet, Jack Kerouac, the same year. According to Amram, in Vibrations:

"Jack was a fantastic improviser, and when I was playing he would be able to make up words to go along with the music on the spot. He used his voice just like another horn, using words like notes...Sometimes I played jazz, sometimes classical music, mostly just music to fit the nature of each poem."93

In 1959, Amram completed the music for the documentary film, Pull My Daisy. The film was directed by Alfred Leslie and narrated by Jack Kerouac. In the film, Amram himself appeared as Mezz McGillicudy, a deranged French horn player. ${ }^{94}$

Amram continued to collaborate with Kerouac until the writer’s death in 1969. Amram’s collaboration experiences with Kerouac from 1956 to 1969 were documented in Amram's book titled Offbeat: Collaborating With Kerouac. The book was released in early 2002.

Besides being active in the world of traditional classical and jazz music, Amram has also been involved in theatrical music. He was invited by Stuart Vaughan, who was the artistic director of the New York Shakespeare Festival, to write music for all the plays for the summer season of 1957. Some of the plays for which he composed incidental music were Romeo and Juliet, Two Gentlemen of Verona, Macbeth, and Richard the Third. ${ }^{95}$ Amram was also invited to be the composer in residence and musical director of

\footnotetext{
${ }^{93}$ Ibid., 294 - 5.

${ }^{94}$ Ibid., 489.

${ }^{95}$ Ibid., $270-84$.
} 
the Phoenix Theatre in the fall of 1958. The first music that he wrote for the Phoenix Theatre was The Family Reunion. ${ }^{96}$

In 1959, Amram was awarded the Obie prize by The Village Voice for the 'best achievement for music off Broadway' in honor of his work with the Shakespeare Festival and the Phoenix Theatre. According to the composer, this was the very first award that he had received for any music that he had written. ${ }^{97}$

Among the other works completed by the composer in 1959 were: Shakespearean Concerto (written for two horns, oboe, and strings where jazz elements are incorporated in the third movement of the work), a violin sonata, Autobiography for Strings scored for string orchestra, and two theatrical works: The Beaux' Stratagem for the Phoenix Theatre, and The Rivalry. ${ }^{98}$

The year of 1960 seemed to be one of the most productive years in Amram's musical life. It was also the year when Sonata for Piano was written. On January 5, 1960, he had his Carnegie Hall debut for his Overture and Allego for accompanied flute. His music for Peer Gynt (incidental music to the play by Ibsen scored for two percussionists, violin, and three violas) was premiered on January 12th and his music for The Fifth Column (a television drama based on the Hemingway play), which was scored for full orchestra and recorded by CBS, was taped on January 29th. The drama was directed by John Frankenheimer and conducted by Amram himself. ${ }^{99}$

Andrew Heath, one of Amram's old friends, planned to give a piano recital in the fall of 1961 at the Metropolitan's Grace Rainey Rogers Auditorium. He wanted to know

\footnotetext{
${ }^{96}$ Ibid., 299 - 30.

${ }^{97}$ Ibid., 335.

${ }^{98}$ Ibid., 312.

${ }^{99}$ Ibid., 350.
} 
if Amram would write a piano sonata for the occasion. In response to this request, Amram said that he had previously made many sketches for piano music; however, most of them had landed in the wastebasket. Since he already had commitments for the year, he could only begin work on what was to become Sonata for Piano in July of $1960 .^{100}$

The Sonata for Piano is cast in three movements, each bearing a descriptive title Overture, Lullaby, and Theme and Variations. Overture is written in sonata form; Lullaby is based on blues; and Theme and Variations is based on a theme which Amram wrote in 1957 for a Shakespeare-in-the-Park production of Macbeth. The third movement consists of this theme and six variations. Jazz and classical traditions are interwoven in this sonata, reflecting the synthesis of the German-romantic European tradition with the American spirit.

The second and third movements of the piano sonata were later transcribed to a chamber work titled Conversations (1988). This work is written for flute, violin, viola, cello, and piano. It was commissioned by the Atlanta Chamber Players and funded by the Chamber Music America. It was premiered at Emory University’s Cannon Chapel in Atlanta on January 20, 1989. ${ }^{101}$ The first movement (Prologue) is cast in sonata form. The second movement (Lullaby) and the third movement (Theme and Variations) share the same titles with Sonata for Piano. Conversations was dedicated to each of Amram's children (Adira, Alana, and Adam) and "young people who enjoy the subtle beauty of chamber music."102

\footnotetext{
${ }^{100}$ Ibid., 355.

${ }^{101}$ Atlanta Chamber Players, Conversations: A $20^{\text {th }}$ Anniversary Salute to American Composers, produced by Paula Peace, excerpts from program notes, 66:47 min., ACA Digital Recording, CM20038, 1996, compact disc.

${ }^{102}$ Derrick Henry, "Musician Amram Shares His Passion for Music in 'Conversations'.” The Atlanta Journal and Constitution, 19 January 1989

$<$ http://www.fmp.com/amram/classical_reviews/conversations_1.html>.
} 
Toward the end of summer of 1960, Amram was asked to be the best man for his friend's wedding which was to take place in Marlboro, Vermont, at the end of the Marlboro Music Festival season. There, he met the famous concert pianist, Rudolf Serkin, who was the artistic director for the festival from 1952 to 1991. Amram promised to mail his piano sonata to Serkin when he completed it, and when Serkin received the mailed sonata a month after the premiere by Andrew Heath, he wrote back and invited Amram to be a guest composer at the Marlboro Music Festival for the summer of $1961 .^{103}$

At Marlboro, Jerry Tarack, on behalf of the Beaux Arts Quartet, asked Amram to write a string quartet which Amram simply titled String Quartet. The Beaux Arts Quartet performed his String Quartet at Town Hall in February 1962. After the completion of String Quartet, he wrote a piece for horn and cello entitled, “Three Songs for Marlboro." 104

Amram received additional theatrical commissions to be completed for the summer of 1960. Among the plays for which he wrote music were Henry V, Measure for Measure, and The Taming of the Shrew. ${ }^{105}$

He was also commissioned to write two film scores in 1960. These two film scores were The Young Savages and Splendor in the Grass. ${ }^{106}$ Two years later, Amram was invited by John Frankenheimer to go to California to work on the music for the movie The Manchurian Candidate. He worked on it towards the end of April, 1962, in Hollywood and took the opportunity to use contra-bass clarinets, hecklephones, three

\footnotetext{
${ }^{103}$ David Amram, Vibrations: the Adventures and Musical Times of David Amram (New York: Thunder's Mouth Press, 2001), 387 - 88.

${ }^{104}$ Ibid., 389.

${ }^{105}$ Ibid., 356.

${ }^{106}$ Ibid., 356 - 57.
} 
piccolos, bass flutes, a harpsichord, and many other instruments he had not used much prior to this. ${ }^{107}$ Amram's originality in diversifying orchestral colors by combining unusual instrumentations had set the standard for many of his later works.

In 1964, Amram entered another important phase in his career when he was commissioned by Wiley Hance of ABC television and Milton Krents of the Jewish Theological Seminary to write an opera based on a play by Reginald Rose called The Final Ingredient. According to Amram, "It was a story of a group of prisoners in a concentration camp who tried to break out in order to get an egg from the neck of a nearby tree. This egg was the final ingredient they would need for the illicit Passover service they were going to hold inside the camp." ${ }^{108}$ The opera was set in 1945, incorporated the frequent use of melodramatic overtones, and was performed by the $\mathrm{ABC}$ orchestra. ${ }^{109}$

Amram also worked on a cantata for chorus, orchestra, and soloists based on the works of American authors entitled, A Year in Our Land. The prologue is based on Another Country by James Baldwin, which describes the landscape of New York as the protagonist lands in a plane. The prologue was followed by four main sections and an epilogue. Spring in the East (the first section) was taken from John Dos Passos's Manhattan Transfer that describes 'a scene by a ferry’. In Summer in the West, text was selected from The Lonesome Traveler by Jack Kerouac “describing the mountains as the author sat in a shack at sunset." Fall in the North is "a description of the Wisconsin Dells during Thanksgiving,” extracted from Travels with Charley, by John Steinbeck. Winter in the South was taken from The Web and the Rock by Thomas Wolfe, which gives an

\footnotetext{
${ }^{107}$ Ibid., 399.

${ }^{108}$ Ibid., 416.

${ }^{109}$ Ibid., 438.
} 
account of "snow falling in the south." Amram concluded the work with selected texts from Walt Whitman’s Leaves of Grass. ${ }^{110}$

Amram was appointed by Leonard Bernstein, through the Rockfeller Foundation to become the first composer-in-residence of the New York Philharmonic in 1966 1967. ${ }^{111}$ Since his appointment with the Philharmonic, Amram has become one of the most acclaimed composers of his generation.

The following decades saw a rapid increase in the diversity of instrumentations and external cultural influences in Amram’s works. In 1970, Amram was commissioned by Leopold Stokowski’s American Symphony Orchestra to compose a concerto for jazz quintet and full orchestra. He completed the composition in three months and named it Triple Concerto for Woodwind, Brass, Jazz Quintet, and Orchestra. The work incorporates Middle-Eastern musical elements as the primary source of material for the third movement. He ventured even further by writing a solo flute part for his Pakistani flute. Other international influences include musical elements from Armenian and Egyptian cultures. The Triple Concerto was premiered at Lincoln Center on January 10, 1971 under the direction of the Japanese conductor, Kazu Akiyama. Six years later, in 1977, the third movement of the Triple Concerto was televised on a PBS Special with Amram's own jazz quintet performing with the Chicago Symphony Orchestra. On a different part of the same program, his quintet was joined by another world-renowned jazz musician, Dizzy Gillespie. ${ }^{112}$

\footnotetext{
${ }^{110}$ Ibid., $406-7$.

${ }^{111}$ Ibid., 452.

${ }^{112}$ David Werner Amram III, David Amram An Amercan Original, produced by David Amram and Stephen J. Epstein, Newport Classic, notes by David Amram, 1993, compact disc.
} 
That same year (1977), Amram was chosen to perform at the Historic First Concert by American Musicians in Havana, Cuba. A recording entitled Havana New York: The Historic U.S. - Cuban Musical Exchange of 1977 was made, and Amram was featured as a soloist on the piano, French horn, wooden flute, Spanish guitar, and percussion. ${ }^{113}$

As a goodwill ambassador for the State Department, Amram has also visited many countries around the world, from Brazil to Cuba, and from Kenya to Egypt. ${ }^{114} \mathrm{He}$ always returns from his excursions with numerous native musical instruments which he eventually incorporates in his own music. ${ }^{115}$ As a result, an assimilation of musical cultures that combines European classical, jazz, folk, and ethnic music can often be found in his compositions.

His Travels for Trumpet and Orchestra, which was premiered by the members of the Juilliard Orchestra on March 26, 1985, is cast in three movements. The work was commissioned by his friend, Mark Gould, and dedicated to Gould and his wife, Lora Lee. The principal theme of the first movement, "Taos" is based on a traditional melody called “The Moonlight Song,” which is sung as a romantic song at the Taos Pueblo in Northern New Mexico. The second theme is a traditional Southwest Native American social song that is also popular in Taos Pueblo. The second movement, Blues and Variations, incorporates the twelve-bar blues form, and the last movement, Taxim (a Middle-Eastern

\footnotetext{
${ }^{113}$ David Amram, Vibrations: the Adventures and Musical Times of David Amram (New York: Thunder's Mouth Press, 2001), 482.

${ }^{114}$ David Amram, “The Biography of David Amram,” 2 February 2005

$<$ http://www.fmp.com/amram/AmramBiography.html>.

${ }^{115}$ David Turner, “Johnny Jazz Seed,” 22 April 2005 <http://www.fmp.com/amram/jazz.lamont.html>.
} 
musical expression meaning to improvise with gusto) uses melodies originating from Tunisia. $^{116}$

Another published work by Amram titled American Dance Suite is a tribute to three musical cultures of America. They are "the Native American Cheyenne Nation of Plains People, the African- American blues masters of the South, and the Cajun style of Lousiana and East Texas.” It was premiered on October 18, 1986 by the Omaha Symphony. ${ }^{117}$

Amram's widespread knowledge and experiences with world music has led to the production of an educational documentary film entitled, Origins of Symphonic Instruments, featuring narration by the composer. In this 1990 documentary film, Amram demonstrates numerous folk instruments as being the roots of modern symphonic orchestral instruments. ${ }^{118}$

Amram is still very actively involved in various musical events and performances. He has appeared as Music Director for the past twenty-six years of the Brooklyn Philharmonic’s “Young People’s, Family, and Parks Concert Series.”119 He has also appeared as guest conductor-soloist with numerous major orchestras, including the Toronto, Indianapolis, Milwaukee, Kansas City, Baltimore, and Minneapolis Orchestras. He is also Music Director for the International Jewish Arts Festival, and since 1983, has been conducting the Metropolitan Opera Orchestra. ${ }^{120}$

\footnotetext{
${ }^{116}$ David Werner Amram III, David Amram: An Amercan Original, produced by David Amram and Stephen J. Epstein, Newport Classic, notes by David Amram, 1993, compact disc.

117 Ibid.

${ }^{118}$ David Amram, Vibrations: the Adventures and Musical Times of David Amram. (New York: Thunder's Mouth Press, 2001), 485.

${ }^{119}$ David Amram, "The Biography of David Amram,” 2 February 2005 $<$ http://www.fmp.com/amram/AmramBiography.html>.

${ }^{120}$ David Werner Amram III, David Amram: An Amercan Original, produced by David Amram and Stephen J. Epstein, Newport Classic, notes by David Amram, 1993, compact disc.
} 
In his eleventh Farm Aid appearance on September 18 of 2005, he performed with Willie Nelson. He also spent some social time with Neal Young, Dave Matthews, Emmy Lou Harris and other musicians as well as dedicated farm activists whom he usually sees once a year at this special event. ${ }^{121}$

On November 19, 2005, Amram Jam II was held in conjunction with his seventyfifth birthday celebration. It was held at the Tarrytown Theater in New York. The concert was to celebrate his music and his collaborations with artists from the worlds of music, theater, film, and literature since moving to New York in 1955. A portion of the proceeds from this concert was donated to the Jazz Foundation of America for Hurricane Katrina Relief Efforts for New Orleans and Gulf Coast area jazz musicians. ${ }^{122}$

Among the artists who performed on the first half of the program was classical saxophonist from the Boston Symphony, Kenneth Radnofsky, who performed a movement from Amram's saxophone concerto Ode to Lord Buckley. Metropolitan Opera violist Midhat Serbagi performed an instrumental excerpt from Amram's opera Twelfth Night with a libretto by Joe Papp. In celebrating Amram's work in the theaters and films, the concert also featured celebrity artists including actors John Ventimiglia (The Sopranos), Keir Dullea (2001), and Jerry Stiller, with whom Amram worked during the very first summer of the New York Shakespeare Festival in 1957. Prize winning author Joyce Johnson also recounted Amram's ground breaking collaborations with Jack Kerouac in 1957 at New York's first-ever jazz/poetry readings. The second half of the

\footnotetext{
${ }^{121}$ David Amram, 25 September 2005, email communication.

${ }^{122}$ David Amram, "The Homepage of David Amram at Home Around the World...composer/conductor/multi-instrumentalist, a living American treasure,” 10 January 2006 $<$ http://www.davidamram.com>.
} 
program featured musicians Paquito de Rivera, Jerry Dodgion, and Vic Juris in an all-star jam session of Amram's jazz, Latin, and World Music compositions. ${ }^{123}$

Amram received an honorary doctorate in 1979 from Moravian College in Bethlehem, Pennsylvania. ${ }^{124}$ Amram was honored by the Brooklyn Academy of Music as a pioneer of multicultural symphonic programming in spring of 1995 . He has been listed by BMI as “one of the Twenty Most Performed Composers of Concert Music in the United States since 1974.”125

One of his recent commissions includes a work written for chamber orchestra titled, A Little Rebellion: Thomas Jefferson. The work was premiered at the Kennedy Center by the National Symphony Orchestra. It was written for string orchestra, woodwind quintet and percussion. It was narrated by E.G. Marshall and conducted by Amram.

The composer's most recent work, Giants of the Night (a flute concerto), is dedicated to the memory of Charlie Parker, Jack Kerouac, and Dizzie Gillespie. The work was commissioned and premiered by Sir James Galway. Amram is currently working with Frank McCourt on a new setting of the Mass, Missa Manhattan, as well as on a symphony commissioned by the Guthrie Foundation, titled Symphonic Variations on a Song by Woody Guthrie. He is also in the process of completing his third book, Nine Lives of a Musical Cat. ${ }^{126}$

\footnotetext{
${ }^{123}$ Ibid.

${ }^{124}$ Gerald L. Bieritz, "The Songs of David Amram: A Representative Analysis and Review of Published Vocal Music for Accompanied and Unaccompanied Solo Voice," (D.M.A. diss., University of North Texas, 2001), 12.

${ }^{125}$ David Amram, “The Biography of David Amram,” 2 February 2005

$<$ http://www.fmp.com/amram/AmramBiography.html>.

${ }^{126}$ David Amram, 6 November 2005, email communication.
} 
Amram currently resides in Putnam Valley, New York where he owns a farm. He lives with his son on the family farm when they are not on tour. He continues to travel the world as a conductor, soloist, bandleader, visiting scholar, and narrator in five languages. $^{127}$

Today, David Amram is among the most prolific composers in the United States. He continues to produce compositions with great diversity in instrumentations, as well as richness in classical and jazz traditions, which often synthesize external cultural influences. His compositions are eclectic, original, highly crafted, and often embedded with a deep sense of emotional experiences. Amram's unrelenting spirit in seeking the beauty of music through his own expressions and an appreciation of others' cultural roots have made him one of the most highly admired composers in American society today.

${ }^{127}$ Ibid. 


\title{
CHAPTER IV
}

\section{SONATA FOR PIANO}

Composed in July 1960, Sonata for Piano is the only sonata written for solo piano to date by David Amram. It is one of the most jazz-influenced sonatas up to 1960. Jazz idioms are integrated into every movement of this classically structured work. Each of the three movements is titled:

\author{
First movement - Overture \\ Second movement - Lullaby \\ Third movement - Theme and Variations
}

According to Amram,

"I was thrilled to be commissioned to write a piece of absolute music. And I felt free to use some of the elements that I loved in the music I was surrounded by, which was seldom ever written down in a formal European compositional style, but rather improvised by genius musicians on the spot, to be heard one time only, unless someone recorded it at that moment. So for the Piano Sonata, I wrote an old-fashioned art for art's sake piece. And I always said that, especially in the case of the first movement, and in much of the second movement, and in one of the variations in the third movement, I used a lot of the harmonic procedures, phrasing, and polyrhythms that were part of the jazz world's aesthetic." "128

The following discussion is an examination of Sonata for Piano, taking each movement in turn. An analysis of the form and structure of each movement is discussed. Important melodic, harmonic, and rhythmic figurations that portray significant jazz and classical influences are addressed.

${ }^{128}$ David Amram, telephone interview by author, 5 April 2005, transcript. 


\section{First Movement: Overture}

Overture is in sonata-allegro form. Melodies based on blues scales are prominent from the beginning phrase to the close of this movement. However, harmonically, the movement does not settle into a key center as might be expected in a typical jazz piece. The rapid shifts of tonal center and chromatic voice-leading are more characteristic of late-romantic or early twentieth century than jazz of that period. The development of the thematic materials partakes of both classical motivic fragmentation/variation and jazz improvisation.

The form and structure of the Overture is as follows:

Exposition (mm. $1-36)$

Development (mm. $37-61)$

Recapitulation (mm. 62 -94)

The exposition begins with an immediate statement of Theme 1a (mm. 1 - 4; see Example 1). The opening $16^{\text {th }}$ note figuration serves as an embellishment which introduces Theme $1 a$ in measure 1 . The theme begins in $\mathrm{F}(\mathrm{m} .1)$ but undergoes immediate shift to D-flat (m. 2), then progressing to B-flat (m. 4), forming a tertian relationship within the phrase. Measures 1 and 2 show accented chordal anticipations typical of jazz harmonic rhythm. 
Example 1: Overture, Theme $1 a$ (mm. 1 - 4), Theme $1 b$ (mm. 5 - 8). Copyright (C) 1965 by C.F. Peters Corporation. All Rights Reserved. Used by permission.

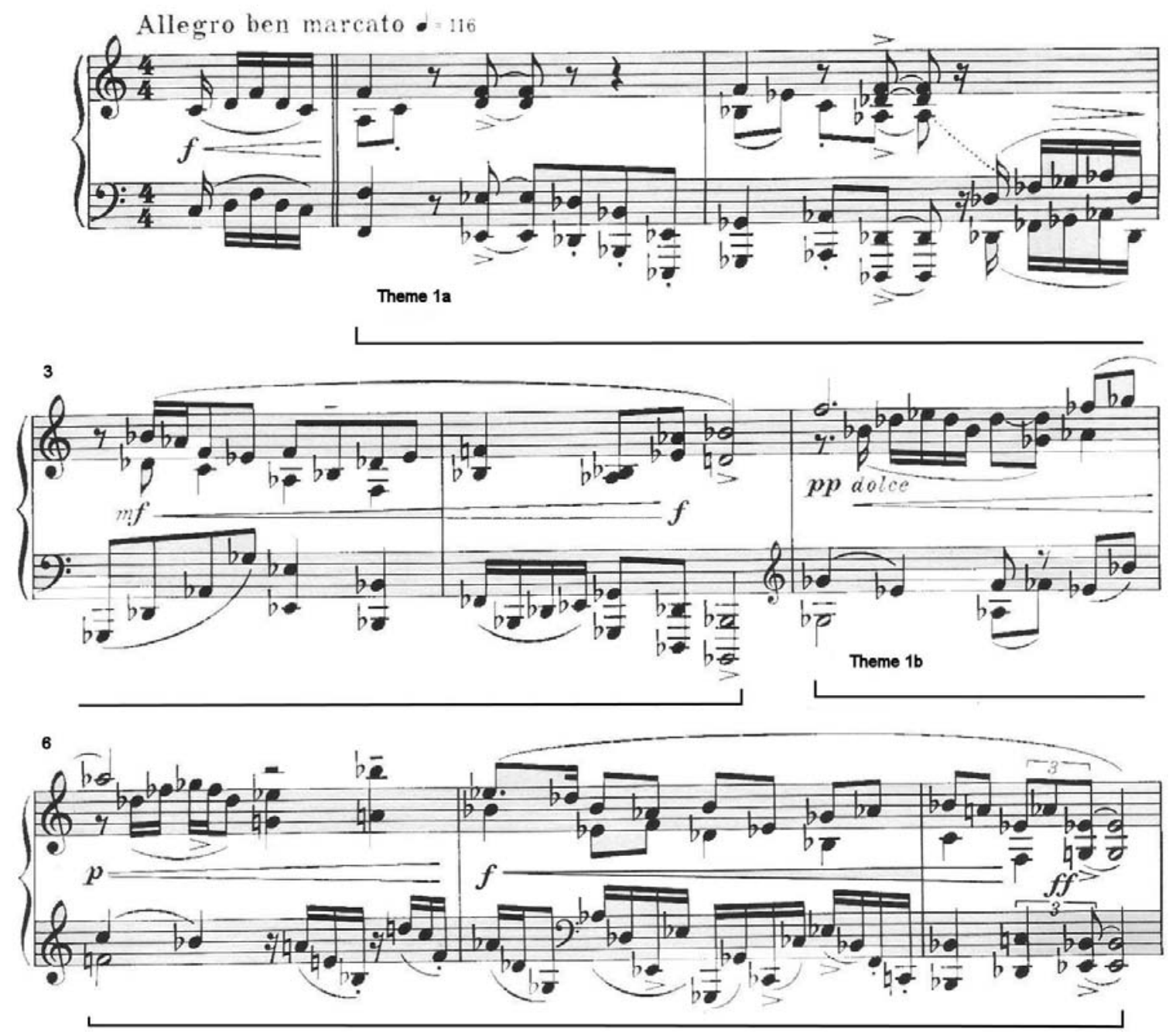

Theme $1 b(\mathrm{~mm} .5-8)$ is four measures long, generating a symmetrical period with Theme $1 a$. While Theme $1 a$ ends in B-flat, Theme $1 b$ begins in G-flat; thus, a tertian relationship is established between thematic phrases. The subito pianissimo helps to mark the beginning of Theme $1 b$, which presents textural contrasts (mm. $5-6)$ to Theme $1 a$ followed by a thematic variation $(\mathrm{mm} .7-8)$ of the second half of Theme $1 a$. Theme $1 b$ continues to build dynamically to fortissimo as it leads to closure of Theme $1 b$. The 
melodic line in mm. 3 - 4 and its variation (mm. 7 - 8) both reflect the employment of Bflat and E-flat blues scales respectively.

Measures 9-12 are a variation of Theme 1a. It begins a perfect fourth higher than Theme 1a. The B-flat blues melody that appears in the top voice of measure 11 is clearly derived from Theme $1 a(\mathrm{~mm} .3-4)$ melodically while showing rhythmic characteristics of Theme $1 b(\mathrm{~mm} .7-8)$. A fragment of the circle progression can be seen in measure 12 . The cadence is marked by a strong ii $-\mathrm{V}-\mathrm{I}$ progression in $\mathrm{D}$-flat.

Measures $13-18$ are a variation of Theme $1 b$. Measures $13-14$ are transposed three semitones from measures $5-6$ (another tertian relationship). The thematic materials in measures $15-16$ form something of a textural and rhythmic contrast to Theme $1 b$ (mm. 7 - 8). Compared to the 4-measure symmetrical phrase of Theme $1 b$, the two additional measures $(\mathrm{mm} .17-18)$ become an extension of the regular phrase length and also a further development of the blues melody. The momentary return of the opening phrase of Theme $1 a$ in measures 19 - 22 prepares the transition.

An interesting syncopated rhythmic embellishment that occurs in measures 22 (later m. 25) strongly resembles common rhythmic figurations used in jazz (see Example 2). Indeed, the whole of measures $22-26$ is infused with characteristic of jazz syncopations. The jazz-like rhythmic activity throughout measures $1-22$ keeps up the intensity and energy in this exposition. 
Example 2: Overture, mm. 21 - 26. Copyright (C) 1965 by C.F. Peters Corporation. All Rights Reserved. Used by permission.
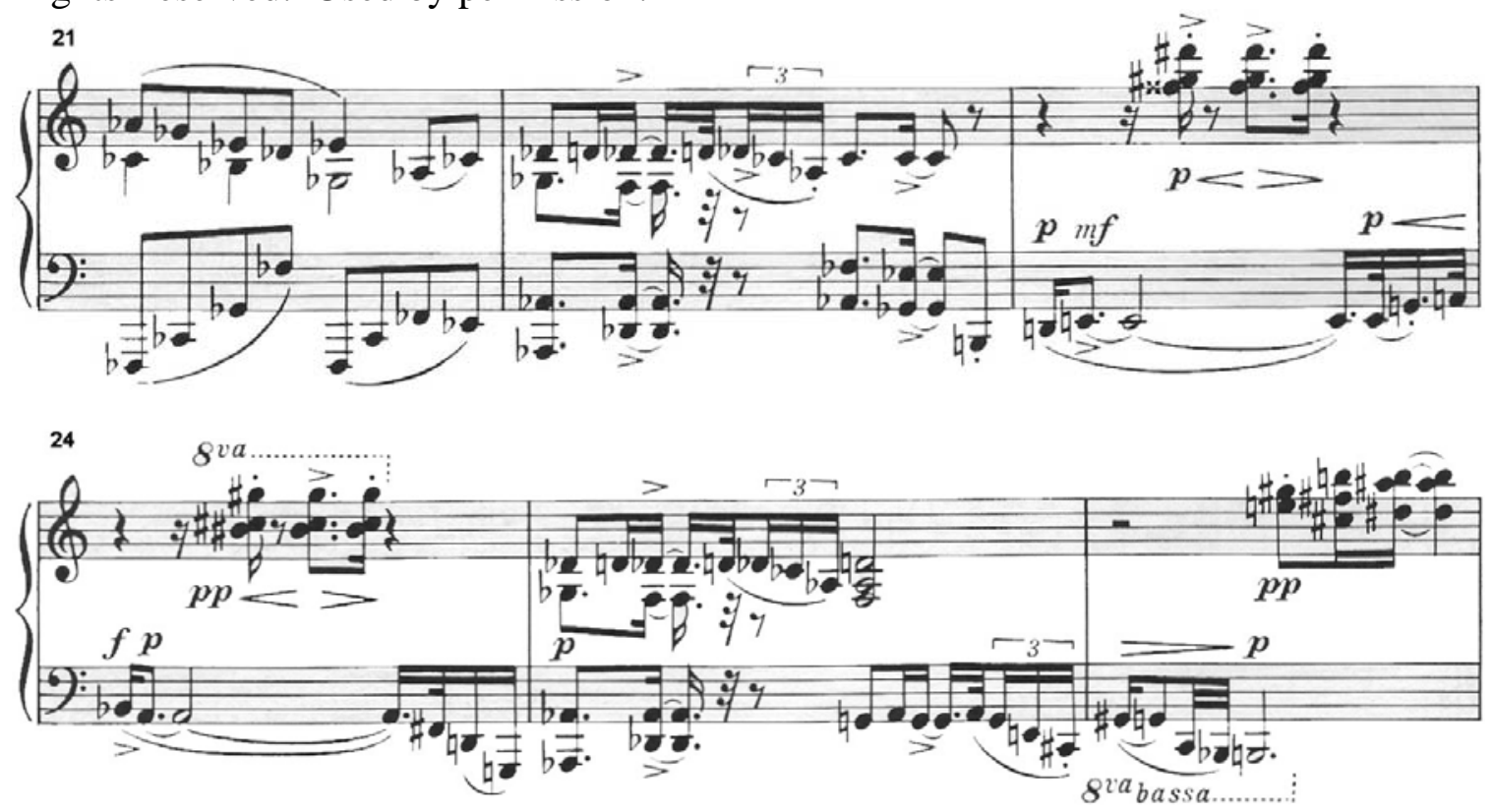

Transition 1 (mm. 23 - 30) connects Themes $1 a / 1 b$ to Theme 2. Transition 1 closes with a plagal motion to D-flat. D-flat becomes the long range structural dominant of this movement.

Theme 2 (mm. 31 - 36) lasts six measures (Example 3). The beginning melodic line of Theme 2 expressed by the ascending thematic pattern generates a sense of longing. The asymmetrical time-signature (7/4) brings metrical shifts of the melodic motion (whose flow should not be disrupted in performance). Theme 2 gives a maximal contrast to Theme $1 a / 1 b$ in tempo, meter, and texture while maintaining a blues-like character but in a slower tempo. The prolonged D-flat pedal point preceded by the bass octave G-flat (m. 33) closes the exposition and presents the structural dominant. The D-flat dominant pedal is left unresolved as the tritone motion to $\mathrm{G}$ forms the opening of the development. 
Example 3: Overture, Theme 2, mm. 31 - 34. Copyright (C) 1965 by C.F. Peters Corporation. All Rights Reserved. Used by permission.

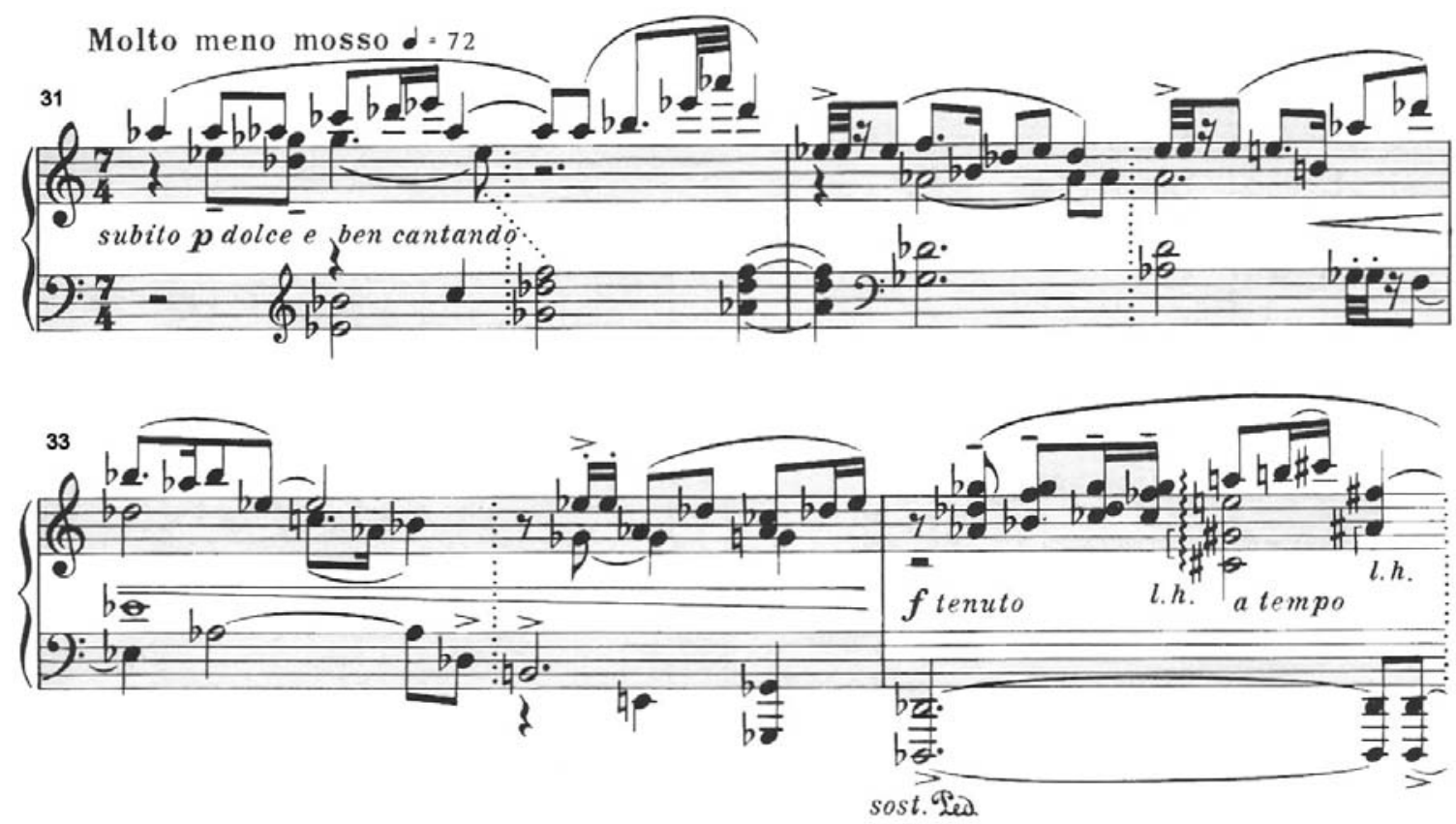

The $16^{\text {th }}$ note passage at the end of measure 36 increases the rhythmic activitiy which despite the rallentando, helps lead the music forward into the development section. Like the typical development of a classical sonata, Themes $1 a, 1 b$, and 2 can be traced in fragmented form throughout with rapid harmonic shifts.

The development section consists of jazz-like improvisations of the thematic materials though the rapid harmonic shifts and the thematic fragmentations are characteristic of traditional development sections. Measure 45 consists of a rapid arpeggiation of extended chords, adding color and depth to the passages. Measures 47 48 are filled with striving alternating octaves which resemble a boogie-woogie rhythmic bass pattern. 
The D-flat structural dominant pedal that occurs in Theme 2 of the exposition is once again stated in the development (mm. 52 - 55). Over the dominant pedal are free developments of the opening fragments of Theme 2 followed by fragments of Theme $1 a$. This D-flat pedal intensifies the tension of dominant - tonic relationship that is left unresolved in the development.

As is commonly practiced in the typical classical sonata-allegro form, the first part of the recapitulation (mm. 62 - 69) presents the same materials as in the exposition (mm. 1 - 8). Measures $70-79$ are exact repetitions of measures $13-22$ but transposed a minor second lower. There is only a brief two-measure transitional passage (mm. $80-82)$ as opposed to the eight-measure transition in the exposition. This transition is also written a minor second lower than in the exposition.

Theme 2 returns momentarily in F-sharp (enharmonic to G-flat) in measure 82, a whole-step lower than Theme 2 in the exposition (Example 4, also see Amram's comments concerning transposition of a major 2nd in Appendix A). The opening fragment of Theme $1 a$ is recalled in measure 87 in G-flat. The cadential motion of B - Csharp (enharmonically C-flat - D-flat) to G-flat (measures 89 - 90) carries the music to its final tonic and resolution of the structural dominant D-flat. The tonic (G-flat) is then prolonged for the next four measures, with motivic fragments articulating the other chord tones.

The B-flat major chord stated in measures 93 - 94 above the G-flat pedal, results in a polychordal effect above the tonic not uncommon in the closure of jazz pieces. The B-flat not only strengthens the tertian relationship with the tonic, it also foreshadows the opening key (B-flat) of the second movement. 
Example 4: Overture, mm. 82 - 94. Copyright (C) 1965 by C.F. Peters Corporation. All Rights Reserved. Used by permission.
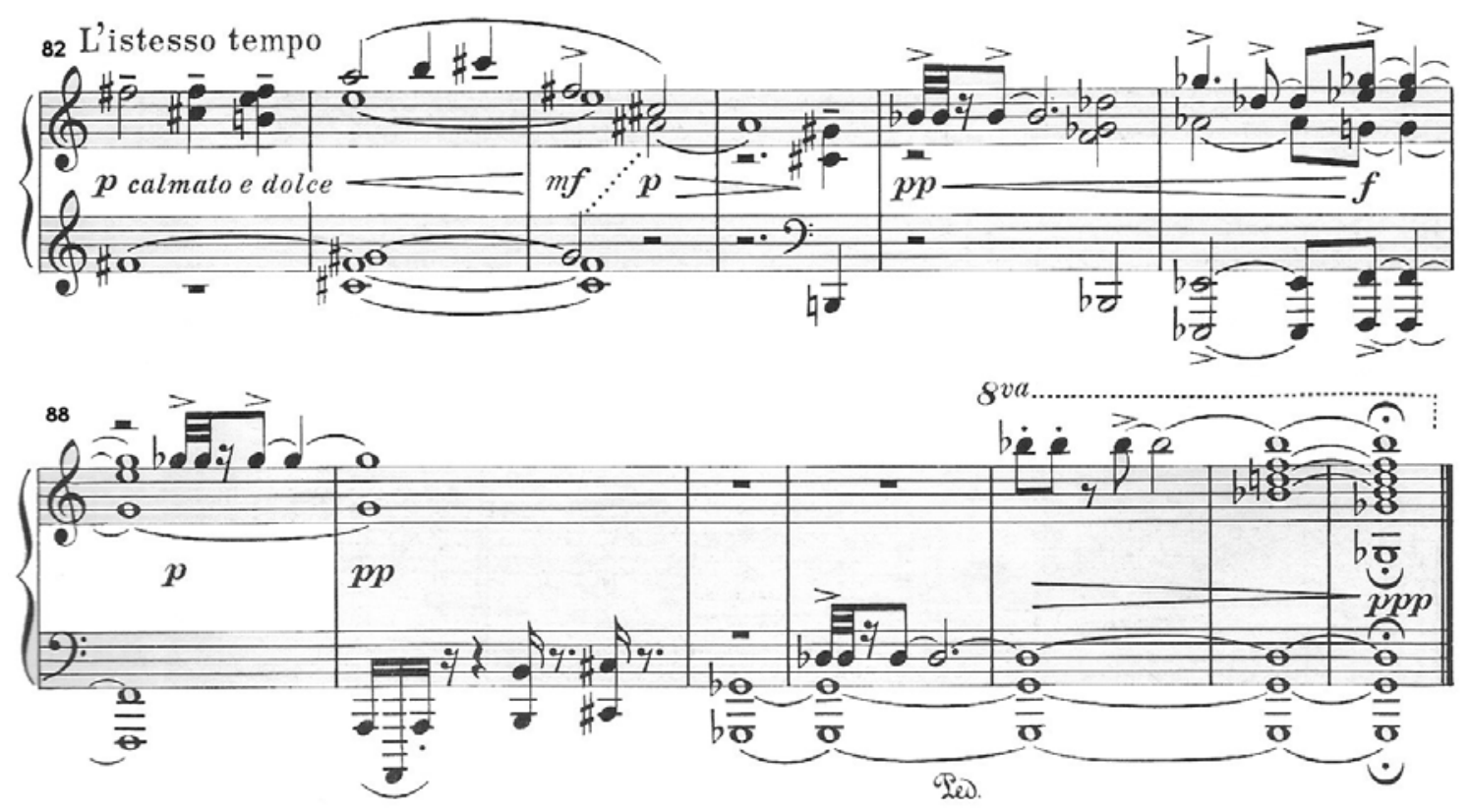

In summary, Overture is written in sonata-allegro form with clear thematic presentations in the exposition, development, and the recapitulation. Maximal contrast between thematic materials is achieved through change of texture, rhythm, and musical character.

Although the larger sections are not marked by strong cadences, the conflict of keys is resolved from a broader perspective. The closure of the exposition is supported by a prolonged D-flat pedal point. In the development, the D-flat pedal point is restated while thematic materials are developed. The tension of the two pedal D-flats intensifies the dominant preparation of G-flat which is only resolved through a dominant - tonic progression in measure 90. Despite the structural dominant - tonic relationship, tertian relationships are more prevalent within thematic developments. 


\section{Second Movement: Lullaby}

The second movement is a blues lullaby. Although it is not based on a typical blues progressions ( $-\mathrm{IV}-\mathrm{I}-\mathrm{V}-\mathrm{IV}-\mathrm{I})$, the chromatic inflections of the melody and the overall character reflect much of the blues spirit. This movement is written in the typical simple triple meter of a slow lullaby.

The tonality may seem obscure in this movement; nevertheless, a succession of tonal centers derived from the blues scales often helps to define the important key areas. In addition, traditional cadences such as perfect and imperfect authentic cadences which suggest strong tonal goals can be traced in the closure of phrases and sections.

The following is an outline of the form and structure of the second movement:

$$
\text { Section A - Section A’ - Transition } 1
$$

Section B

Section $1 / 2$ A - Transition 2 - Section A - Coda

\section{Section A (mm. 1 - 16)}

Lullaby is made up of two main themes - Theme $a$ and Theme $b$. Theme $a$ is eight measures long (mm. $1-8)$ and is made up of two symmetrical phrases, which in turn can be divided into Theme $1 a(\mathrm{~mm} .1-4)$ and Theme $1 b(\mathrm{~mm} .5-8)$. Theme 2 is also eight measures long (mm. 9 - 16) and is made up of two asymmetrical phrases - Theme $2 a$ (mm. 9 - 11) and Theme $2 b$ (mm. $12-16)$. 
Example 5: Lullaby, Theme $1 a$ (mm. 1 - 4), Theme $1 b$ (mm. 5 - 8). Copyright $@ 1965$ by C.F. Peters Corporation. All Rights Reserved. Used by permission.
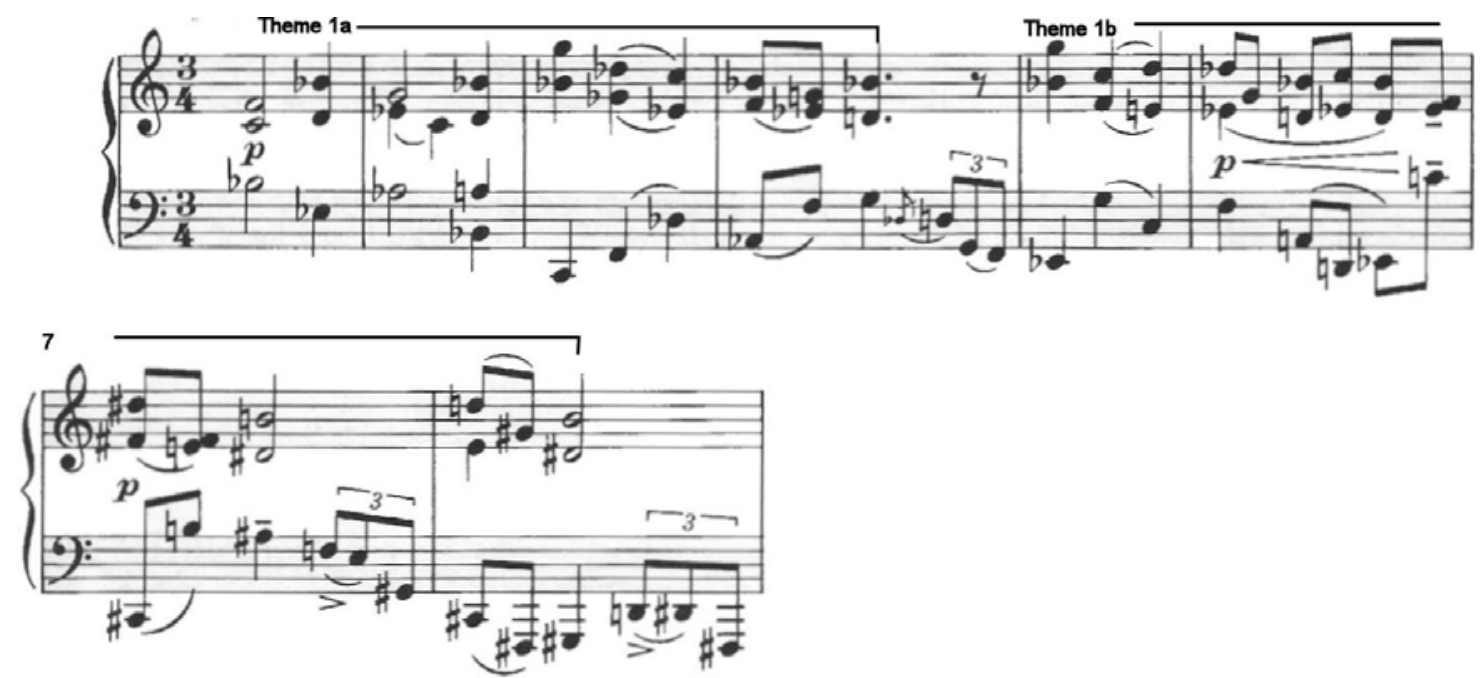

Theme $1 a(\mathrm{~mm} .1-4)$ is derived from the B-flat blues scale, supported by the presence of D-flat (lowered $3^{\text {rd }}$ ) and A-flat (lowered $7^{\text {th }}$ ) in measures 2 and 3 (Example 5). Theme $1 a$ departs from tonic (B-flat) through the progression of $\mathrm{I}-\mathrm{ii}-\mathrm{V}$, which leads to a deceptive cadence in measure 4 (Example 6).

Example 6: Lullaby, harmonic progression, mm. $1-8$. Copyright $(1) 1965$ by C.F. Peters Corporation. All Rights Reserved. Used by permission.

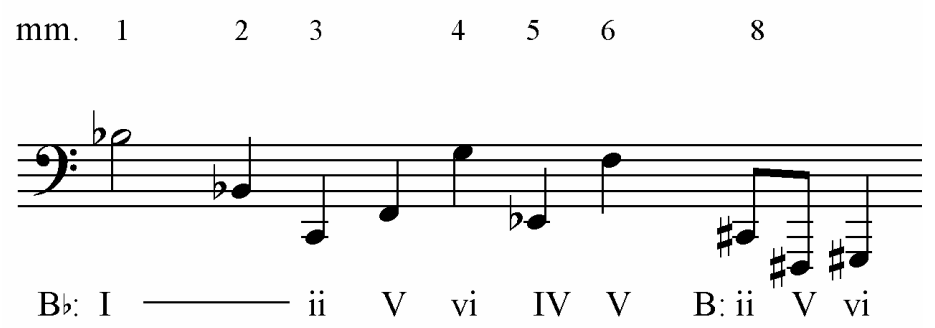


Theme $1 b(\mathrm{~mm} .5-8)$ is marked by the subdominant of B-flat major in measure 5 , leading to the dominant in measure 6 . In measure 7 , an abrupt modification of accidentals leads to a half-step modulation from a tonal center of B-flat to B (Example 5). The change of tonal center is supported by the enharmonic spelling of E-flat ( $4^{\text {th }}$ scale degree of tonal center B-flat) to D-sharp ( $3^{\text {rd }}$ scale degree of tonal center B), in addition to the occurrences of F-sharp and C-sharp that are both diatonic to tonal center B. The B tonal center is further supported by the progression ii - V - vi (deceptive cadence) in measure 8 (Example 6).

There is a significant melodic motive (motive $x$ ) that is consistently repeated either in its original or varied form throughout this movement. First seen in measure 6 of Theme $1 b$, this melodic motive is made up of a three-note figure: minor third, followed by a major second (Example 7).

Example 7: Lullaby, motive x, m. 6. Copyright $\left(C_{1} 1965\right.$ by C.F. Peters Corporation. All Rights Reserved. Used by permission.

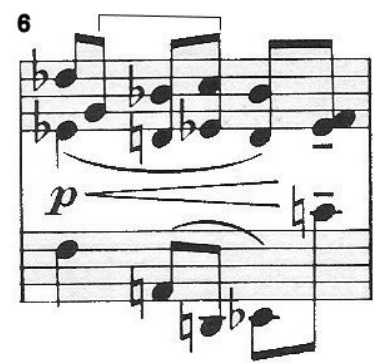


Example 8: Lullaby, Theme 2a (mm. 9-11), Theme $2 b$ (mm. 12-16). Copyright (C) 1965 by C.F. Peters Corporation. All Rights Reserved. Used by permission.
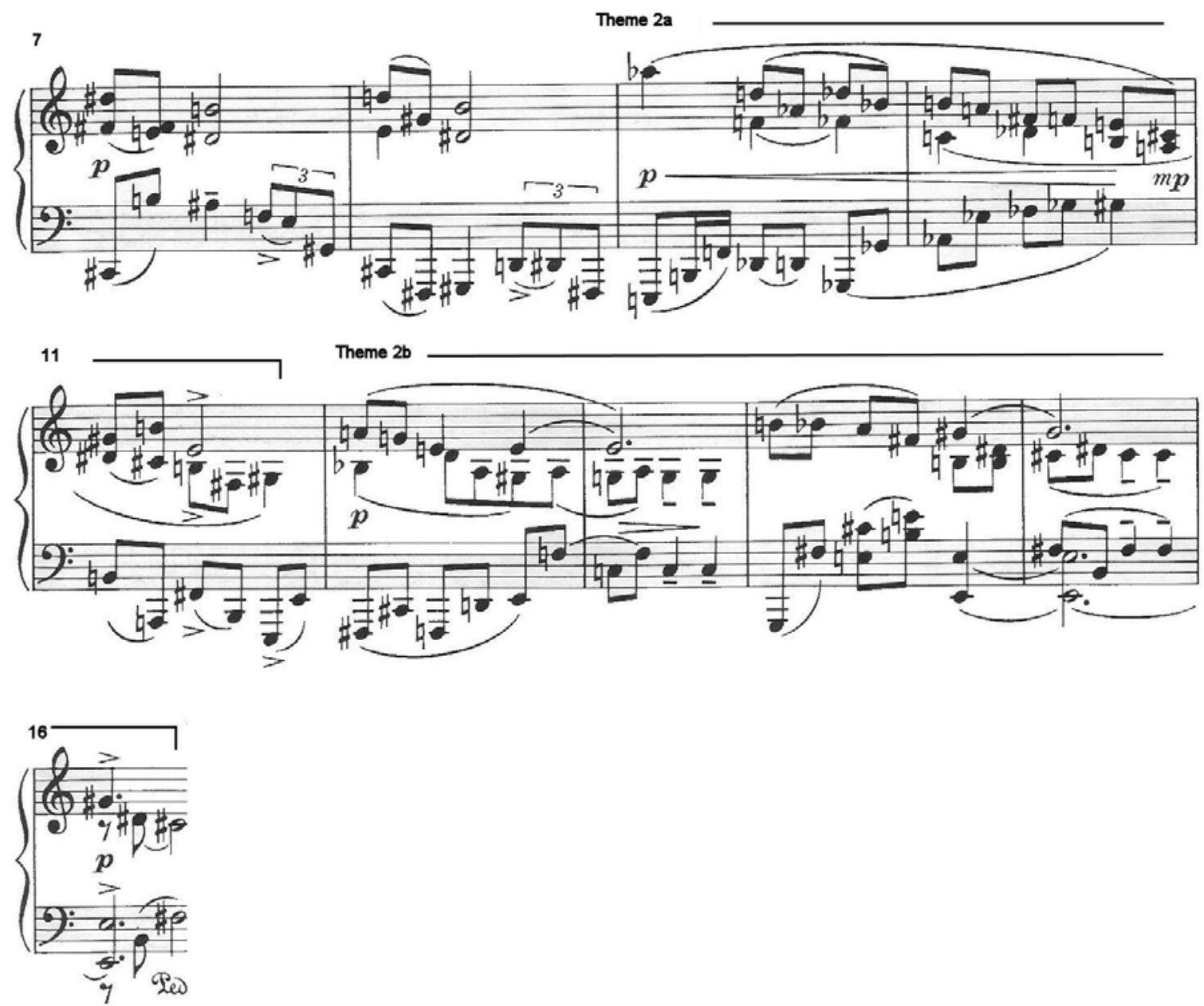

Theme 2 (Example 8) is eight measures long and is divided into two asymmetrical phrases - Theme $2 a(\mathrm{~mm} .9$-11), Theme $2 b(\mathrm{~mm} .12$ - 16). Theme $2 a$ partakes of an octatonic scale and a fragment of the blues scale before pivoting away and centering around $B$ in measure 10. The B serves as a dominant of $E$ in measure 11, resulting in the closure of Theme $2 a$ by a perfect authentic cadence ii (F\#) - V (B) - I (E) with a perfect authentic cadence. The non-functional linear chromaticism seen in Theme $2 a$ resembles 
some of Chopin's writings where a tonal goal is achieved through a series of linear progressions.

Theme $2 b$ (mm. 12 - 16) reinforces the tonal center of E. A dominant tritone substitution commonly found in the jazz harmony is outlined in the bass line of measure 12 (Example 9). Theme $2 b$ concludes with a perfect authentic cadence.

Example 9: Lullaby, tritone substitution, m. 12. Copyright (C) 1965 by C.F. Peters Corporation. All Rights Reserved. Used by permission.

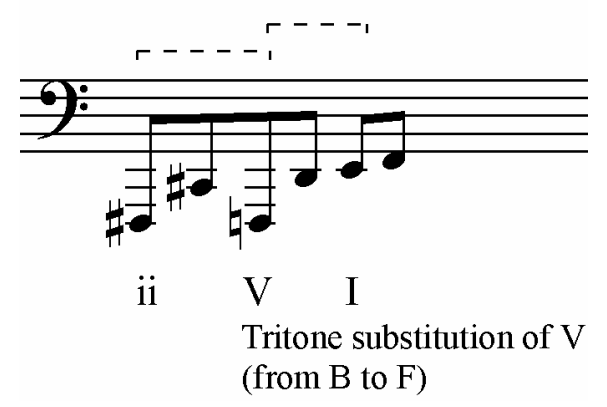

Section A’ (Mm. 17 - 32)

Themes $1 a, 1 b, 2 a$, and $2 b$ are restated with transposition of a step higher - Theme $1 a$ (mm. 17 - 20), Theme $1 b$ (mm. 21 - 24), Theme $2 a$ (mm. 25 - 27), and Theme $2 b$ (mm. 28 - 30; mm. 31 - 32 slightly modified). The transposed themes are often doubled at the octave. In addition, significant dynamic contrasts are also created between the original themes and the transposed themes. For example, Theme $1 a$ is marked piano (m. 1) versus Theme 1a transposed (m. 17) which is marked mezzo forte; Theme $2 a$ (m. 9) is marked piano as opposed to Theme $2 a$ transposed (m. 25) which is marked forte (m. 25). The texture of Themes $1 a$ and $1 b(\mathrm{~mm} .17$ - 24) prevails from the eighth-notes to primarily 
triplets rhythmic background. The range increases in the second occurrence of Themes $2 a$ and $2 b(\mathrm{~mm} .25$ - 32) compared to the original Themes $2 a$ and $2 b$ (mm. 9 - 17).

The tonal center shifts from E (mm. 11 - 16) to C beginning in measure 17, forming a mediant relationship. The presence of the $\mathrm{C}$ blues scale from measure 17 through 24 is often supported by blues notes: E-flat (lowered $3^{\text {rd }}$ ), F-sharp (enharmonic spelling of G-flat, lowered fifth) and B-flat (lowered seventh). Theme 2a concludes with a perfect authentic cadence marked by dominant (A-flat) - tonic (D-flat) in measure 27.

The second major melodic motive (motive y) also consists of a three-note figure: descending minor second followed by a descending perfect fourth. The augmented fourth formed by F-sharp and C features a tritone relationship as seen in Example 10. Motive $y$ in measure 16 leads to a $\mathrm{G}$ blues scale in measure 17. This melodic motive usually occurs as a link between phrases and sections. It first occurs in measure 16, connecting Section A and Section A'.

Example 10: Lullaby, motive y, mm. 16 - 17. Copyright ( 1965 by C.F. Peters Corporation. All Rights Reserved. Used by permission.

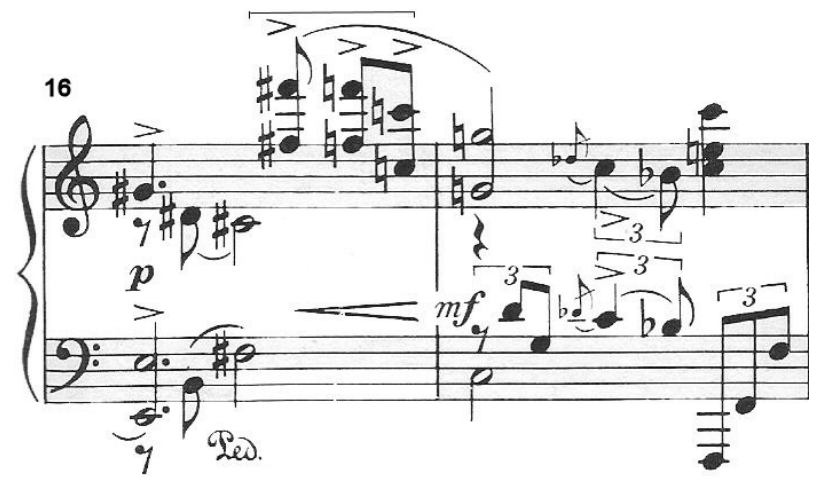


Transition 1 (Mm. 32 - 47)

Transition 1 connects Section A' and Section B. Motive $x$ that occurs in measure 32 (Example 7) begins as a pick up to Transition 1. An important melodic fragment which is derived from Theme $1 a$ can be seen in measures $40-41$. This melodic fragment is outlined in octaves in the upper staff ( $\mathrm{F}-\mathrm{B}$-flat - G - B-flat). The same melodic fragment is written a perfect fifth lower in the lower staff in measures 44 - 47 (Example 11). The fragment of Theme $1 a$ that occurs in measures 40 - 41 and measures 44 - 47 effectively echoes the theme in preparation for Section B.

Example 11: Lullaby, mm. 38 - 47. Copyright (c 1965 by C.F. Peters Corporation. All Rights Reserved. Used by permission.
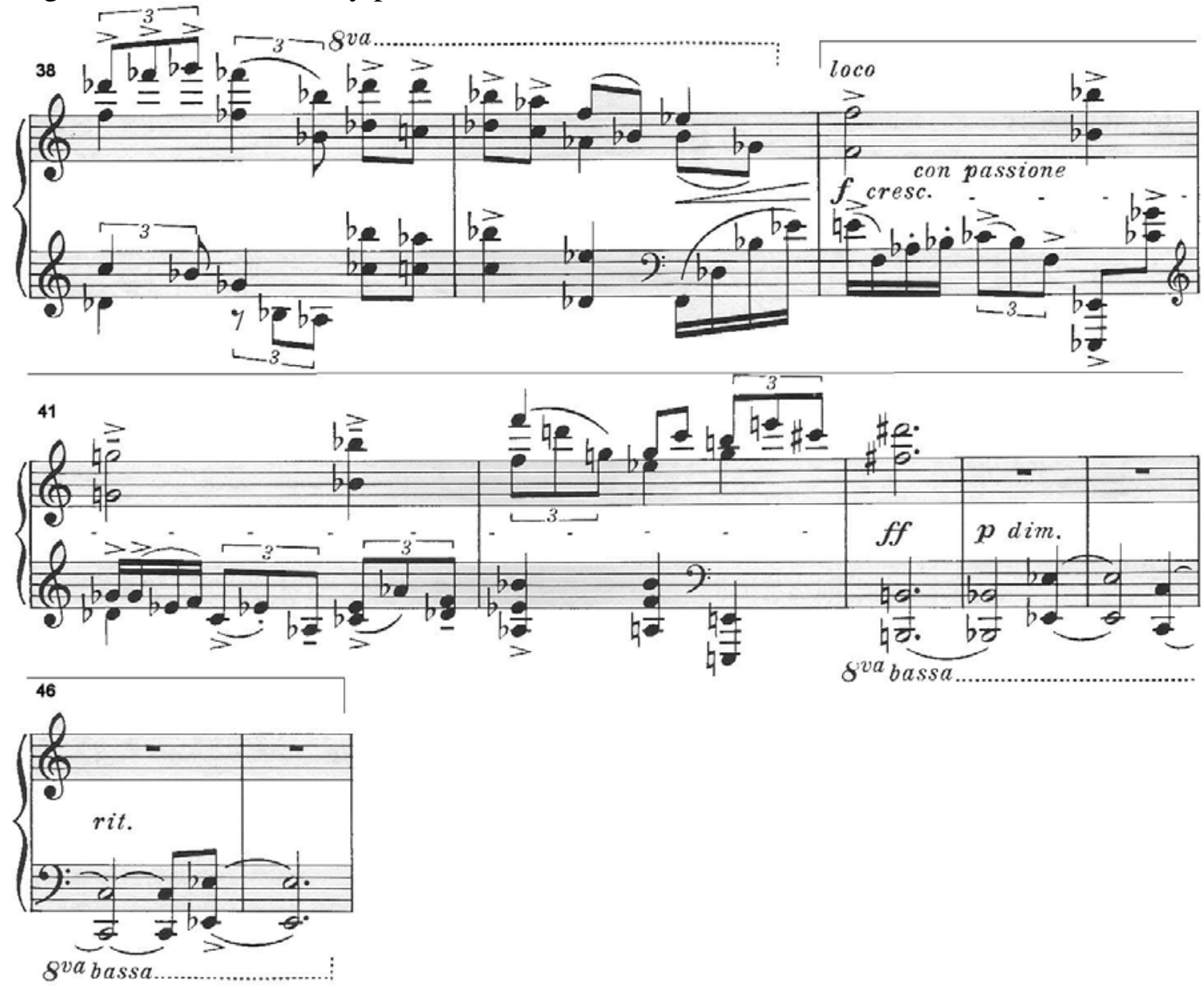
Section B (Mm. 48 - 76)

Section B, which is the most contrasting section in this moment, is embedded with motive $x$, heavily reflecting the blues spirit. Motive $x$ occurs in measures $48-49$ (variant), 52 - 53 (variant), 54, and 57 (Example 12). Other appearances of motive $x$ can also be found in measures 60, 61, 64, 67, 74, and 76. Motive y (Example 10), which serves as a link between phrases, connects measure 72 and measure 73.

Example 12: Lullaby, mm. 46 - 58. Copyright (C) 1965 by C.F. Peters Corporation. All Rights Reserved. Used by permission.
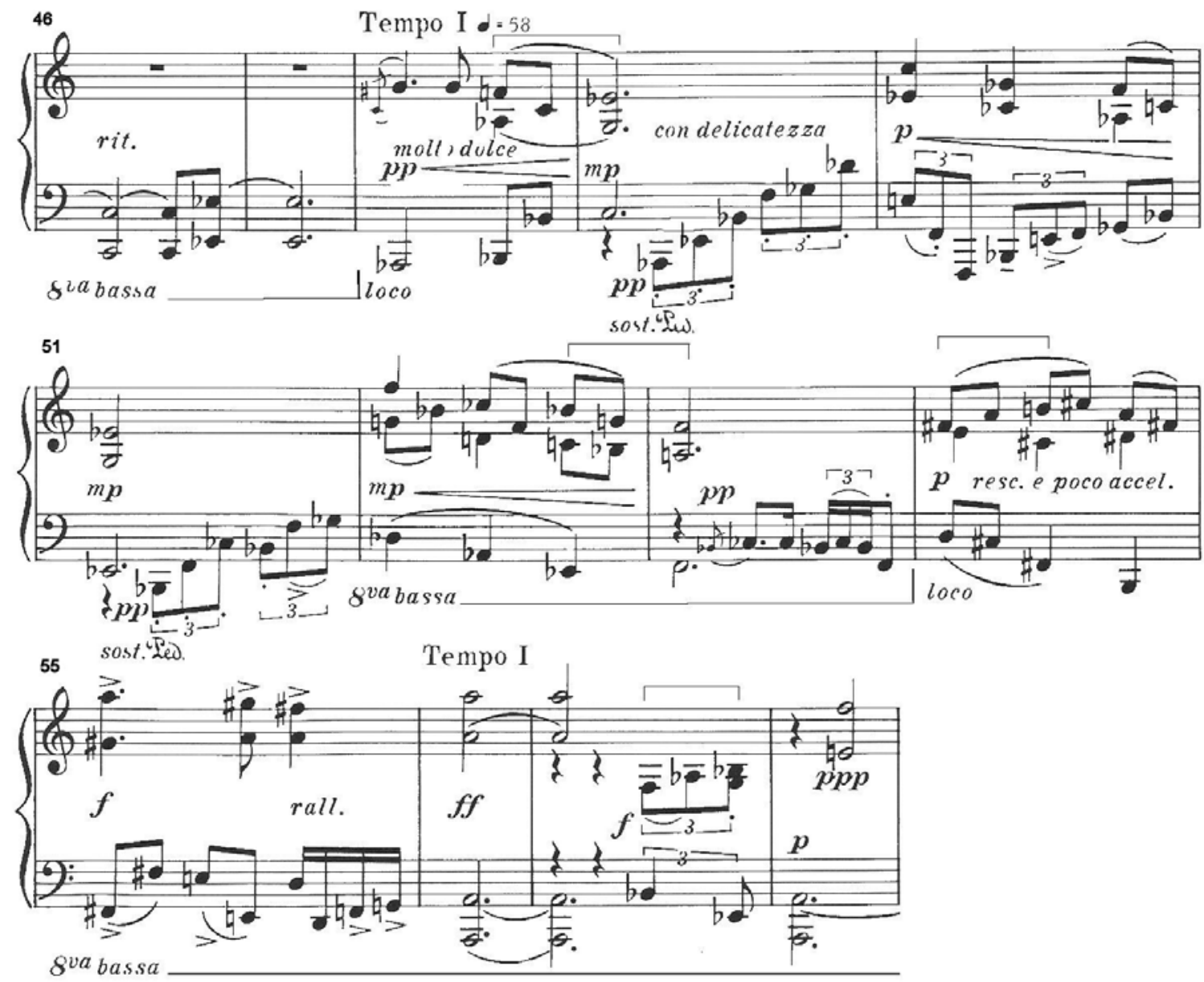
One of the main features of Section B is the extensive development of tonal centers through various blues scales, they are:

Mm. 48 - 51 - E-flat blues scale

Mm. 52 - 62 - F blues scale

Mm. 64 - 66 - B-flat blues scale

Mm. 69 - 72 - C blues scale

Section $1 / 2 \mathrm{~A}(\mathbf{m m} .77-84)$

Theme $2 a$ that occurs in measures 25 to 32 returns in exact repetition in measures

77 to 84 . In this section, Theme $1 a$ and Theme $1 b$ are both truncated (see mm. $17-24$ ).

Transition 2 (mm. 84 - 96)

Motive y (Example 10) connects Section $1 / 2 \mathrm{~A}$ in measure 84 to Transition 2 in measure 85. In Transition 2, two important blues scales are embedded in both staves. They are C blues scale (mm. 84 - 91) and E-flat blues scale (mm. 92 - 96).

\section{Section A (mm. 97 - 112) and Coda (mm. 113 - 126)}

Motive $x$ serves as a link to prepare the return of Section A. The closure of this movement is marked by the complete return of Themes $1 a, 1 b, 2 a, 2 b$, and a coda section. Themes $1 a$ through $2 b$ are written a half-step lower with exact transposition of the original. The final section, as shown in the tempo indication, Meno mosso e piu tranquillo, is to be performed in a slower tempo with much tranquility, reflecting an absolute calm resolution. 
The third significant motive (Motive $\mathrm{z}$ ) of this movement is characterized by a four-note figure (sixteenth-note triplet figure followed by an eighth note) as seen in Example 13. The rhythmic character of motive $\mathrm{z}$ is distinct but its pitch pattern is derived from motive $y$. In other words, motive $z$ is a rhythmic variant of motive $y$. This motive can be traced in the following measures 29, 34, 53, 70, 81, 93, 95, 114, and 122.

Example 13: Lullaby, m. 29 - 30. Copyright (C) 1965 by C.F. Peters Corporation. All Rights Reserved. Used by permission.

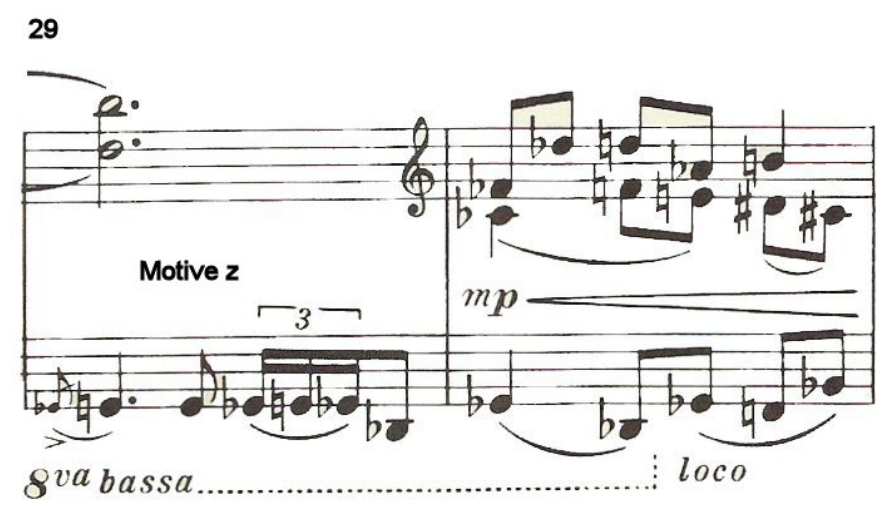


Example 14: Lullaby, mm. 112 - 126. Copyright (C) 1965 by C.F. Peters Corporation. All Rights Reserved. Used by permission.
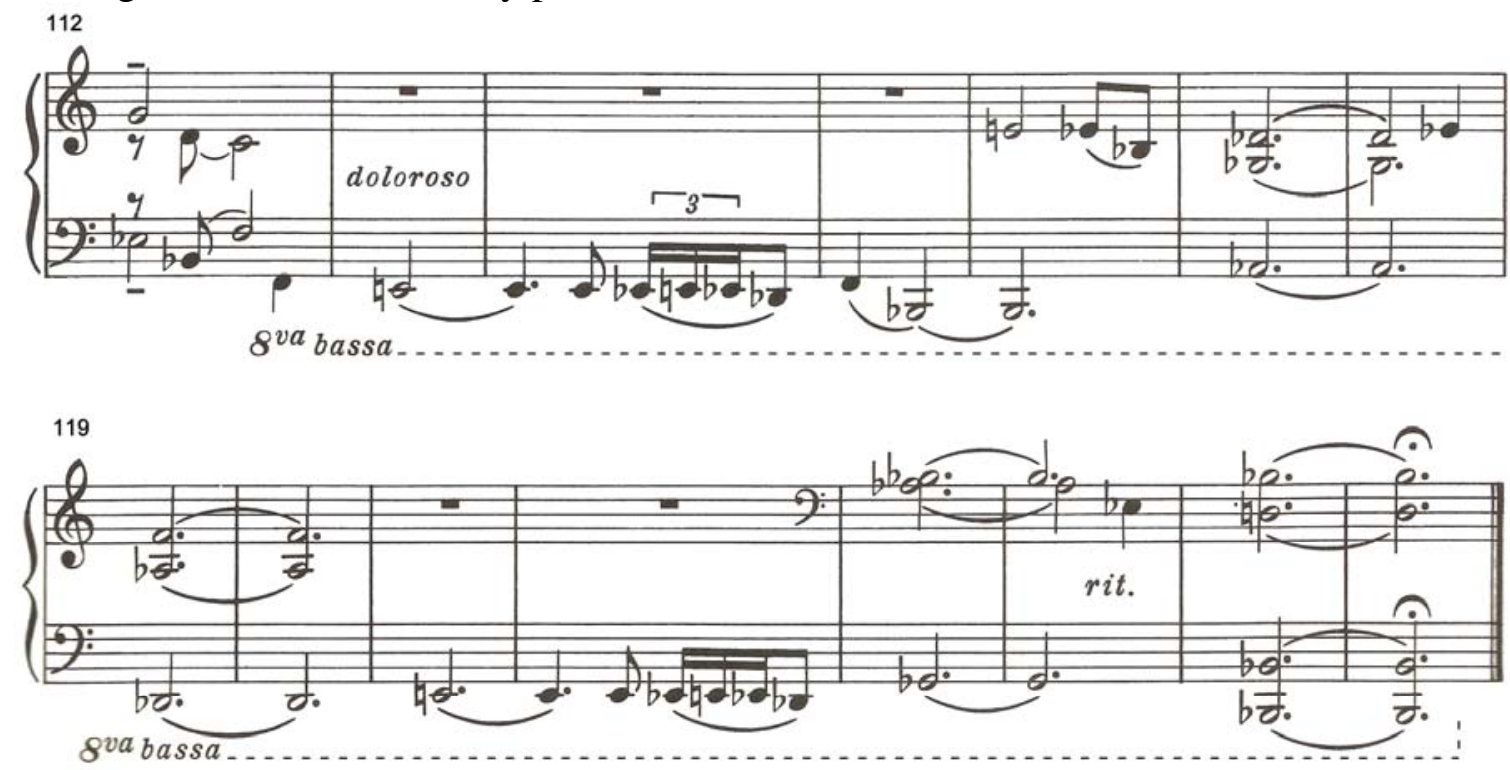

Motive $z$ occurs twice in altered form in the coda section (see Example 14). The first occurrence connects an E (m. 113) to a dominant (F) - tonic (B-flat) in measure 115. The B-flat that is held over to measure 116 forms a tritone relationship with E (m. 116) that occurs in the treble clef. The tension that is created between the tritone temporarily resolves to D-flat major (m. 119), a chord midway between B-flat and E.

The second occurrence of the sixteenth-note triplet figure in the coda links an E (m. 121) to G-flat (lowered sixth of B-flat) in measure 123. Again, a tension is built against the A-flat in measure 123 - 124, before firmly resolving to B-flat in measures 125 $-126$.

In the first movement of the sonata, G-flat (tonic) is prolonged while B-flat intervenes in the final measures. In contrast, the second movement is a closed harmonic form, beginning and ending in B-flat. 
The blues lullaby is stylistically an amalgamation of jazz dialects and classical forms. Its contrapuntal linear chromaticism is not typical of jazz; on the other hand, the blues element is not a typical style of classical compositions.

\section{Third Movement: Theme and Variations}

The third movement consists of a theme and six variations. The theme was originally written by David Amram in 1957 for a Shakespeare-in-the-Park production of Macbeth. Each variation can be divided into three sections with the third section often serving as a transition to the succeeding variations. However, one can also view some variations as written in the form of A B A' with B being a contrasting section with free motivic development and A's stating the recurring theme of the variation with modification.

Each variation has its distinct mood and character. In addition, each variation features unique harmonic and textural contrasts. The extensive use of motivic development serves to unify the theme and the variations. As a means of connecting variations, the composer sometimes uses dominant-tonic relationships to set up a succeeding variation. Other compositional devices that are employed for similar purpose include enharmonic respelling and the use of a common-tone relationship. 
Theme - Andante

The theme is written in C minor and is in compound duple (6/8) meter. It is in simple ternary form (theme $a-b-a$ ), with Themes $a$ and $b$ each falling into two fourmeasure phrases:

Theme $a-$ mm. $1-8$

Theme $b-$ mm. 9 - 16

Theme $a-$ mm. $17-24$

Theme $a$ is first stated in measures 1 - 8 with an exact repetition in measures 17 24. Theme $b$ consists of contrasting materials which also lasts eight measures. A diatonic VII - I cadence, characteristic of aeolian mode (modal jazz of the time), is found in measures 7 - 8 to mark the closure of Theme $a$. The well-balanced 3-part structure reflects a ternary form of traditional practice.

Motive $g$ shown in Example 15 is perceived as an inversion of the opening figure $(\mathrm{C}-\mathrm{G})$ in measure 1. Motive $\mathrm{g}$ (four-note figure) is characterized by a descending perfect fifth followed by a descending major second. This motive is clearly recognizable since it retains both the intervallic and rhythmic character in subsequent variations each time each returns. 
Example 15: Theme and Variations, Theme a (mm. 1 - 8), Theme b (mm. 9 - 16).

Copyright (c) 1965 by C.F. Peters Corporation. All Rights Reserved. Used by permission.
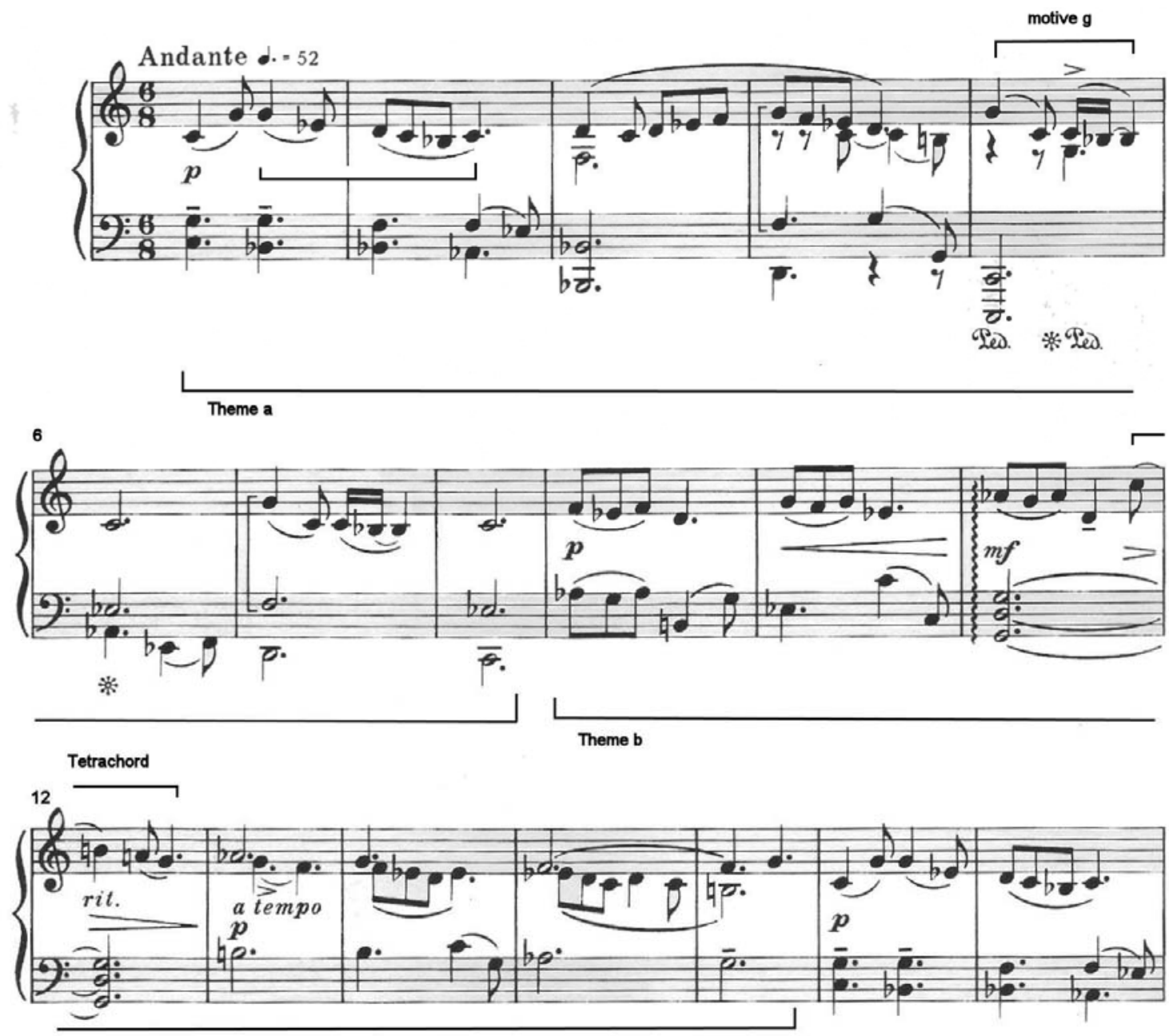

\section{Variation I - Poco meno mosso}

The first variation, like the original theme, is stated in 6/8 meter. Variation 1 constitutes a three-part form:

Section $1-$ mm. $1-5$

Section $2-$ mm. $6-12$

Section $3-$ mm. $13-16$ 
Variation I begins with an inversion of the opening figure $(\mathrm{C}-\mathrm{G})$ of Theme $a$.

This two-note descending fifth figure marks the beginning of each section. This opening figure is transposed a major sixth higher in the beginning of Section 2, and reappears in its original form $(G-C)$ in the beginning of Section 3. Example 16a shows two fragments of Theme a being stated in measures 1- 2 of Variation 1.

Example 16a: Theme and Variations, Variation 1, mm. 1 - 2. Copyright (C) 1965 by C.F. Peters Corporation. All Rights Reserved. Used by permission.

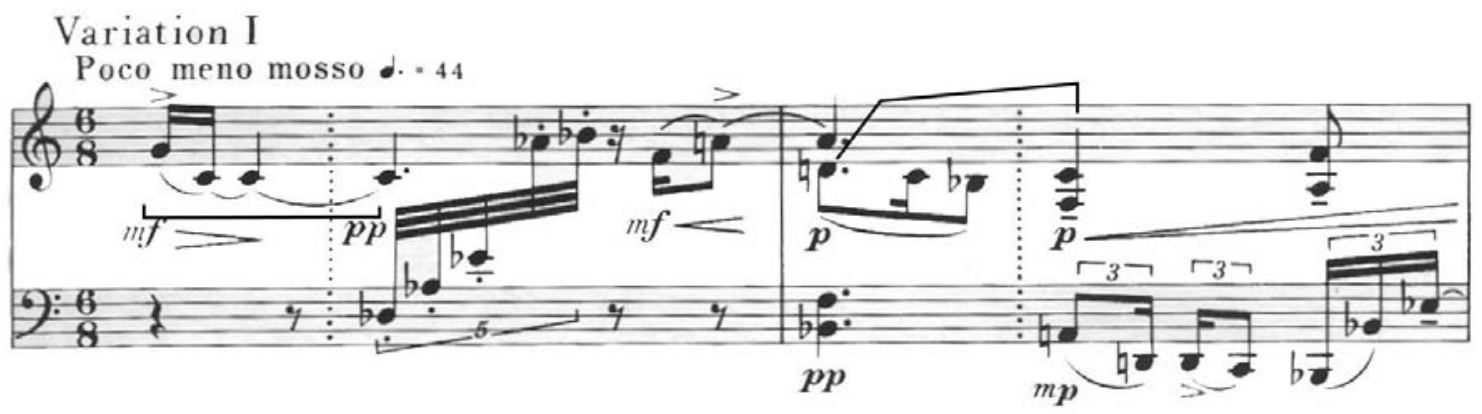

Example 16b: Theme and Variations, Variation 1, m. 2. Copyright (C) 1965 by C.F. Peters Corporation. All Rights Reserved. Used by permission.

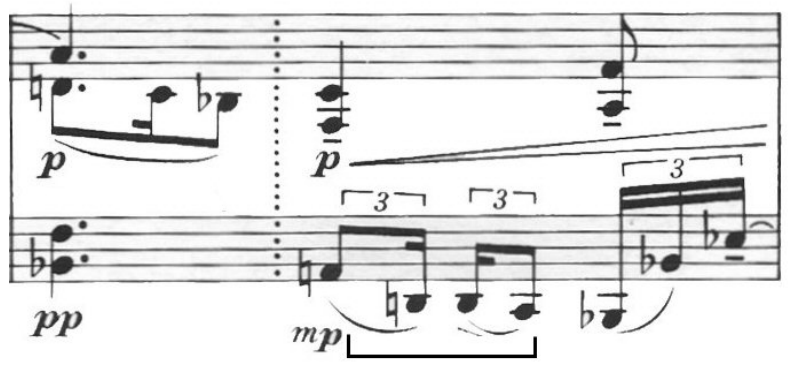

Motive $g$, which is clearly recognizable due to its distinct rhythmic characteristic, can be seen in measure 2 of this variation (Example 16b). This four-note motive appears in both diminution and transposition. It also occurs in measures 8 and 14 of Variation I. 
Quasi-improvisatory interjections are embedded in Variation 1. These

interjections are marked by light and rapid thirty-second notes in the midst of the slower passages. This stylistic gesture effectively provides rhythmic energy to the variation (Example 16c).

Example 16c: Theme and Variations, Variation 1, m. 9. Copyright (C) 1965 by C.F. Peters Corporation. All Rights Reserved. Used by permission.

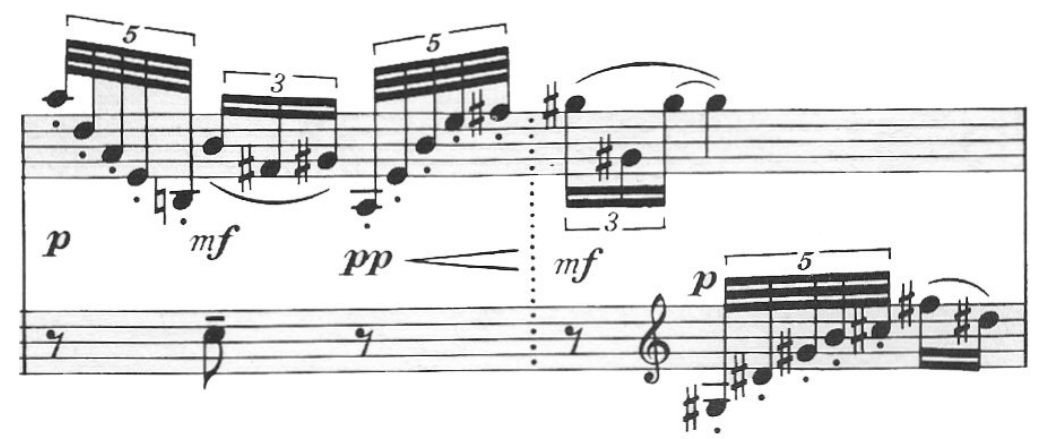

These types of rhythmic interjections which can also be seen in measures $1,3,4$, $6,10,12,13$, and 16 are not uncommon in bebop jazz.

As mentioned above, the return of the third section often serves as a transition between variations. The third section, which begins in measure 13 of Variation 1, is marked by an exact repetition of materials from measures $1-2$. In measure 15 , a fragment of Theme $b$ is quoted before the section concludes on a C-sharp (m. 16). The Csharp is enharmonically restated as D-flat (the pitch center of Variation II) to connect to the next variation (Example 16d). The indicated attaca at the end of Variation I reinforces the continuity between Variation 1 and Variation 2 (Example 16d).

Fragments of motivic ideas derived from Themes $a$ and $b$, along with motive $g$ are melodic elements that are clearly noticeable in Variation I. The development of these motivic ideas continues to serve as an important factor in uniting the theme and the subsequent variations. 
Example 16d: Theme and Variations, Variation 1, mm. 15 - 16. Copyright (C) 1965 by C.F. Peters Corporation. All Rights Reserved. Used by permission.

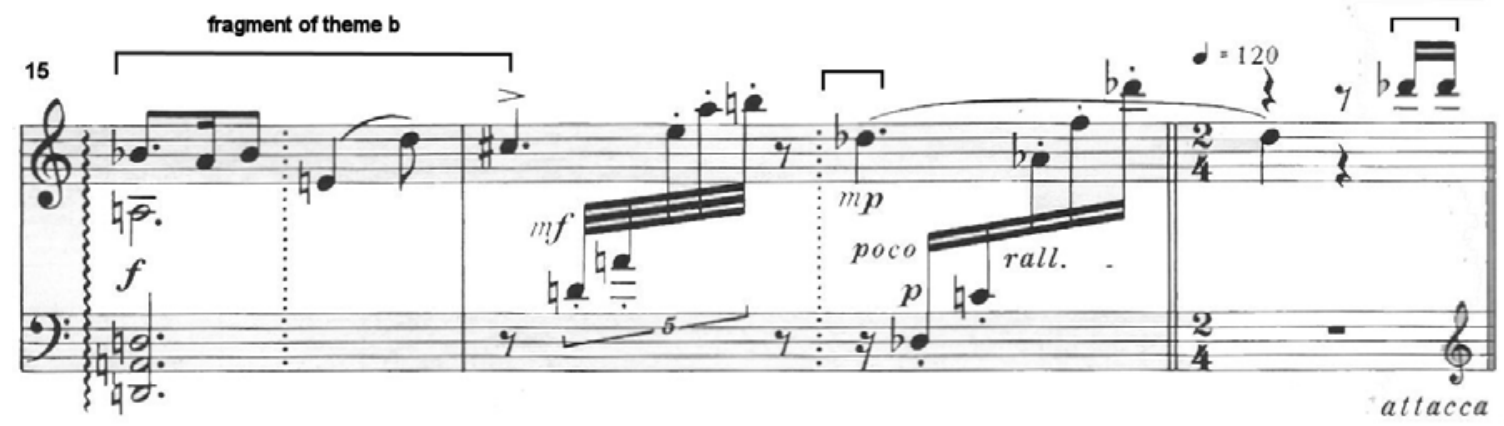

\section{Variation II - Alla marcia}

Though Alla Marcia indicates a march-like character, this variation is to be executed lightly and playfully with careful treatment of staccatos versus short slurs. The variation is technically challenging with frequent repeated notes and irregular accents in the right hand. The 2-note dyad which accompanies the melody is often placed on off beats, creating the effect of syncopation (Example 17a). 
Example 17a: Theme and Variations, Variation 2, mm. 10 - 17. Copyright (C) 1965 by C.F. Peters Corporation. All Rights Reserved. Used by permission.
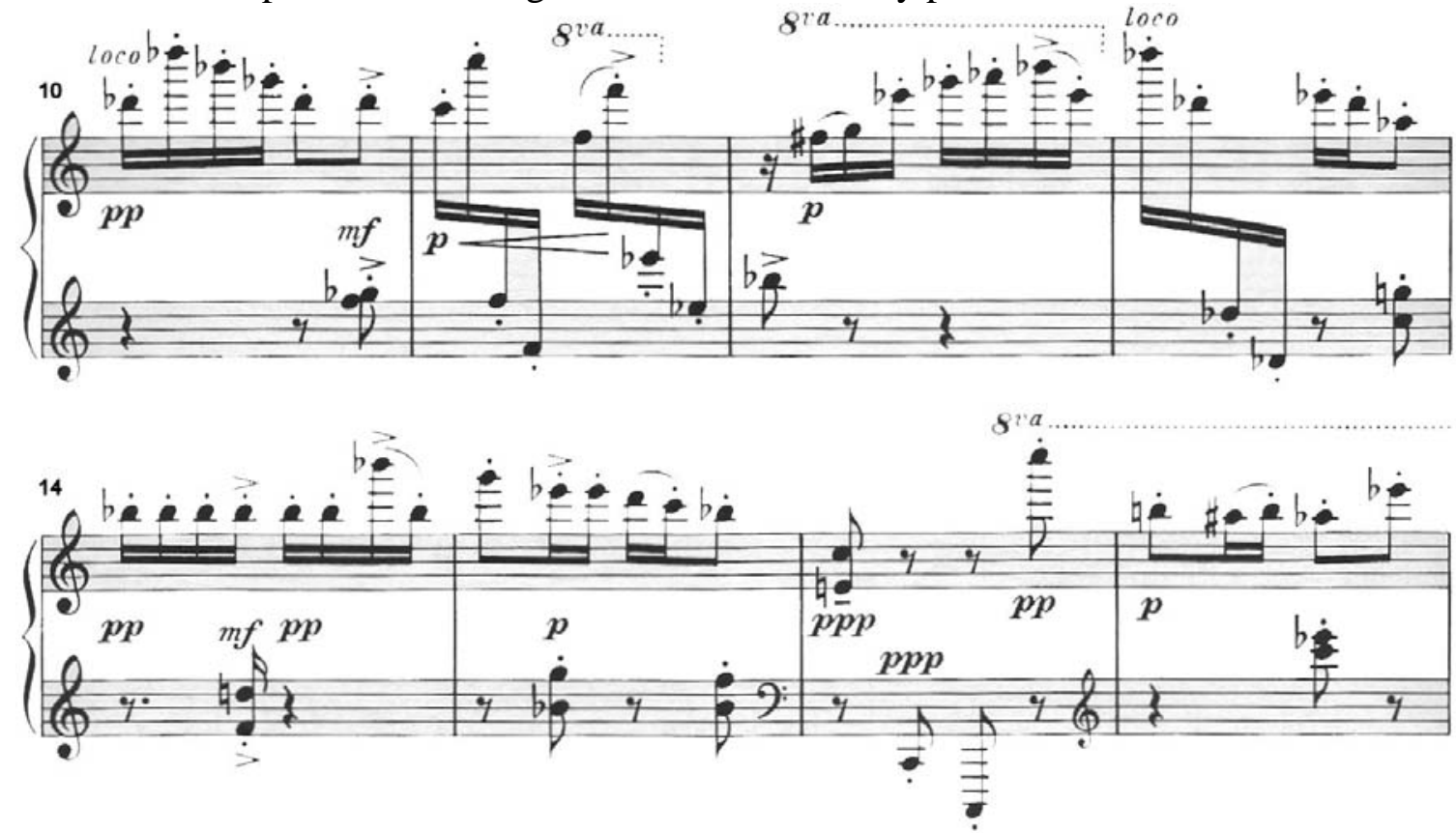

An extended-range of the keyboard is employed with the recurrent use of octave figures exhibited in this variation. These octave figures, which show a registral development of the repeated notes, often produce pointillistic effects not uncommon in some twentieth century classical compositions (see Example 17a, measures 11, 13, 14, 16, and 17). 
Example 17b: Theme and Variations, Variation 2, mm. 22 - 30. Copyright (C) 1965 by C.F. Peters Corporation. All Rights Reserved. Used by permission.
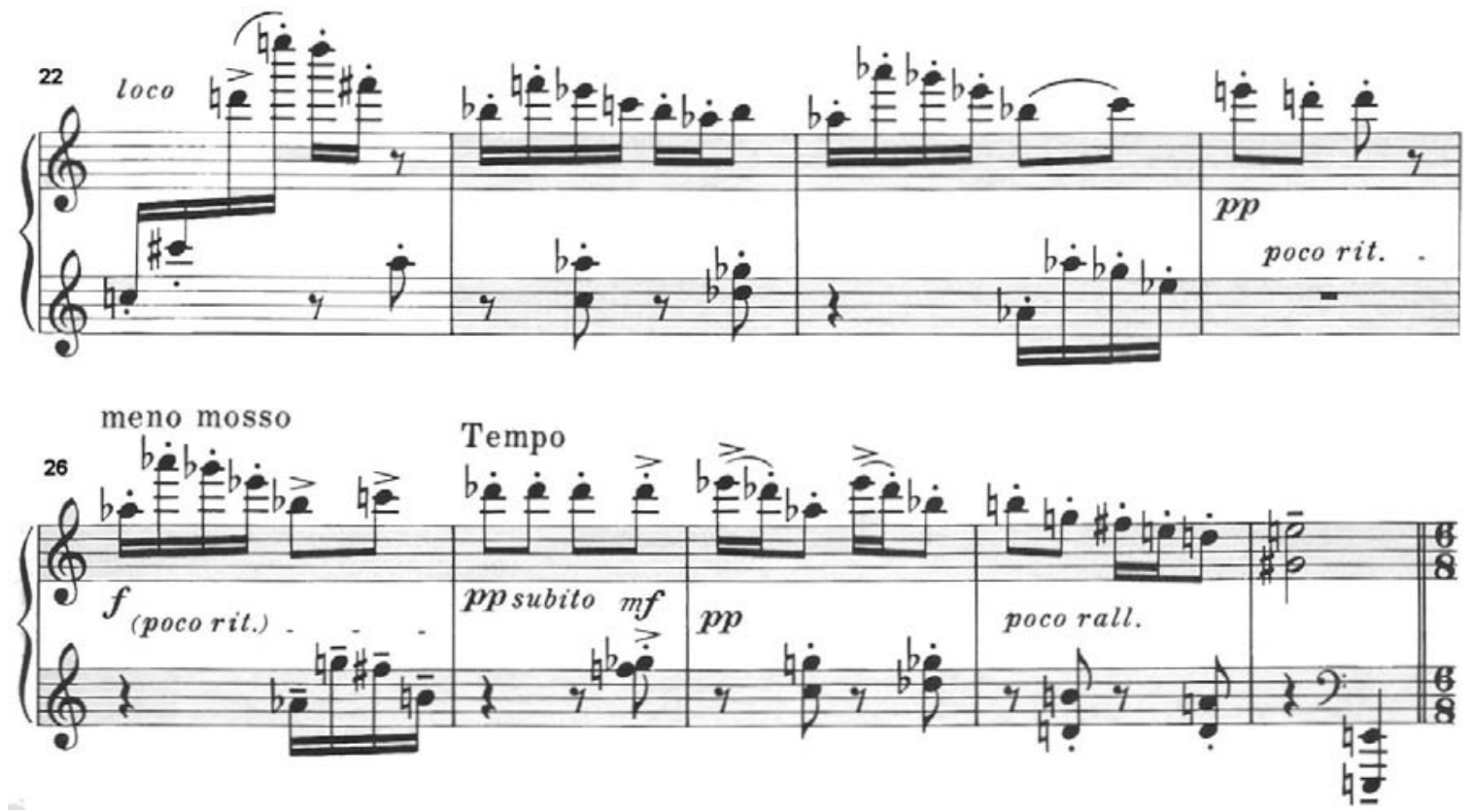

Variation II can be divided into three sections:

Section $1-$ mm. $1-16$

Section $2-$ mm. $17-26$

Section $3-$ mm. $27-30$

Identical melodic and rhythmic materials derived from measures 1 and 3 are restated in measures 27 - 28. Section 1 ends with a $C$ major chord, reflecting the same “C” tonal center as the original theme. Section 2 is characterized by unsettling tonal centers which eventually lead to the return to the initial D-flat tonal center of this variation. Section 3 which lasts four measures ends with an E major chord in the final measure. This E major chord serves as a dominant preparation for the tonal center of A in Variation III. Variation II should be performed in strict tempo except in measures 25 - 
26 (poco rit.) and measure 29 - 30 (poco rall.). The final two measures indicated with poco rall. help prepare the change of character and mood of the succeeding variation.

Variation II, like Variation I, also incorporates fragments of Theme $a$. The outline of the melodic fragment in measures $15-16$ ( $\mathrm{G}-\mathrm{E}$-flat $-\mathrm{D}-\mathrm{C}-\mathrm{B}$-flat $-\mathrm{C}$ ) reflects the rhythmically altered melody derived from measures $1-2$ of Theme a (see Example 15). A similar example in transposition is also seen in the melodic cadence in measures 29 30 (B - G - F-sharp - E - D - E).

This variation also incorporates a fragment of Theme $b$. The descending major tetrachord motive (transposed) in measures 19 - 20 outlined by pitches D - C-sharp - B A are derived from the tetrachord found in measures 11-12 of Theme $b$ (see Example 15).

\section{Variation III}

Variation III is in compound duple meter, the same as the theme and Variation I. However, the character and mood in this variation resemble a playful waltz. Variation III can also be divided into three sections:

Section $1-$ mm. $1-8$

Section $2-$ mm. $9-22$

Section $3-$ mm. $23-30$

Section 1, which centers around A, ends in measure 8 with an imperfect authentic cadence marked by V - I of A (Example 18a). Section 2 departs from a G major chord using melodic and rhythmic patterns similar to the opening phrase of Section 1 but with a constantly shifting tonal center. In Section 2, improvisatory passages (measures 13 - 22) 
and active rhythmic motions serve to develop the basic motivic idea. In many instances, blues scales are employed as a basis for improvisation. For example, the $\mathrm{C}$ blues scale can be traced in measures $19-20$ with the presence of E-flat (lowered $3^{\text {rd }}$ ), G-flat (lowered $5^{\text {th }}$ ), and B-flat (lowered $7^{\text {th }}$ ). Section 3, which is equal in length to Section 1 , again begins with melodic and rhythmic materials similar to the beginning of Sections 1 and 2.

Example 18a: Theme and Variations, Variation III, mm. 1 - 8. Copyright ( 1965 by C.F. Peters Corporation. All Rights Reserved. Used by permission.
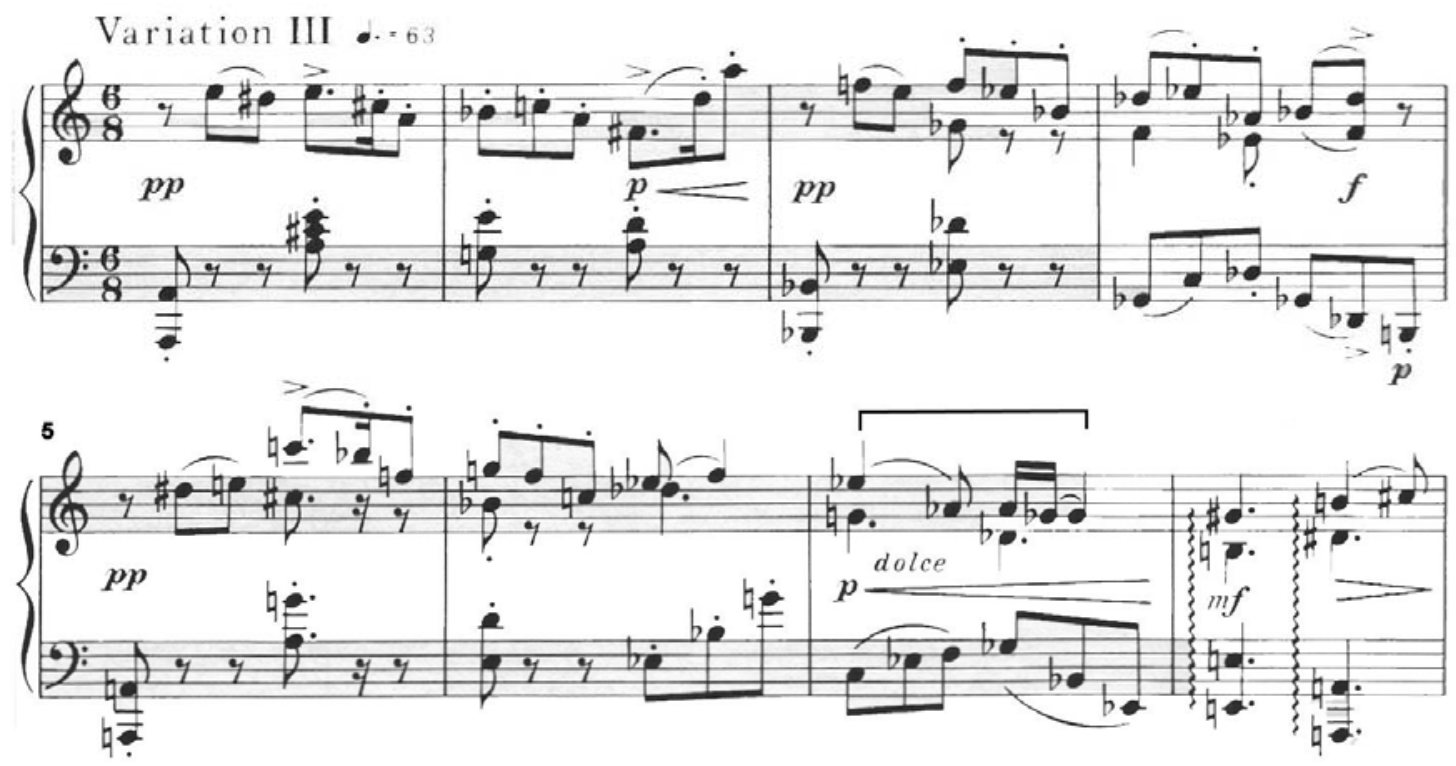

Variation III, like each of the two preceding variations, incorporates motivic development as a compositional device to unify the theme and variations. Variation III makes reference to motive $g$ in measures 7 and 27. Both occurrences have the same rhythmic features as the original motive $g$. 
Variation III is connected attaca toVariation IV through common tone 'A', which is highlighted in the final measure of Variation III via accent.

\section{Variation IV - Largo doloroso e rubato}

Variation IV is comprised of three parts. It is written in an asymmetrical meter (5/4). Each section consists of four measures:

Section $1-$ mm. $1-4$

Section $2-$ mm. $5-8$

Section $3-$ mm. $9-12$

Variation IV, which is written in A aeolian (reminiscent of the mode of the theme), calls for a sentimental nostalgia-like mood. Although this variation is written in the same mode as the original theme, it has a new theme of its own. The theme is interwoven with other voices and thus, careful balancing between the theme and other inner voices is a key ingredient in producing a good and stylistic performance. This contrapuntal balancing of voices reflects one of the characteristics of classical and, especially, romantic practices.

The harmonic progression in measures 1 through 4 outlines a descending tetrachord ( $\mathrm{A}-\mathrm{G}-\mathrm{F}-\mathrm{E})$ based on the aeolian mode. This variation is more diatonic in contrast to the preceding variations, which were more chromatic.

The guitar-like (alla chittara) embellishment that first occurs in measure 4 of this variation is derived from measure 20 of Variation II (see Example 19a). It reoccurs in measure 8 with slight rhythmic alteration. The original use of the tetrachord can be traced to the expression of Theme $b$. 
Example 19a: Theme and Variations, Variation IV, mm. 4 - 7. Copyright (C) 1965 by C.F. Peters Corporation. All Rights Reserved. Used by permission.

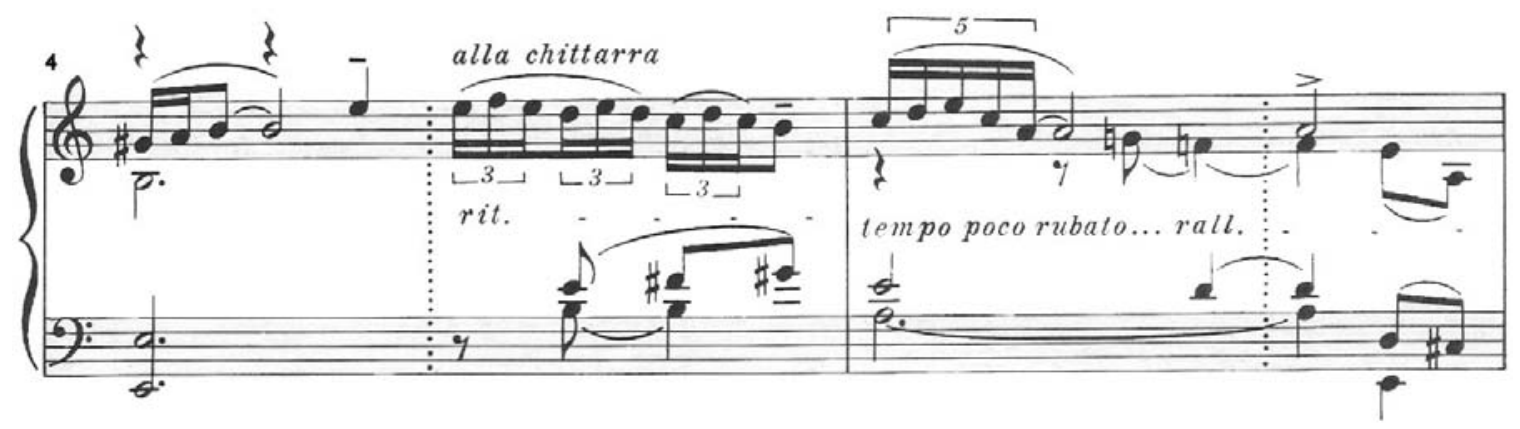

Motive $g$, is found in a clearly recognizable form on the third beat of measure 2 and the third beat of measure 7 of Variation IV.

A rapid improvisatory passage that occurs in measure 12 prepares the tempo change to Variation V (Example 19b). The driving alternating bass octaves which occur toward the end of measure 12 generate a forward momentum that propels from $\mathrm{E}-\mathrm{F}$ sharp - G-sharp to the downbeat of measure 1 of Variation V which begins on A.

Example 19b: Theme and Variations, Variation IV, m. 12. Copyright (c) 1965 by C.F. Peters Corporation. All Rights Reserved. Used by permission.

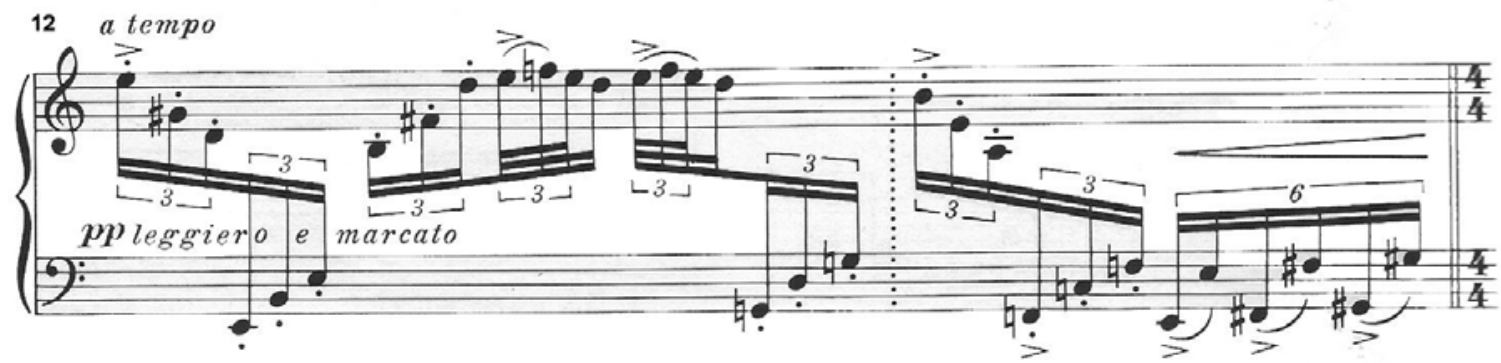




\section{Variation V}

Variation V represents one of the most jazz-like variations in this movement. It is written in simple quadruple (4/4) meter but with a constant and steady triplet subdivision. In character and in style, Variation $\mathrm{V}$ opens with a progressive 4-measure blues bass pattern in the following order (also see Example 20a):

Mm. 1 - A blues scale

Mm. 2 - G blues scale

Mm. 3 - B blues scale (The B may be seen as a tritone substitution for F)

Mm. 4 - A blues scale

The consistency of 4-measure phrases is seen throughout this variation. Although the variation is not based on a strict 12-bar blues progression, it resembles the basic form of the 12-bar blues with the addition of a 4-bar introduction. Free development of the motivic and harmonic patterns is evident in this variation. 
Example 20a: Theme and Variations, Variation III, mm. 1 - 6. Copyright (C) 1965 by C.F. Peters Corporation. All Rights Reserved. Used by permission.
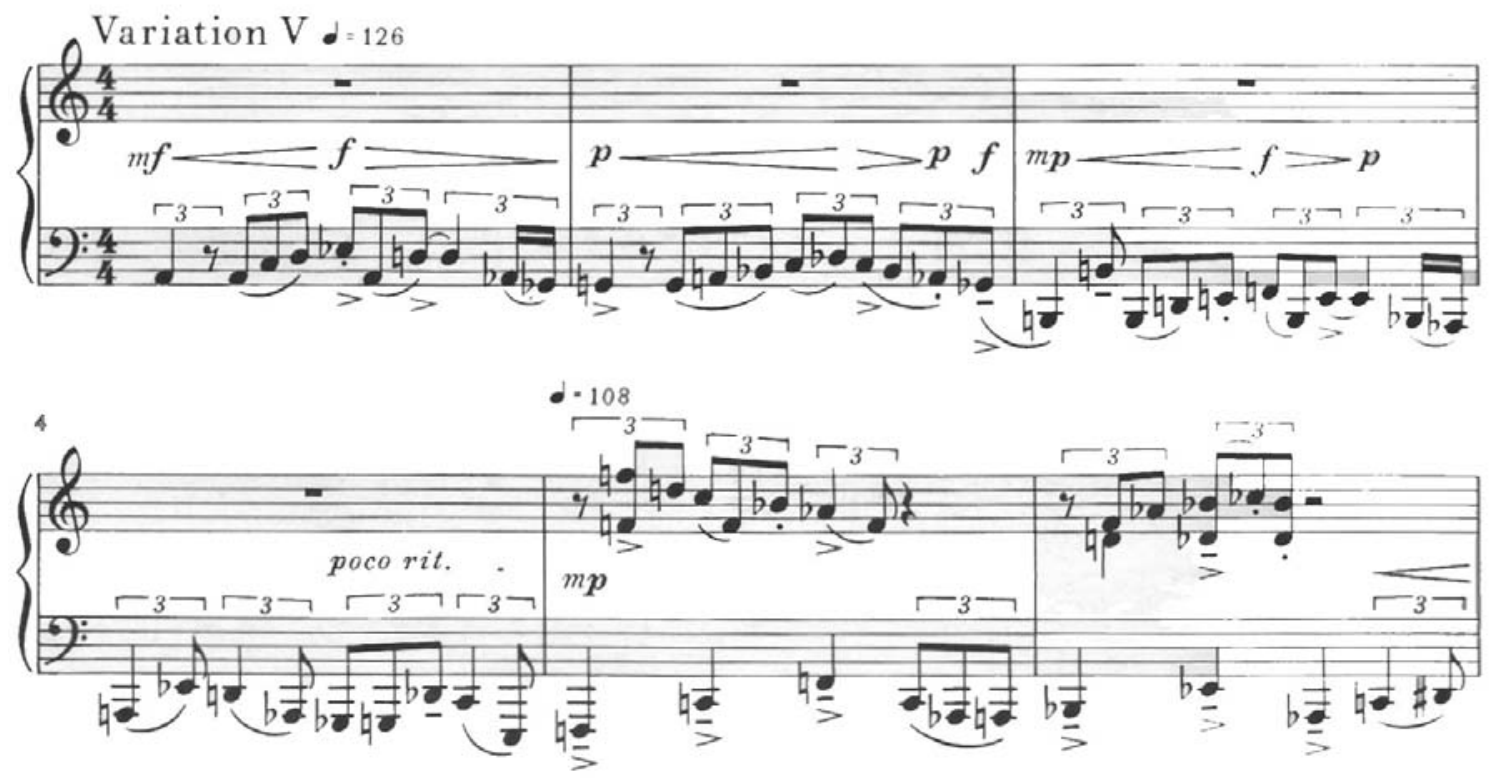

In measure 5, a slower tempo is indicated when the new theme is introduced. The incorporation of blues scales and octatonic scales is significant in this variation. Example 20b shows a fragment of octatonic and blues scales found in measure 13.

Example 20b: Theme and Variations, Variation V, m. 13. Copyright (C) 1965 by C.F. Peters Corporation. All Rights Reserved. Used by permission.

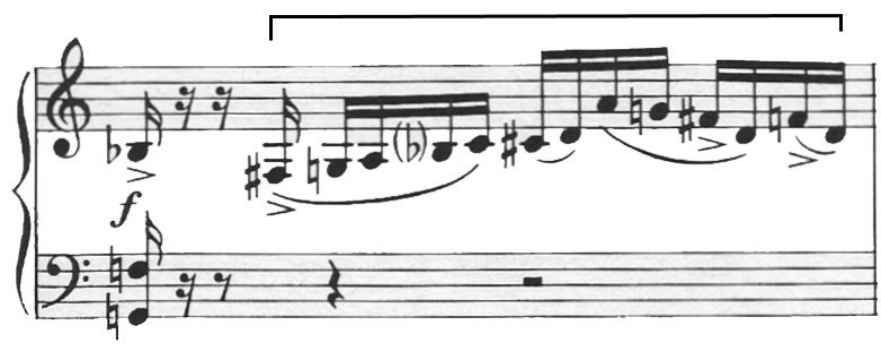




\section{Variation VI - Molto maestoso}

The climax of the third movement is reached in Variation VI. This variation comprises a series of underlying triplet melodic figurations in the right hand set against the majestic and powerful Theme $a$ in the bass in octaves. Written in 6/4 meter, the first phrase of Theme a quoted in the variation is displayed in the bass, a fourfold augmentation of the original note values of the theme (Example 21a).

Example 21a: Theme and Variations, Variation VI, mm. 1 - 2. Copyright (C 1965 by C.F. Peters Corporation. All Rights Reserved. Used by permission.

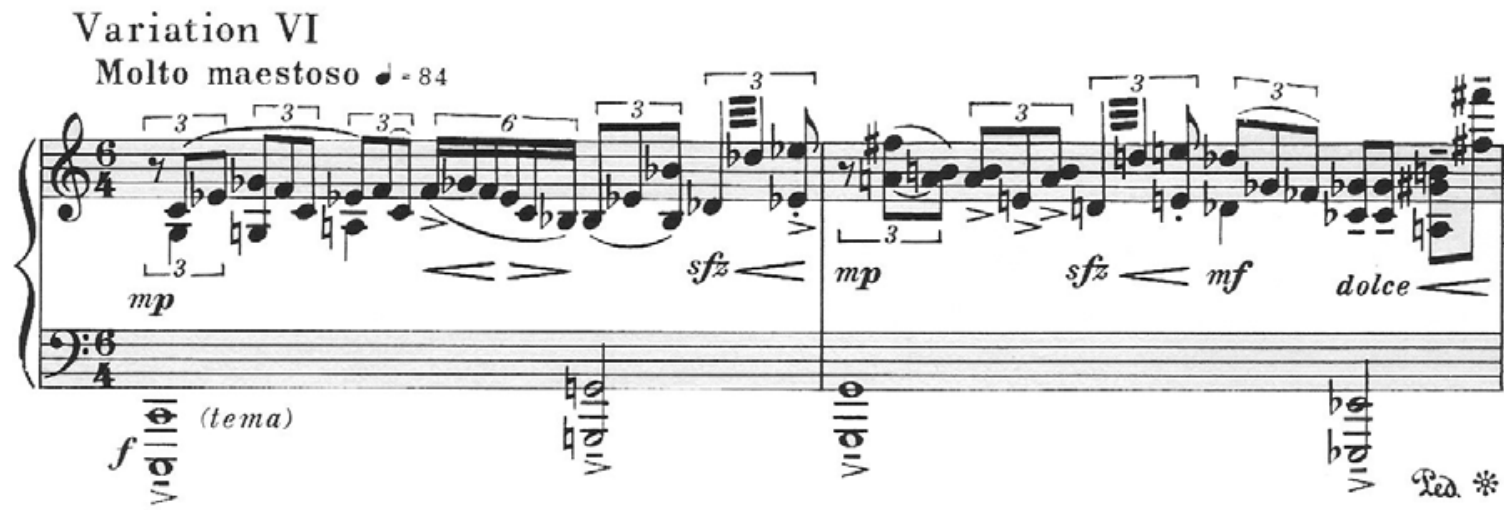

The $\mathrm{C}$ blues scale dominates the improvisatory passages that occur throughout the variation. The improvisation that occurs in measure 5 resembles the style of bebop jazz, which is characterized by rapid and intricate melodies and rhythms supported by a steady bass rhythm. Based on an octatonic scale, this passage is one of the most extensive improvisatory passages found in any of the variations (Example 21b). 
Example 21b: Theme and Variations, Variation VI, m. 5. Copyright (C 1965 by C.F. Peters Corporation. All Rights Reserved. Used by permission.

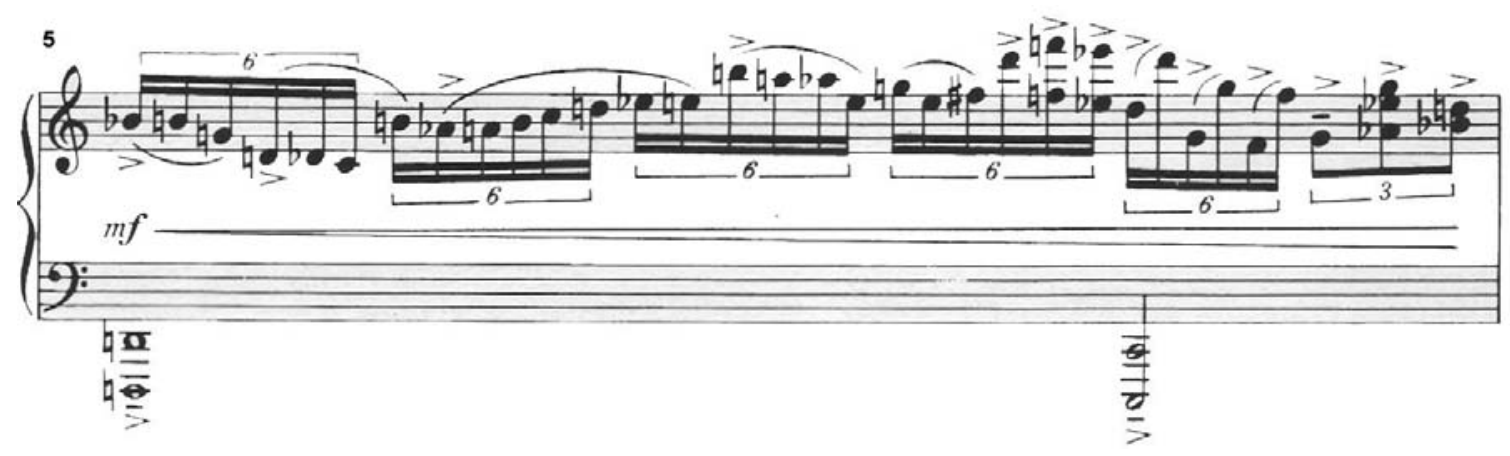

Example 21c: Theme and Variations, Variation VI, mm. 6 - 8. Copyright (C 1965 by C.F. Peters Corporation. All Rights Reserved. Used by permission.

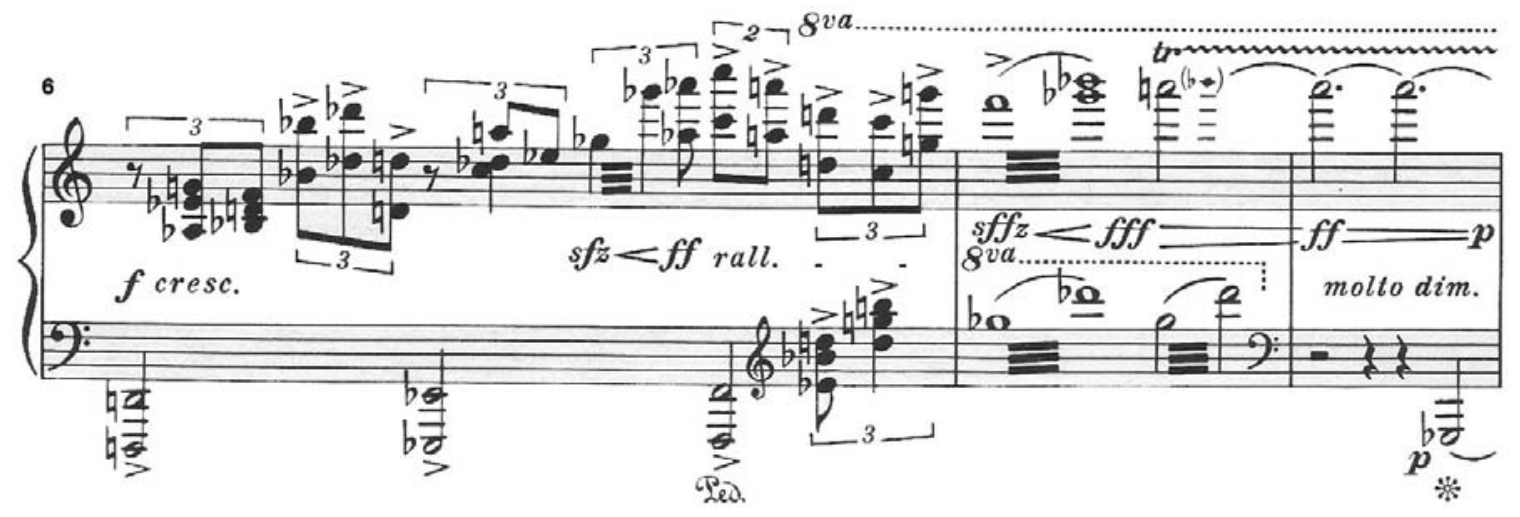

The closure of Variation VI is marked by a prolonged trill (mm. 7 - 9) in the right hand supported by G-flat (lowered $5^{\text {th }}$ of C) (Example 21c). The tension that is built on the G-flat (enharmonic of F-sharp) is resolved to $G$ in measure 11. The $G$ then functions as a dominant pedal that lasts from measure 11 to measure 16 (Example 21d). 
Example 21d: Theme and Variations, Variation VI, mm. 9 - 18. Copyright (C) 1965 by C.F. Peters Corporation. All Rights Reserved. Used by permission.
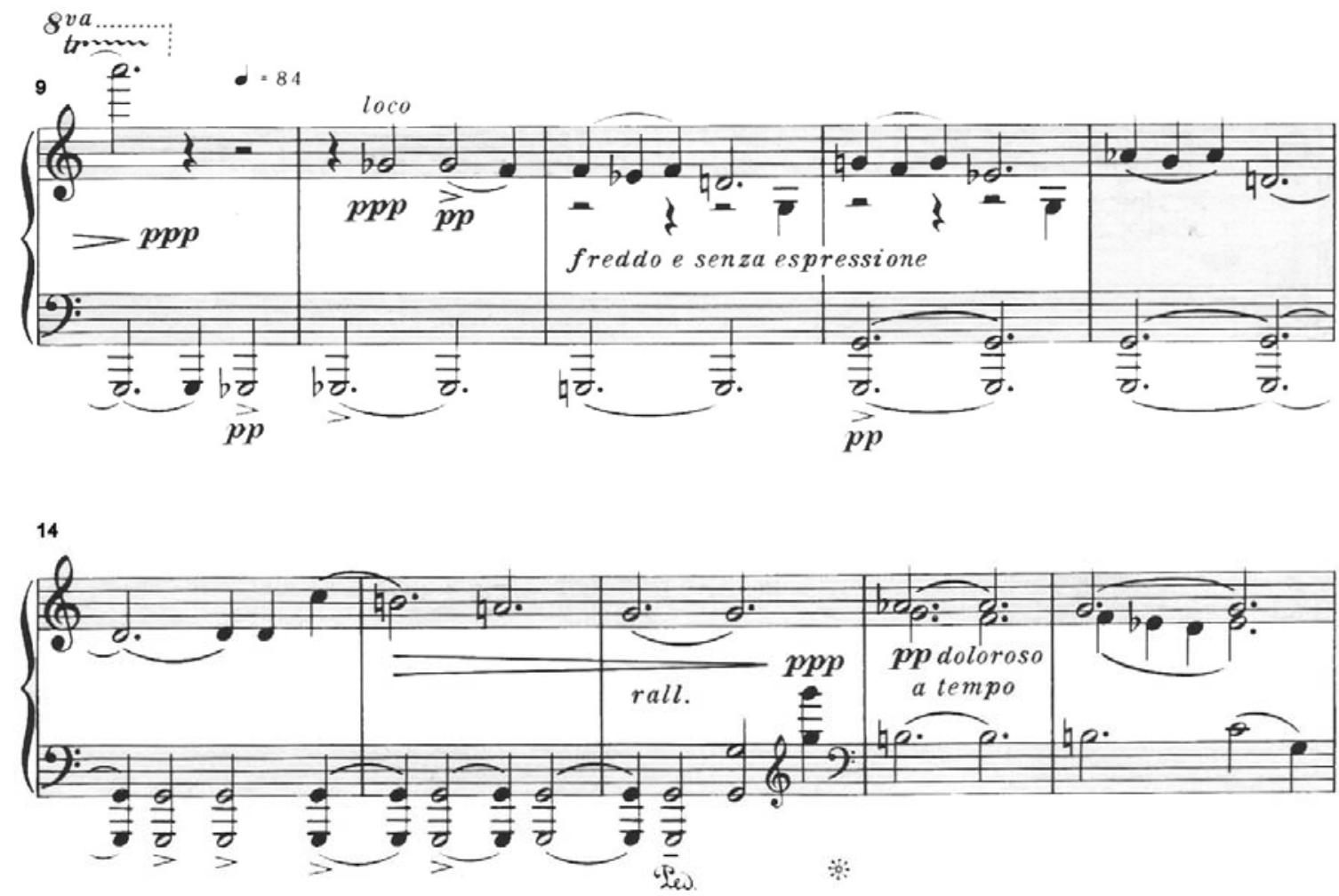

Theme $b$ (Example 15) is restated in measures 10 - 20 in augmentation over a dominant pedal, preparing the final return of the complete Theme $a$ in measures 21 - 28, which is also written in augmentation. The closure of the third movement is marked by a C major chord instead of C minor from the original themes, utilizing a Picardy third (Example 21e), giving a sense of bittersweet ending to the entire movement. 
Example 21e: Theme and Variations, Variation VI, mm. 27 - 28. Copyright (C) 1965 by C.F. Peters Corporation. All Rights Reserved. Used by permission.

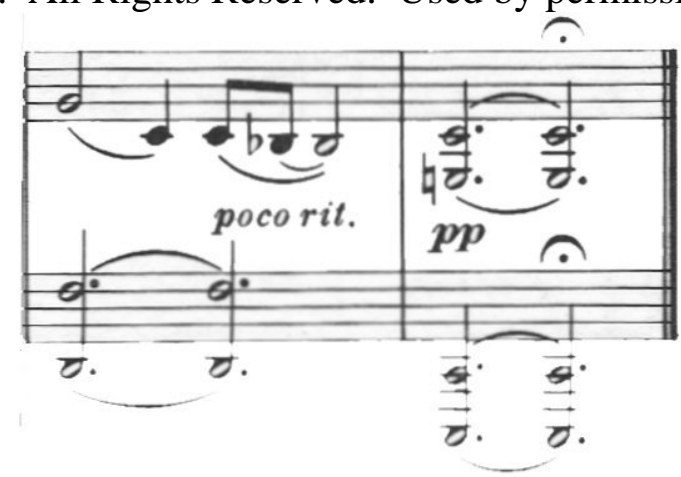

The Theme and Variations is united through free motivic developments mostly derived from Theme $a$, Theme $b$, and motive $g$ which can be consistently found in each variation. These motives often appear in disguise through inversions, rhythmic modifications, or asserted through inner voices. The Theme and Variations I - IV are all consistently presented in three-part form. Variation $\mathrm{V}$ is written in the style of a 12-bar blues while Variation IV serves like a grand finale stating the return of Theme $a$ and Theme $b$.

Each variation is embedded with some jazz-improvisatory figurations, making this set of variations one of the most jazz-like variations found in the twentieth century piano repertoire. The chromatic shifting of tonal centers displays the composer's creative expression of harmonies which often leads to unpredictable musical outcomes. The uniqueness of each variation also demonstrates the composer's versatility and capability in expressing music through various musical styles which often reflects a blend of traditional practice with the American spirit. 


\section{CHAPTER V}

\section{CONCLUSION}

Sonata for Piano is one of the most jazz-like piano sonata written in the first six decades of the twentieth century. This work represents a thorough integration of jazz dialects and classical idioms.

Each movement of the sonata is embedded with prominent jazz elements which can also be seen in selected piano works of jazz-influence composed from 1900 to 1960 surveyed in chapter two. These jazz elements include the use of syncopated rhythms, quasi-improvisatory passages, and melodies/harmonies which are based on blues scales.

The Overture possesses the basic structure of the classical sonata-allegro form. The main themes (Themes $1 a$ and $1 b$ ) are driven by the syncopated rhythms, often times with accented chordal anticipations. The main themes are contrasted with the expressive nostalgia-like secondary theme (Theme 2) in texture and character. The Lullaby, which is heavily filled with the blues spirit, evokes the singing of the blues. It is written in the blues idiom with the contrapuntal voices derived from the classical practice. The uniqueness of the theme and each variation in the third movement portrays the composer's versatility and capability in expressing music through various musical styles. It represents a thorough synthesis of the traditional western harmonic language and form with the spirit and dialect of jazz.

The Sonata for Piano is not a composition written to imitate the style of jazz. It is a work written by a composer who is deeply rooted in both classical and jazz. The 
composition is an expression of the thorough integration of two musical traditions classical and jazz, by a man who is fully engaged with both. As Amram himself has stated, for a composer, drawing upon these musical experiences is something that occurs naturally.

It is an important solo piano piece that should be included as part of today's piano literature. Sonata for Piano is highly recommended for pianists who are interested in exploring the richness of jazz traditions in a classical performance setting. 


\section{SELECTED BIBLIOGRAPHY}

\section{Books}

Alldis, Dominic. A Classical Approach to Jazz Piano: Exploring Harmony. Milwaukee, WI : Hal Leonard Corp., 2000.

. A Classical Approach to Jazz Piano Improvisation. Milwaukee, WI: Hal Leonard Corp., 2003.

Amram, David. Offbeat: Collaborating With Kerouac. New York: Thunder's Mouth Press, 2002.

. Vibrations: The Adventures and Musical Times of David Amram. New York: Thunder's Mouth Press, 2001.

Axford, Elizabeth C. Traditional World Music Influence in Contemporary Solo Piano Literature: A Selected Bibliographic Survey and Review. Lanham, Maryland: Scarecrow W. Press, Inc., 1997.

Berger, Arthur. Aaron Copland. New York: Oxford University Press, 1953.

Budds, Michael. Jazz in the Sixties: The Expansion of Musical Resources and Techniques. Iowa City: University of Iowa Press, 1978.

Doerschuk, Robert. The 88 Giants of Jazz Piano. San Francisco: Backbeat Books, 2001.

Friskin, James, and Irwin Freundlich. Music for the Piano: A Handbook of Concert and Teaching Material from 1580 to 1952. New York: Dover Publications, 1973.

Gershwin, George, and Ira Gershwin. Gershwin Years in Song. New York:

Quadrangle/The New York Times Book Company, 1973.

Goldberg, Isaac. George Gershwin: A Study in American Music. New York: Simon and Schuster, 1931.

Gordon, Stewart. A History of Keyboard Literature: Music for the Piano and Its Forerunners. New York: Schirmer Books, 1996.

Gridley, Mark. Jazz Styles: History \& Analysis. $6^{\text {th }}$ ed. New Jersey: Prentice Hall, 1978.

Kirby, F. E. Music for Piano: A Short History. New Jersey: Amadeus Press, 1995.

Kostka, Stefan M. Materials and Techniques of Twentieth-Century Music. Upper Saddle River, N.J.: Prentice Hall, 1999. 
Lawn, Richard, and Jeffrey L. Hellmer. Jazz: Theory and Practice. Los Angeles: Alfred Publishing Co., 1996.

Levine, Mark. The Jazz Theory Book. Petaluma, CA: Sher Music, 1995.

Persichetti, Vincent. Twentieth-Century Harmony, Creative Aspects and Practice. New York: W. W. Norton, 1961.

Pollack, Howard. Aaron Copland: The Life and Work of an Uncommon Man. New York: Henry Holt and Company, 1999.

Schiff, David. The Music of Elliot Carter. Ithaca, New York: Cornell University Press, 1998.

Williams, Martin. The Jazz Tradition. $2^{\text {nd }}$ ed. New York: Oxford University Press, 1993.

\section{Articles}

Amram, David. “The Five Keys to the Composer’s Kingdom.” Music Journal 21:4 (April 1963): 26.

Franckling, Ken. “David Amram’s Global Music.” Jazz Times - America’s Jazz Magazine 21:4 (June 1991): 28.

Fruchter, R. “A Musician for Whom There Are No Bounds.” New York Times (September 11, 1994).

Henry, Derrick. “Chamber Players Are Adept at 'Conversations'.” The Atlanta Journal and Constitution (January 21, 1989).

. "Musician Amram Shares His Passion for Music in 'Conversations'.” The Atlanta Journal and Constitution (January 19, 1989).

Kleppinger, Stanley V. "On the Influence of Jazz Rhythm in the Music of Aaron Copland,” American Music Vol. 21, no. 1 (Spring 2003): 74 - 111.

Osborne, Robert. “Three Shakespeare Songs,” Notes. 45 (September 1988): 164-5.

Porter, Lewis. “Havana/New York.” Black Perspective in Music 7:1 (Spring 1979): 113.

Silsbee, K. “David Amram Interview.” Cadence xxiv/6 (1998): 22.

Tupta, Patricia, and Marienne Uszler. “Jazz...From a Distance.” The Piano Quarterly 141 (Spring 1988): $10-16$. 
Wheaton, Jack. “Jazz Piano Styles.” The Piano Quarterly 141 (Spring 1988): 18 - 25.

Wyatt, Robert. "The Seven Jazz Preludes of George Gershwin: A Historical Narrative.” American Music Vol. 7, no. 1 (Spring 1989): 68 - 85.

\section{Dictionaries/Indices}

Ewen, David. “Amram, David Werner,” American Composers: a Biographical

Dictionary. New York: G.P. Putnam’s Sons, 1982.

Hinson, Maurice. Guide to the Pianist's Repertoire. Second, Revised, and Enlarged Edition. Bloomington \& Indianapolis: Indiana University Press, 1987.

Kirchner, Bill, ed. The Oxford Companion to Jazz. New York: Oxford University Press, 2000.

Lebrecht, Norman. "David (Werner) Amram," The Companion to 20th Century Music. New York: Oxford University Press, 1994.

Moritz, Charles, ed. “Amram, David (Werner),” Current Biography Yearbook. New York: The H. W. Wilson Company, 1969.

Randel, Don Michael, ed. The Harvard Dictionary of Music, $4^{\text {th }}$ ed. Cambridge, MA: The Belknap Press of Harvard University Press, 2003.

The Music Index: A Subject-Author Guide to Music Periodical Literature. Warren: Harmonic Park Press, 1950 - 2000.

\section{Dissertation and Theses}

Aybar, Isidro Jr. "The Confluence of Latin-Caribbean Musical Styles and TwentiethCentury Symphonic Techniques: An Original Composition with Supporting Analysis, and an Analysis of En Memoria De Chano Pozo By David Amram.” D.A. diss., University of Northern Colorado, 2002.

Bang, Keum Ju. "The Study of Representative Twentieth-Century Piano Compositions Appropriate for Use in Contemporary College Piano Literature Classes.” Ed.D. diss., Columbia University Teachers College, 1997.

Bieritz, Gerald L. "The Songs of David Amram: A Representative Analysis and Review of Published Vocal Music for Accompanied and Unaccompanied Solo Voice.” D.M.A. diss., University of North Texas, 2001. 
Bird, Robert Atkinson. "Methods and Categories of Jazz Analysis: A Critical Review of Five Approaches to Jazz History and Musical Analysis.” M.A. thesis., University of Wisconsin, 1976.

Boulton, Kenneth Owen. “The Solo Piano Music of Elie Siegmeister.” D.M.A. diss., University of Maryland at College Park, 1997.

Case, Nelly Maude. "Stylistic Coherency in the Piano Works of Aaron Copland.” PhD. diss., Boston University, 1972.

Gillespie, Luke. “Jazz Influence in Copland’s Piano Concerto (1926): Social Context and Musical Characteristics.” Doctoral Essay, Indiana University School of Music, 1997.

Haberkorn, Michael. "A Study and Performance of the Piano Sonatas of Samuel Barber, Elliot Carter, and Aaron Copland.” Ed.D. diss., Teachers College, Columbia University, 1979.

Helgeland, Kirsten Joan. "Jazz and the Classics: A Study of American Crossover Solo Piano Works from 1920 to 1935.” PhD. diss., University of Cincinnati, 1999.

Hillborn, William Dean. "A Discriminative Study on the Influence of Jazz on Serious Composers.” M.A. thesis, University of Missouri, 1962.

LoBalbo, Anthony C. “A Performance Guide to Selected Piano Music of George Gershwin.” PhD. diss., New York University, 1982.

Lynch, John P. "Emblems: Signifiers of Stylistic Coherence in the Formulation of an American Sound in This and Other Selected Works of Aaron Copland.” D.M.A. thesis, University of Cincinnati, 1996.

Perkyns, Jane E. Gormley. “An Analytical Study of Elliott Carter’s Piano Sonata.” D.M.A. diss., The University of British Columbia, 1990.

Santander, Andrew Michael. “David Baker’s Sonata I for Piano: Background, Compositional Style, and Performance Considerations.” D.M.A. diss., University of Georgia, 1988.

Sifferman, James Philip. “Samuel Barber’s Works for Solo Piano.” D.M.A. diss., University of Texas at Austin, 1982.

Tanner, Warren. “Technical Analysis of the Development of Jazz.” M.A. diss., University of California at Los Angeles, 1962.

Walker, Rosilee. “The Piano Novelty: A Distinct Musical Genre.” D.M.A. diss., University of Missouri-Kansas City, 1994. 
Yampolsky, Carol Jane. “The Solo Jazz Piano Music of Three American Composers: Armando "Chick" Corea, William "Billy” Taylor, Mary Lou Williams: A Performance-Tape Project.” D.M.A. diss., University of Maryland, 1986.

\section{Interview/Communications}

Amram, David. Telephone interview by author, 5 April 2005. . Email communication with author, 25 September 2005.

. Email communication with author, 6 November 2005. . Email communication with author, 28 April 2006.

\section{Music Scores}

Alldis, Dominic. A Classical Approach to Jazz Piano. London: Dominic Alldis, 1995.

Ambersold, Jamie, and Ken Slone. Charlie Parker Omnibook. Published by Michael H. Goldsen. Atlantic Music Corp. 1978.

Amram, David. Sonata for Piano. New York: C. F. Peters Corporation, 1965. . Conversations. New York: C. F. Peters Corporation, 1992.

Barber, Samuel. The Samuel Barber: Complete Piano Music. American Composers Series. New York/London: G. Schirmer, 1984.

Copland, Aaron. Four Piano Blues. New York: Boosey \& Hawkes, 1949.

Elie Seigmeister. Composer's note preceding his American Sonata. New York: Carl Fischer, 1945.

Ferrara, John. Jazz Piano and Harmony: A Fundamental Guide. [S.l]: John Ferrara Music, 2000.

Gershwin, George. George Gershwin's Preludes for Piano. New York: New World Music Corporation, 1927.

Rochberg, George. Carnival Music: Suite for Piano Solo. Bryn Mawr, PA: Theodore Presser Company, 1975. 


\section{Music Transcriptions}

Monk, Thelonius. Thelonious Monk's Piano Originals: Revealing Instincts of the Genius of Jazz. New York: Jazz Standard Music, 1958.

. Thelonious Monk Plays Standard, Volume 1 and Volume 2.

Milwaukee, W.I.: Hal. Leonard Corporation, 2002.

Parker, Charlie. Charlie Parker Omnibook. Transcribed by Aebersold, Jamey, and Ken Slone. Published by Michael H. Goldsen. New York: Atlantic Music Corp., 1978.

\section{Online Resources}

Amram, David. "Classical Compositions by David Amram.” http://www.davidamram.com/classical_compositions.html; assessed April 11 2005.

. "The Biography of David Amram.”

http://www.fmp.com/amram/AmramBiography.html; assessed 2 February 2005.

. "The Homepage of David Amram at Home Around the

World...composer /conductor/multi-instrumentalist, a living American treasure.” http://www.davidamram.com; assessed 2 February 2005.

Blumenthal, Bob. “Amram takes the world with him when he tours.” The Boston Globe, 3 February, 1999. Internet. Available from

http://www.fmp.com/amram/inthenews.html; assessed 2 February 2005.

Brown, Steven. “Composer David Amram pays homage to Jack Kerouac.” Orlando Sentinel, 16-22 April, 1999. Internet. Available from

http://www.fmp.com/amram.inthenews.html; assessed 3 February 2005.

Gillespie, Don C., and Barbara A. Petersen. “Amram, David.” Grove Music Online. http://www.grovemusic.com; assessed 30 March 2005.

Ormandy, Eugene. “Eugene Ormandy’s statement on David Amram’s “Trail of Beauty.” Internet. Available from

http://www.fmp.com/amram.classical-reviews/conversations-html; assessed 23

April 2005.

Rosenberg, Donald. “Lifelong Multiculturalist Naturally Multimusical. The Plain Dealer (Cleveland, Ohio) 2 February 1997. Internet. Available from http://www.fmp.com/amram/reviews-conversations.html; assessed 22 April 2005. 
Rush, Diane Samms. "Son of the South, Amram celebrates his roots.” Witchita Eagle, August 1999. Internet. Available from http://www.fmp.com/amram.southern-stories-krreview.html; assessed 23 April 2005.

Schiff, David. “Carter, Elliot.” Grove Music Online. Available from http://grovemusic.com; assessed 22 April 2005.

Skelly, Richard. "From the program of the 25th annual New Jersey Folk Festival.” 1998. Internet. Available from http://www.fmp.com/amram/inthenews.html; assessed 25 May 2005.

Turner, David. “Johnny Jazz Seed,” Internet. Available from http://www.fmp.com/amram/jazz.lamont.html; assessed 22 April 2005.

Webster, Daniel. “Amram’s work on Indians puts cap on Bicentennial,” Philadelphia Inquirer, 5 March, 1977. Internet. Available from http://www.fmp.com/amram.classicalreviews/trail-of-beauty-1.html; assessed 22 April 2005.

\section{Discographies}

Amram, David. Shakespearean Concerto; Piano Sonata. Notes by the composer. WLP 9470, New York City; Washington: 1966. LP recording.

. David Amram: An American Original. Produced by David Amram and Stephen J. Epstein. Newport Classic. Notes by David Amram. 1993. Compact disc.

Atlanta Chamber Players. Conversations: A $20^{\text {th }}$ Anniversary Salute to American Composers. Produced by Paula Peace. 66:47 min. ACA Digital Recording, CM 20038, 1996. Compact Disc.

Boulton, Kenneth. Elie Siegmeister: Piano Music, Vol. 1. 73:51 min. Naxos 8.559020, 1999. Compact Disc.

Lewin, Michael. Charles Tomlinson Griffes: Complete Piano Works, Volume 1. Notes by Michael Lewin. 66:45 min, Naxos of America, Inc., Naxos 8.559023, 1999. Compact Disc.

Meister, Barbara. Twentieth-Century American Music. Produced and Engineered by Joseph Patrych. 66:34 min., Centaur Records, Inc., CRC 2622, 2003. Compact Disc. 
Monk, Thelonius. Monk at Newport. Produced by Orrin Keepnews. Notes by Orrin and Peter Keepnews. 122:13 min. SONY Music Entertainment, Inc., 2002. Compact Disc. 


\section{APPENDIX A}

\section{Telephone Interview with David Amram}

\section{Interviewed by Amanda Yuet Hwa Lee on April 5, 2005 Edited by David Amram on April 28, 2006}

Lee: Would you be able to give me an approximate date of completion of the Piano Sonata?

Amram: $\quad$ I completed it just before the performance by Andrew Heath in the Fall of 1960. The world premiere took place in 1960 at the Metropolitan Museum of Arts small concert hall, Grace Rainey Rogers Auditorium. I wrote it during the summer of 1960 in Ocean Beach. A man named Dr. Jules Eskie, who was a dentist, was nice enough to let me borrow his small upright piano, which he had at the beach, and I used that piano. I sat there all summer working like a fiend and completed the piece

Lee: $\quad$ Did you have any other sonata in mind which served as a model while you were working on the Sonata for Piano?

Amram: $\quad$ No, not at all.

Lee: $\quad$ There are some very strong jazz elements found especially in the sonata itself. Are there any specific origins that you were aware of with any of these figures? Are they mostly originated from your jazz background?

Amram: $\quad$ Well, a lot of the harmonies that I used and the idea of the harmonic styles were very much based upon the extraordinary and creative sophisticated music that was part of the musical language of the jazz community, which I was also very much a part of, having played with Charles Mingus, Dizzy Gillespie, Thelonious Monk and Charlie Parker. A lot of those wonderful jazz artists who were really, I always thought, just like the great classical composers of the past. Every note counted, and was there for a reason.

They elevated their music to a high artistic level that superseded their role as entertainers to play background music while people bought drinks. They were serious and gifted creators with enormously high standards.

Hindemith always talked to his students about Gebrauchmusik which meant music that serves a useful function for the specific situation for 
which it was created, and therefore it was honorable to think of a composer as a master craftsman, whatever the genre or the nature of the task the composer was given. It was the composer's job to bring high standards and artistic excellence to every situation.

But at the same time, this same music should be of such high quality that it could be absolute music or art music as well, standing on its own, and outlive the limitations of the situation for which it was created.

This often made me think of my favorite scores by Stravinsky, which were his great ballet scores, written at the request of the choreographer Diagilev, which proved to be great concert music as well.

The same was true of the Brandenburg Concertos [which] were gebrauchmusik, commissioned by the Margrave of Brandenburg for dinner music (called tafle musik in German).

Neither Stravinsky nor Bach had the value of their work diminished by the expectations of their employers, and both created masterpieces that exceeded the demands put upon them.

Like Pierre Boulez during his youth, I worked as composer in the theater, writing incidental music for dramatic plays, which was certainly gebrauchmusik. But I always tried to write music that would outlast the particular productions the music was written for. I did scores for 29 plays by Shakespeare, and loved doing it, and took it very seriously. I used a short melody I wrote for a 1957 production of Macbeth for Joe Papp's Free Shakespeare in the Park, and chose this melody for the theme of the last movement of the Piano Sonata.

When the young American pianist Andrew Heath asked me to compose a piece for him, I was thrilled to be commissioned to write a piece of absolute music. And I felt free to use some of the elements that I loved in the music I was surrounded by, which was seldom ever written down in a formal European compositional style, but rather improvised by genius musicians on the spot, to be heard one time only, unless someone recorded it at that moment.

So for the Piano Sonata, I wrote an old-fashioned art for art's sake piece. And I always said that, especially in the case of the first movement, and in much of the second movement, and in one of the variations in the third movement, I used a lot of the harmonic procedures, phrasing, and polyrhythms that were part of the jazz world's aesthetic.

The vernacular used in the 50's to describe the embellishments of the jazz masters was the expression "choice notes." During that time, this kind of 
music in the classical musical establishment wasn't even considered to be of any importance. Most conservatories music didn't even teach the music of George Gershwin as being worthy of study.

Rhapsody in Blue, the Concerto in F, An American in Paris, and Porgy and Bess, were usually never thought of as being classical compositions of any substance, which I thought was almost clinically insane, since it seemed that among most musicians and millions of people around the world, that anyone who was not hard of hearing would realize that these were magnificent as well as highly original works of music.

The fact that Gershwin was also a genius songwriter and immensely popular seemed to close many critic's minds and ears and heart to the extent that they apparently could not hear that he was creating a new language, based on folk roots of his environment upon which he based his stunning compositions, in the same way that Tchaikovsky, Bartok, Dvorak, and many other European masters did as well.

And I also felt that the harmonic structure of Thelonious Monk's music, and the work of Dizzy Gillespie and Charlie Parker, all three of whom I was fortunate enough to have met and played with, (Dizzy Gillespie in 1951, Charlie Parker in 1952, and Monk in 1955) all achieved the same result in their life's work.

All three had an extraordinary knowledge and ability to expand upon traditional harmony in a whole new way. And I thought, how can I not include something that I love so much, now that I am composing a piano sonata. I tried my own way to honor these brilliant and innovative musicians, and the cultures they came from, which through years of association had become part of my own cultural experience. I tried to create a traditional sonata using my own language, rather than trying to imitate what Arnold Schoenberg, or Stockhausen, or what the Avant Garde or Chance composers were doing. They had already done that.

I always thought that the composer's job was to write the most perfect, gorgeous well crafted music possible, and then hopefully there would be something worthy of playing for the musicians or singers who performed it.

I hoped then, in 1960, when I was writing the sonata, as I do now in 2005 as we speak, that after any musician started playing any music of mine a few times, suddenly they would like it more, not less, and get a feeling that is so strong, it would move them to want to perform it as a way of expressing their own artistry. And then in the process of absorbing that feeling from what the notes on the paper gave to them when they were playing them, they would begin making them into their own. This special 
personal feeling of involvement would then transmit to listeners a whole high aesthetic level of expression, which would be a positive experience for all involved, and at least for a moment make the world a more beautiful place.

I couldn't have imagined back then, any more than I can imagine now, that any composer whose work has lasted didn't also feel that way. Since I wasn't aligned with any institution, I never had to write any piece in any way other than that what I felt in my heart, that's what I did when I wrote the sonata, and that's what I've done in the forty-five years since then, and that's what I always hope to do.

And since I am a stickler for structure and detail, my music has never been dismissed as be just endless torrents of gushing soporific mood music, elevator music or "fusion." The very art of composing is fusing together elements of sounds, styles, and instruments. So the whole idea of defining the incorporation of "ethnic" music as being multi-cultural or nationalistic is ridiculous (since every human who ever was born reflects a certain ethnicity, and brings that with them into the larger arena of the society they live in).

I was honored recently by the Milken Foundation when they recorded excerpts from my opera of the Holocaust, The Final Ingredient. They also recorded my symphony Songs of the Soul and excerpts of my Sacred Service which I wrote the same summer I was finishing the Piano Sonata. The Sacred Service drew on my musical heritage of various forms of traditional and Middle Eastern music setting Hebrew prayers to music for chorus, organ, and solo tenor voice. The Piano Sonata, which I was composing at the same time drew on other experiences from my life. I had no problem or sense of conflict about this at all.

During that summer of 1960, I was interviewed by the Provincetown Review about my music, and asked to describe my Piano Sonata.

When I told them what I was doing and how I was doing it, I was asked "When did you change from being a serial composer to your present way of composing?"

I said I never was a serial composer.

They said "How can you be in New York and function in the music world all this time, and still write the kind of music and live the way you do, and hope to have any kind of a career without being aligned with any university or school of composition?" 
I told them that I didn't think that being a composer had anything to do with having a career. It had to do with finding a way to pay the rent and still write better and better music your whole life.

I said that I loved the music of Mozart, Beethoven, Berlioz, Bartok, and Charlie Parker, and that their lasting music was the level that I was striving to reach and expand upon during my lifetime, and that this had nothing to do with having a career. It had to do with creating work of enduring value.

"You mean you always know what you were doing"? I was asked.

"All I know is that I've done the best I can so far, and that I'll continue to try to do it better. And I never dare tell anybody else how to write their music, except to say that it should have a beginning, a middle, and an end. And the more specific and clear it is, to all performers, to the singer, to the conductor, to the instrumentalist, the better chance it's going to have to retain value in the long run. And it also has to have some true musical purity and well thought out content. And that's something that's a musical, spiritual, cultural, magical thing that you can't put in a textbook, and you can't teach." The Provincetown Review stopped being published many years ago, but I still believe and try to put into practice everything that I said forty five years ago.

Since I was a kid, I have been influenced by both of my uncles who spent much of their lives with Native American people, and always tried to apply the tenets of the Navajo Prayer of the Twelfth Night, which celebrates the beauty which surrounds us every day.

In 1976, I wrote a piece for the Philadelphia Orchestra, Trail of Beauty for mezzo soprano, solo oboe, and orchestra, based on that beautiful prayer which includes "...beauty all around us, beauty before us, beauty below us, on the trail of beauty, therefore I am."

Most people of any culture that survives the test of time believe that we are surrounded by beauty, and that we can enrich ourselves by revering what's already here which mother nature provides us with. I think even before the Renaissance started, a lot of painters, poets, composers, and artists of all kinds felt this way, and felt that part of their job was to celebrate the humanity of those people who often had no voice, but who had so much to say.

For hundreds of years, the great classical traditions of art created by many nations of Europe have flourished. Even when the creative people were supported and told what to do by the royalty of the day, these artists always walked that trail of beauty in their work, and appreciated the folk 
cultures that surrounded them, and often enabled them in their own work. And they managed to include these elements in their work.

Then somehow in 20th century, when the artists themselves became institutionalized, they were forced to work within the academic framework, where the personal relationship between the artist and society was replaced by trying to make composers an extinct species, now forced to teach music like Real Estate taxes, or present new music in a completive way, being put in a contest to be judged against the work of other composers in other universities, like the Athletic Department where you train what is supposed to be a celebration of sportsmanship, and turn it into a situation of always being in competition with someone else, rather than celebrating creativity and bringing together the old and the new, whether in an artistic or an athletic collaboration.

I never felt it was fair to put a composer in the same situation as the head of an athletic department, having their work judged in the same fashion as a football coach's work is judged.

Composition isn't about winning or losing. It is about creation of new music, to enhance the literature.

I realize I have strayed from your original question, but on behalf of all my colleagues who are composers and work in universities, and who want to have their rightful place as artists restored within the framework of an educational situation, and who want their music to be a vital part of the society, rather than a tax write off, I wanted to make these comments.

Lee: $\quad$ I found that a transposition of either a major/minor 2nd is often seen in both of the first and second movements whenever a theme is restated. Is that a compositional technique that you favor?

Amram: I did that because it felt right to do at that moment during the recapitulation, even though I realized it would make it harder for the pianist to memorize. In the case of the piano, transposing long sequences forces you to memorize anew all the keyboard patterns, which, when transposed are the exact same material, but are now in different positions on the piano.

I was very much influenced by Brahms who sometimes did that. Brahms would sometimes have a recapitulation where the same material was restated in a different key, and therefore required relearning the same material. This always requires the soloist not to confuse the second time around the material has been played already, and has to always be alert so as not get it confused with the first one, which they have already learned 
in a different key. I was always impressed by how fine pianists can handle that.

I thought, well, I guess Brahms must have done that in his symphonies because each key has its own special characteristics, and frankly I have no idea exactly what those characteristics are, but I can feel them in Brahms' music, and I felt these same mysterious emotional differences while composing the sonata, when I decided to have the recapitulation in a different key.

I also thought at the time that it would be more interesting for the performer as well as for the listener. Of course [it] is harder to memorize than having it restated in the same key, and I realize that for a pianist or practically any other instrumentalist, that after you have retained certain patterns and suddenly they have to do them a second time differently, there is always the possibility of forgetting and sliding into the wrong pattern, as if you were in the Asian Restaurant, where there is column one and column two, and you forgot which column you are in.

I think for the listeners, somehow, whether or not they have perfect pitch and even know that the recapitulation is in a different key, the same thing definitely sounds different in different keys, and certainly on the piano. So I just thought that it would be interesting to do this in the sonata. I remember thinking about it at the time, and of course I ultimately did it because it felt right to do.

I composed a Symphony called Kokopelli which was recorded by the Nashville Symphony, and I have a huge recapitulation which I put into a different key. I just felt somehow when the recapitulation was played in a different key, it seemed to make it more intense and the musicians played it differently. But ...ultimately it was a choice I made that was emotionally driven rather than intellectual. It didn't come from any theoretical basis of having to do it. It was just something I did instinctively because it felt more interesting and meaningful.

It was Brahms who inspired me to do that. When, as a teenager sixty years ago, I first heard a symphony where Brahms did this, I felt something I had never felt before. I always remember that feeling...how it gave the restatement of the theme a wondrous glow.

Lee: $\quad$ Each movement ends with a nostalgia-like character. Could you elaborate your thinking on that?

Amram: $\quad$ There is so much complex stuff to play in the first movement and so much for audience to hear for the first time that I wrote a simple lyrical second 
movement for contrast, which would also give the pianist a change to make the piano sing and use every color available. As you know, the first movement ends with a pizzicato effect, leaving the listener wanting more and wondering what will happen next.

I always like the idea of the first movement ending in suspenseful way, leading into the second movement. I wanted the second movement be touching and sad, leading into the third movement, and then to have the piece end with enough space for the listener to hear it in their mind again, like the ending of the first movement of Schubert's Unfinished Symphony, rather than in a crashing bashing smashing grand finale.

I have three other pieces that don't end triumphantly, the Dirge and Variations composed for the Marlboro Trio, my symphony Trail of Beauty, where the haunting beginning returns at the end, and it is a very powerful and effective ending for this particular piece. The third work which ends softly is the end of my opera Twelfth Night, with Feste singing the simple touching song The Wind and the Rain, which is the way Shakespeare himself ended the play.

But generally speaking, I took the advice of the great oboist of the Philadelphia Orchestra, Marcel Tabuteau, in whose memory Trail of Beauty was dedicated. Tabuteau was a friend of my father's and in 1945, when I was fourteen years old, Tabuteau took me out for a meal after a concert with the Philadelphia Orchestra in Washington D.C., and told me, "If you are a composer, you have to end your pieces with a 'bang,'with trombones, timpani, and cymbal crashes. People like that. If you end with a soft ending, it is very hard. We like more subtle endings as opposed to what sounds like a bomb attack, because we're musicians, but the public wants to know that is over."

I think while I have some other pieces that end slowly and softly, there are only these three which end in a kind of a whisper. And the Piano Sonata of course is the first time I ever did this and I would never change it.

Lee: $\quad$ When I listened to the Conversations, I noticed the tempo changes in Variation V of the third movement in the Conversations compared to the Variation V of the third movement in the Piano Sonata. Did the arrangement for the ensemble playing change some of your tempo decisions? For instance, in Variation $\mathrm{V}$ of the sonata was 126 beats per minute but for the Conversations, it was 96 beats per minute.

Amram: Well, one of the problems that I encountered in 1960s was that most pianists who played the sonata were fabulous players, but they have no idea of the language I was using. To them, it probably felt as if they were 
playing music of the Innuit or Northwest Territories Eskimo people, which I have heard, and which is extraordinary. In the Piano Sonata of course, I was using indigenous music from the world of what was then contemporary jazz, but in the 1960s there was still no concept of what this music was about and the nuances and subtleties of how it was constructed.

Because there was no recognition of the enduring value and historic relationships that we now call the world music and European classical music have shared since Mozart wrote his Rondo alla Turque, most serious classical pianists were blocked off to what the language of Charles Parker, Thelonious Monk, and these other amazing musicians were adding to the world of music as a whole. So a lot of phrases and rhythms, even though they were notated exactly, were very hard for many pianists to play, even though there were some great performers who played it magnificently. Richard Goode played it at the Town Hall in 1962. He played it fantastically. Mitchell Andrews made a terrific recording of it in 1967. But most people who played it, who were really good players didn't understand the language. Today, in 2005, the younger players all do.

If I could play well enough some Pierre Boulez piano music, I would have someone help me to understand what it was about, because he uses a language that's alien to me. It doesn't mean I don't think [it] is good. I would have difficulty trying to put his ideas together and then make it aesthetic by adding any personal touches. I would start out by learning to play one measure correctly, which I wish I could do. Boulez himself can, and so can some other fabulous pianists. That wasn't always the case.

The language of my piece, while based on the vernacular, was so far [foreign] to most pianists at that time, that [it] often sounded unstructured and didn't make sense. I loved what was in the sonata so much and I figured, well, maybe I would orchestrate parts of it, use some different instruments, and some pianists, hearing the new pieces would discover this sonata and see what it was really all about. So when I redid the second movement, Lullaby, and made it into a chamber music version in Conversations for Flute, Violin, Viola, Cello and Piano, 98\% of the material was drawn from the Piano Sonata. I put in a little introduction at the beginning and some of the slight changes that I made, a lot of pianists think, “Oh, my goodness!” And suddenly they will be able to hear it even though it was the same notes. So rather than making a piano reduction, in order for that piece to become popular, I said, "I will do the same thing as Mussorgsky's Pictures at An Exhibition, or what Beethoven did with the Chorale Fantasy." And I just put in a different version and maybe some of them will get it. I even have a wind symphony version that is called the Andante and Variations on a theme of Macbeth for Wind Symphony Orchestra. And I orchestrated those two movements, and that is the only piece that I have done that way. And then I have one called Across the 
Wide Missouri, I took a big part of the first movement of the Piano Sonata, and the Overture turned out to be a nice piece that gets played a lot. I am actually happy [with] what I did because in all these different versions, the same notes that I had in the sonata, the harmony, the counterpoint, and the rhythms all come across...

I always believe that some day, pianists would discover the piece, and not have me be around to explain anything to them. Sometimes it takes a long time. Many young pianists like yourself now can see how I combined the same languages of neo-classical music, with a $19^{\text {th }}$ century style and jazz elements in the sonata. And now you see what people being interested in different cultures, all having beautiful contributions, some undiscovered, and I don't think that [it] is necessary to do that at all to write good music.

I think you could do anything. Anyway, there is no rule except the one thing that I used to explain, why the music of Charlie Parker, Dizzie Gillespie, Monk, [along with] Middle Eastern, American Indian Music, Asian Music, and symphony music always has appealed to me which is very simply: purity of intent and an exclusive choice of notes. If they put up a tombstone for me at that big musical cemetery, I often would say, "Purity of Intent, and an Exclusive Choice of Notes." That, to me, is the common thing that bonds all music of lasting value. That's what I always try and that's what I have always been attracted to.

I learned a 10 second musical snippet in Pakistan in 1978.

The fragment of the melody is based on a five note raga called Bopahli, and utilizes a traditional ten beat pattern called dindal. I wrote a whole two hour ballet score called Chakra, based on this tiny pattern, which became the leitmotif for the entire ballet. During rehearsals of the ballet, I learned another traditional piece from musicians from Madras, and spent endless late night-early morning hours learning how to write down this traditional piece, as if I were a student in kindergarten. I used this simple old melody, within its extraordinary rhythmic structure, as a point of departure for the ballet score.

In 1992, I composed an overture, Chakra, as the first movement of a three part orchestral work called Celebration.

Whenever I use anything that is folklore, as in the case of Chakra, I ALWAYS put the name of what the source is and who taught it to me, and put it in the score and parts, even if I just used two measures of the rhythm or four measures of an old tune.

Even if it is technically what is called public domain, and the copyright law said is not necessary to do this, the law of decency always [makes you] 
thank those who gave you a gift. And by doing that, you remain honorable. You will also be someone that would continue to be able to share what you know, and receive [the] gift of other people's knowledge, and see that you are interested in honoring something. And also hopefully be able to represent correctly, rather than stealing and misrepresenting [it].

Lee: $\quad$ Did you have a chance to dedicate this sonata to anyone?

Amram: If it had been, I would have put it in the music.

Lee: Which of your composition teachers did you find most influential to your writing?

Amram: Well, I took a few lessons with a wonderful composer named Charles Mills. I took five lessons with him in 1955. And I studied at the Manhattan School of Music with Vittorio Giannini, who is terrific; and a wonderful teacher named Ulehla Ludmila in 1955-56. She was a twelvetone composer, and a fabulous musician, and very supportive. All three of those people, aside from being grounded in the classical European tradition of species counterpoint, stressed studying orchestration, and harmony.

When I was fourteen years old, I studied one summer with a man named Wendell Margrave, when I lived in Washington DC. He was an organist who loved Bach.

All four of these teachers knew that if you could understand Bach, you had the basis for doing anything in music. Giannini told me that when he met Richard Strauss, he said Richard Strauss told him that essentially everything Strauss himself composed was four-part counterpoint, and sometimes five at the most. And that everything that Strauss himself composed was based on that. Giannini told us that he just sat there, absorbing everything Richard Strauss was saying, and then applied that same idea into his own music. And that by studying Bach's work, we could find our own way.

Wendell Margrave, Charles Mills, Ludmila Uhlela, and Vitorio Gianinni were each totally different from one another. They each had their own way but all four were grounded in tradition and had a sincere way of approaching music in a pure and individual way. They were and remain inspiring to me every day. 
Lee: $\quad$ Have you thought of writing another sonata for piano?

Amram: $\quad$ Yes, at this point, I would love to. I have [had] a bunch of pianists who have asked me to do it. I would love to do it, and I am sure that I will. The pianists today are so incredible, not just technically, but also musically, and [they] appreciate the kind of things that I am interested in. If you have seen the score for my Native American Portraits, a threemovement piece for violin, piano, [and] percussion, using American Indian motifs from the Cheyenne, Seneca, and Zuni nations which I learned from playing with the American Indians, I was able to use the piano in a whole different way.

Naxos has just released excerpts from it on an all-Amram CD sponsored by the Milken Foundation. When I was recently interviewed, and asked what it felt like to have work done nearly a half a century ago, finally be recorded or re-discovered, I said, "Well, Moses was in the desert for 40 years, so I am really right on schedule.”

I believe that someday the Piano Sonata will find its place in the repertoire. And I am so happy because I like it just as much as when I wrote it 45 years ago.

Lee: $\quad$ I performed the first movement of the piano sonata at the Las Vegas Music Festival in 2004. I also played it for Mr. Jerome Lowenthal at his masterclass, and he said, “It sounded just like David Amram.”

Amram: So, Jerome heard the piece? Isn't that something? I have known Jerome for so long. Sometimes it takes several generations before musicians can hear a style that resonates and makes them know who the composer is. So for a great player like Jerome to be able to know the sonata was composed by me after hearing a bit of it is a real compliment.

It was the piano sonata that attracted the attention and support of my music by the great Rudolf Serkin. In the summer of 1960, I was invited to visit the Marlboro Music Festival, where I was asked to be the best man in a friend's wedding. When the bridegroom, Dan Cowan introduced me to Serkin who said to me, and I quote, "Have you written anything for us poor pianists?” I almost fainted. Rudolf Serkin was like a hero of mine. I said to him that I had just finished a piano sonata and he asked me to send him the music.

A few months later, after it was completed and premiered, I sent him the score, and to my amazement, he invited me to be the composer-inresidence at the Marlboro festival the next year, the summer of 1961 . And 
I was astounded. I felt that if he appreciated what I was doing, nothing else really mattered. That in itself was enough to keep me going. I think there are so many composers that we have all over the world whose music deserves to get played and who need support from their elders.

I always try to encourage other composers, writers, and performers to dare to be creative and to follow their hearts. I think that is very important for them to know that it might take a long long time to have their work appreciated, but to quote the great English poet, John Keats, "A thing of beauty is a joy forever."

We are all aware of the TV program where you see Donald Trump insulting and abusing people, and where the highlight of the show is when young hopefuls are told, “You're fired!” This negative way of dealing with people may be a path towards becoming a real estate tycoon or a prison warden in a maximum security facility.

I don't think that any of us, whether we teach in a conservatory of music or perform for people not conversant with sophisticated music built to last, should ever allow ourselves to succumb to wretched and selfish abusive behavior towards anyone.

I think that we in the arts are telling the world, you are hired, join us, be positive, be creative! Don't give up, just work hard. I think that is really important. 


\section{APPENDIX B}

\section{Published Compositions by David Amram ${ }^{129}$}

\section{ORCHESTRA}

\section{ACROSS THE WIDE MISSOURI}

(ca. 10 minutes)

2 (Picc), 2 (EH), 2 (Bc1), 22211 Perc(3), Str

\section{AMERICAN DANCE SUITE}

(ca. 19.5 minutes)

2 (Picc) 2 (EH) 224231 T, Perc (3), Hp, Str

\section{AUTOBIOGRAPHY FOR STRINGS}

(8 minutes)

String Orchestra

\section{BASSOON CONCERTO}

(22 minutes)

Bsn Solo, 33324331 T, Perc, Pf, Cel, Hp, Str

\section{BLUES FOR STRING ORCHESTRA (Second Movement of American Dance suite) \\ (ca. 5 minutes)}

\section{CONCERTO FOR HORN AND ORCHESTRA}

(12 minutes)

Horn Solo, 33334331 T, Perc (4), Pf, Hp, Str

Same for Horn and Piano

\section{ELEGY}

(12 minutes) (P66423)

Violin Solo, 22 (EH), 2 (Bcl), 4 (Cbsn), 4331 T, Perc (3), Hp, Str

\section{EN MEMORIA DE CHANO POZO}

(ca. 10 minutes)

Jazz Trio and Orchestra

Fl, Elec. Bass, Pf, Soli 2222 4231, Perc (4), Str

\footnotetext{
${ }^{129}$ David Amram, “Classical Compositions by David Amram,” 11 April 2006
}

$<$ http://www.davidamram.com/classical_compositions.html>. 


\section{KOKOPELLI, A SYMPHONY IN THREE MOVEMENTS FOR ORCHESTRA}

\section{HONOR SONG}

(ca. 17 minutes)

Vc Solo, 2 (Picc), 2 (EH), 2 (Bcl)2 2220 Perc (4), Str

\section{ODE TO LORD BUCKLEY}

(18 minutes)

Concerto for Alto Saxophone and Orchestra

A Sax Solo, 22222221 T, Perc, Str

Same for Alto Saxophone and Piano

\section{SONGS OF THE SOUL (Shiray Neshama)}

(ca. 15 minutes)

2\(Picc), 2 (EH), 224221 Perc (3), Str

\section{THE TRAIL OF BEAUTY}

(25 minutes)

Mezzo-Soprano, Oboe Solo, 21(EH), 334231 T, Perc, Hp, Str

Text: Selections from Navajo Prayer, Iroquois Constitution

Song of the Sky Loom, and Chief Seattle's Speech about the meaning of Land to Native American People.

Same for Mezzo-Soprano, Oboe and Piano

\section{TRAVELS FOR TRUMPET AND ORCHESTRA}

(ca. 15 minutes)

Trp Solo, 2 (Picc), 2 (EH), 224220 T, Perc (3), Str

Same for Trumpet and Piano

\section{TRIPLE CONCERTO}

(25 minutes)

Soli: Woodwind Quintet, Brass Quintet, Jazz Quintet

Orchestra: 2 (Picc), 2 (EH), 2 (Bcl), 2 (Cbsn), 2220 T, Perc (5), Hp.

Cel, Str

\section{VIOLIN CONCERTO}

(22 minutes)

Violin Solo, 33334331 T, Perc (3), Str

\section{CHAMBER ORCHESTRA}

\section{THE AMERICAN BELL}

(45 minutes)

Narrator, 11112111 Str

Text: Archibald MacLeish 


\author{
PEER GYNT \\ Incidental Music to the play by Ibsen \\ 11111000 Perc (2), Vn, 3 Vas \\ SHAKESPEAREAN CONCERTO \\ (22 minutes) \\ Oboe, 2 Horns, Strings \\ THEME AND VARIATIONS ON RED RIVER \\ VALLEY \\ (ca. 15 minutes) \\ Flute Solo and Strings \\ Same for Flute and Piano
A LITTLE REBELLION - THOMAS JEFFERSON
Narrator, String Orchestra, Woodwind Quintet
and Percussion

\title{
BAND
}

\author{
ANDANTE AND VARIATIONS ON A THEME \\ FROM MACBETH \\ (ca. 15 minutes) \\ 3 (Picc), 3(EH), 7 (Eb, Alto, Bcl) 23 Saxes 4441 Euphonium, T \\ Perc (7) \\ CAJUN (Fourth Movement of American Dance Suite) \\ (ca. 8 minutes) \\ 4 (Picc), 4 (EH), 4 (Bc1), 44431 Perc (3)

\section{CONCERTO FOR HORN AND WIND SYMPHONY} \\ ORCHESTRA \\ (12 minutes) \\ Horn Solo, 4 (Picc), 4 (EH), 4 (Bcl), 4 (Cbsn), 4441 T, Perc \\ Hp, Pf \\ The American Wind Symphony Editions

\section{EN MEMORIA DE CHANO POZO} \\ (ca. 10 minutes) \\ Jazz Trio and Band \\ 3 (Picc), 3 (EH), 7 (Eb, Alto, Bcl, Cbcl), 23 Saxes \\ 4441 Euphonium, Perc (4)
}




\section{FANFARE FOR SEVENTEEN BRASS AND \\ PERCUSSION}

(6 minutes)

6 Hrns, 6 Trps, 4 Trbs, Tba, Perc (4)

\section{KING LEAR VARIATIONS}

(15 minutes)

4 (2 Picc), 4 (EH), 4 (2Bcl), 4 (Cbsn), 6441 T, Perc (4), Pf

The American Wind Symphony Editions

\section{ODE TO LORD BUCKLEY}

(18 minutes)

A Sax Solo, 3 (Picc), 3 (EH), 7 (Eb, Alto, Bcl, Cbc1) 23 Saxes

4441 Euphonium, Perc (6)

\section{OVERTURE FOR BRASS AND PERCUSSION}

(2.5 minutes)

6 Hrns, 6 Trps, 4 Trbs, Tba, T, Perc (4)

\section{RONDO ALLA TURCA}

(10.5 minutes)

(Arranged for Symphonic Band from last movement of Triple Concerto)

33723 Saxes, 4441 Euphonium (Bar Hrn), T, Perc (7),

Cel, Fl Solo, String Bass, Jazz Drums

\section{INSTRUMENTAL \& CHAMBER MUSIC}

\section{BLUES AND VARIATIONS FOR MONK}

(ca. 6 minutes)

Horn Solo

\section{CONVERSATIONS}

(ca. 20 minutes)

Set of Parts

Flute, Violin, Viola, Violoncello, and Piano

\section{DIRGE AND VARIATIONS}

(14 minutes)

Violin, Violoncello, and Piano

\section{DISCUSSIONS}

(10 minutes) 
Flute, Violoncello, Percussion (2 players), Piano

\section{DUETS}

(ca. 12 minutes)

2 Flutes

FANFARE AND PROCESSIONAL

(6 minutes)

Brass Quintet

\section{LANDSCAPES}

(10 minutes)

Percussion Quartet

NATIVE AMERICAN PORTRAITS

(12 minutes)

Vn, Pf, Perc (1)

OVERTURE AND ALLEGRO

(5 minutes)

Flute Solo

\section{PORTRAITS}

(10 minutes)

Violin, Viola, Violoncello, Piano

\section{QUINTET FOR WINDS}

(19 minutes)

Fl, Ob, Cl, Hrn, Bsn

SONATA FOR VIOLIN AND PIANO

(18 minutes)

\section{STRING QUARTET}

(20 minutes)

\section{SUMMERNIGHT'S DREAM}

(20 minutes)

Incidental Music

Trp, Ob, Bsn, Vn, Vc, Cemb (Pf), Perc

THREE SONGS FOR MARLBORO

(12 minutes)

Horn and Violoncello 


\section{TRIO}

(14 minutes)

Tenor Saxophone, Horn and Bassoon

\section{ZOHAR}

(5 minutes)

Alto Recorder (Flute)

TROMBONE ALONE

Solo Trombone

\section{PIANO}

SONATA FOR PIANO

(18 minutes)

\section{VOCAL}

\section{FIVE SHAKESPEARE SONGS}

(12 minutes)

From the opera "Twelfth Night"

Voice and Piano

\section{FOUR SHAKESPEARE SONGS}

High Voice and Piano

1. Who is Sylvia? (from "Two Gentlemen of Verona")

2. Take, Oh Take Those Lips Away (from "Measure for Measure")

3. Lullaby (The Spotted Snake) (from "A Midsummer Night's Dream")

4. Ophelia's Song (from "Hamlet") (unaccompanied voice)

\section{THREE SHAKESPEARE SONGS}

Bass (Baritone) Voice and Piano

1. Blow, Blow Thou Winter Wind (from "As You Like It")

2. Malvolio's Aria (from "Twelfth Night")

3. Fool's Song (from "King Lear") 


\section{THREE SONGS FOR AMERICA}

(8.5 minutes)

Bass Voice, Wind Quintet and String Quintet

Texts: John F. Kennedy, Martin Luther King, Jr. and

Robert F. Kennedy

Vocal Score

\section{CHORAL}

BY THE RIVERS OF BABYLON

(5 minutes)

Soprano Solo, SSAA a cappella

FRIDAY EVENING SERVICE (Shir L'Erev Shabbat)

(35 minutes)

Tenor Solo, SATB and Organ

THE PASSION OF JOSEF D.

Incidental Music to the play by Paddy Chayefsky

SATB Soli, SATB

\section{REJOICE IN THE LORD}

(ca. 2 minutes)

SATB a cappella

\section{THREE SONGS FOR YOUNG PEOPLE}

(ca. 5 minutes)

Voices (1-3 parts), Perc (4)

\section{TWO ANTHEMS}

(4 minutes)

Mixed Voices a cappella

\section{CHORUS AND ORCHESTRA}

\section{LET US REMEMBER}

Cantata (20 minutes)

SATB Soli, SATB, 22224220 T, Perc, Str

Text by Langston Hughes 


\section{A YEAR IN OUR LAND}

Cantata (25 minutes)

SATB Soli, SATB, 22222220 T,Perc(2), Pf, Str

Text: James Baldwin, John Dos Passos, Jack Kerouac, and others

\section{OPERA}

\section{THE FINAL INGREDIENT}

(57 minutes)

Opera in 1 Act adapted from the play by Reginald Rose 12 Soli, SATB, 22224230 T, Perc (2), Str

Libretto by Arnold Weinstein

\section{TWELFTH NIGHT}

Opera. Vocal Score

Text adapted from Shakespeare's play by Joseph Papp

Solo Voices and Chamber Orchestra

11112110 T, Perc (2), Str 